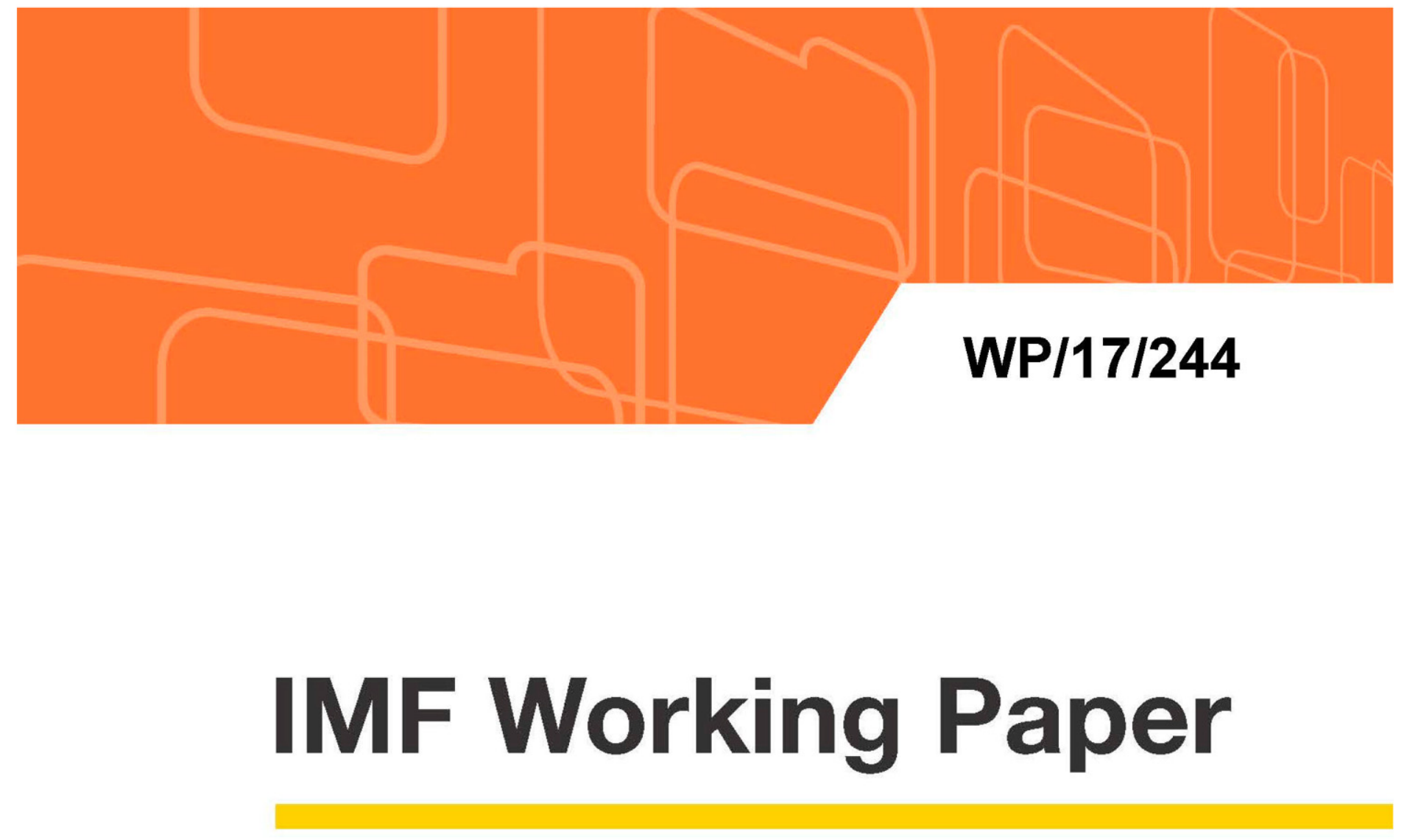

\title{
Hollowing Out: The Channels of Income Polarization in the United States
}

by Ali Alichi, Rodrigo Mariscal, Daniela Muhaj

IMF Working Papers describe research in progress by the author(s) and are published to elicit comments and to encourage debate. The views expressed in IMF Working Papers are those of the author(s) and do not necessarily represent the views of the IMF, its Executive Board, or IMF management.

I N T E R N A T I O N A L M O N E T A R Y F U N D 


\section{WP/17/244}

\section{IMF Working Paper}

\section{Hollowing Out: The Channels of Income Polarization in the United States}

by Ali Alichi, Rodrigo Mariscal, Daniela Muhaj

IMF Working Papers describe research in progress by the author(s) and are published to elicit comments and to encourage debate. The views expressed in IMF Working Papers are those of the author(s) and do not necessarily represent the views of the IMF, its Executive Board, or IMF management.

I N T E R N A T I O N A L M O N E T A R Y F U N D 


\title{
IMF Working Paper
}

Western Hemisphere Department

\author{
Hollowing Out: The Channels of Income Polarization in the United States ${ }^{1}$ \\ Prepared by Ali Alichi, Rodrigo Mariscal, Daniela Muhaj \\ Authorized for distribution by Nigel Chalk
}

November 2017

IMF Working Papers describe research in progress by the author(s) and are published to elicit comments and to encourage debate. The views expressed in IMF Working Papers are those of the author(s) and do not necessarily represent the views of the IMF, its Executive Board, or IMF management.

\begin{abstract}
Data show that middle-income households have continued to move down, and less so up, the income distribution in the United States since the 1970s - a phenomenon that is often referred to as the polarization or "hollowing out" of the income distribution. While the level of income polarization is generally lower in the richer states (defined as those with higher median household income levels), there have been wide variations in income polarization over time and across states. We develop two indices to measure income polarization, including a novel hollowing-out index. We also examine the proximate causes of income polarization, using an econometric analysis at both state and household levels. The results suggest that technology, measured by job routinization, and international trade, measured by job offshoring, can explain more than half of the rise in income polarization, with broadly equal contributions. Household characteristics, particularly better education, have had important countervailing effects on income polarization. Policies should continue promoting technological progress and international trade, but also recognize that these positive forces have important side-effects on the income distribution and household welfare that need to be understood and mitigated.
\end{abstract}

JEL Classification Numbers: D31; D63; E21; E25

Keywords: Middle Class; Middle-Income Class; Income Polarization; Hollowing Out; Inequality Author's E-Mail Address: aalichi@imf.org; rmariscalparedes@imf.org; dmuhaj@imf.org

\footnotetext{
${ }^{1}$ We are grateful to IMF seminar participants, Nigel Chalk, Stephan Danninger, Daniel Leigh, and Kory Kantenga for helpful comments and suggestions. All remaining errors are ours.
} 


\section{Table of Contents}

ABSTRACT

II. MEASURING INCOME POLARIZATION 7

A. Population-share Index $\underline{8}$

B. Income Hollowing-out Index $\underline{11}$

C. Comparison of the Polarization Indices $\underline{17}$

III. CHANNELS OF INCOME POLARIZATION $\underline{18}$

A. State-Level Regressions $\underline{22}$

B. Household-level Regressions $\underline{28}$

IV. CONCLUDING REMARKS $\underline{30}$

REFERENCES

FIGURES

1. Number of Households: Low, Middle and High ___ $\underline{3}$

2. United States: Evolution of Population Shares of Income Groups Across States ___ $\underline{4}$

3. State Real Median Income and Population Share by Class ___ $\underline{6}$

4. Wolfson's Polarization Index and Gini Coefficient, 1970-2016__

5. Population Share Index___ $\underline{9}$

6. Polarization by Employment/Employee Category __ 11

7. The Hollowing-Out Index__ 13

8. Changes in Lorenz Curves __ 14

9A Hollowing-out Index by State, 2016

9B. Hollowing-out Indices 1977-2016 ___ 17

10. Polarization Indices __ 18

11. State Real Median Income and Household Characteristics____ 19

12. Histograms: Offshorability and Routinizability Scores; and Offshoring and Routinization Levels__ 21

13. State Real Median Income and Employment Characteristics ___ 22

14A. Contributions to the Changes in Polarization Indices___ 26

Figure 14B. Contributions to the Changes in Polarization Indices: All Factors Except

Offshoring and Routinization __ 27

\section{TABLES}

1. State-level Regressions (System GMM): Polarization Indices __ _ 24

2. Household-level Regressions (OLS; Standardized Coefficients) __ $2 \underline{29}$

3. Household-level Regressions (Quantile Standardized Coefficients)___ $\underline{30}$

\section{APPENDICES}

I. Data___ $\underline{35}$

II. Income Polarization by State ___ 43

III. Wolfson's Index of Income Polarization__ $\underline{52}$

IV. State-Level Regression Tables and Contributions__

V. Household-level Regression Tables __ $\underline{62}$ 


\section{INTRODUCTION}

Prior work has documented the rise in income polarization at the national level in the U.S. since the 1970s, including some of its macroeconomic consequences, most notably lower aggregate consumption. Alichi et al. (2016) documented that, since the 1970s, the share of the middleincome households in the population - defined as households whose incomes are greater than 50 percent but smaller than 150 percent of the national median in each year-has decreased by more than 10 percentage points. Figure 1A shows an update of the trends from Alichi et al. (2016), adding in 2015 and 2016 data, corresponding to the most recent Current Population Surveys (CPS) published in 2016 and 2017, respectively. It shows that the two additional years have marginally improved income polarization in the U.S. with an uptick in the share of the middle-income households, largely mirrored by a downtick in the share of the low-income households.

Figure 1. Number of Households: Low, Middle and High

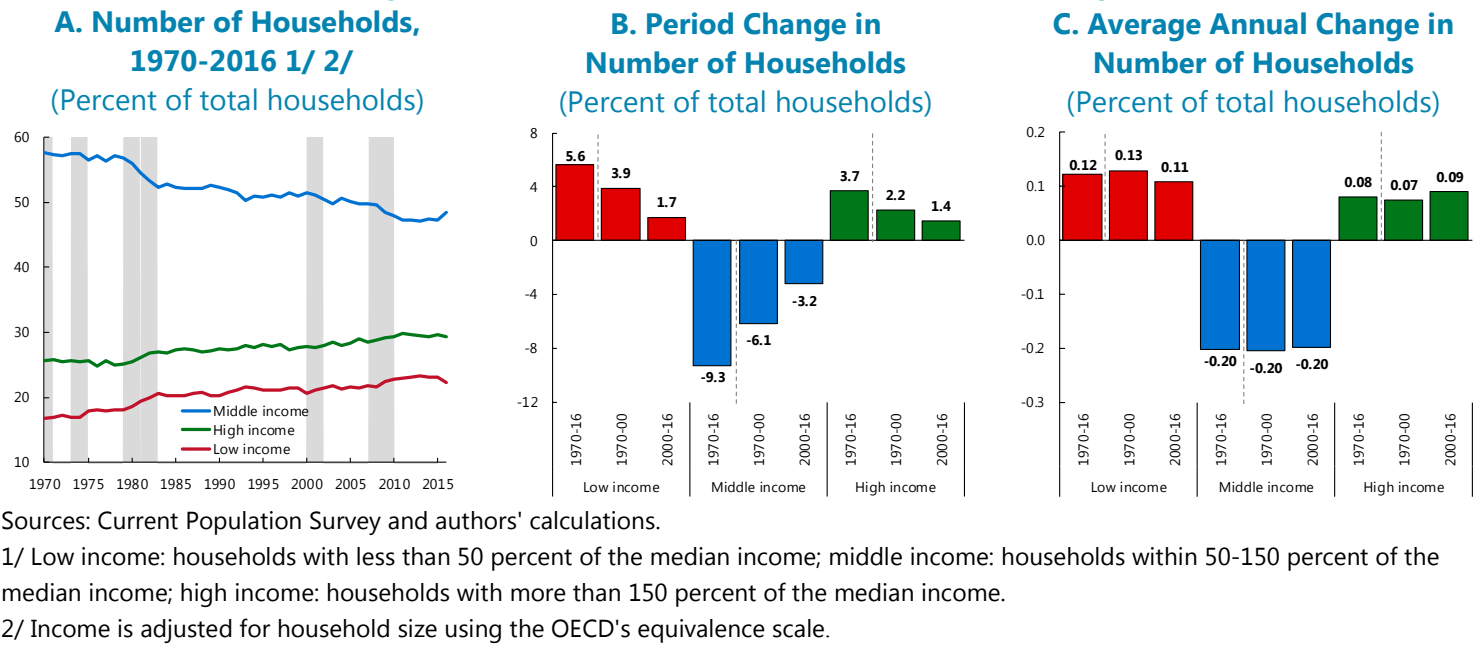

Figure 1B shows the period changes of the levels shown in Figure 1A for the full sample (19702016), as well as the pre- and post-2000 subsamples. During 1970-2016, about 9.3 percent of the U.S. households hollowed out of the middle-income class. Of these households, more than half (about 5.6 percentage points) joined the low-income ranks, earning less than 50 percent of the median income, and the rest (about 3.7 percentage points) joined the high-income ranks, earning more than 150 percent of the median. Figure 1B shows that for the pre- and post-2000 subsamples, as well, more than half of the households that hollowed out of the middle-income class, joined the low-income class, and less than half joined the high-income class. ${ }^{2}$

\footnotetext{
${ }^{2}$ In Figure 1 (A and B), The pre-2000 trends show stronger, but the post-2000 trends show milder downward polarization (i.e., from the middle- to low-income class) compared to Alichi and others (2016). This is due to two reasons. First, Figure 1 covers 1970-2016, whereas Alichi et al. (2016) covered 1970-2014. The two additional years (2015-2016) in the current study have observed an improvement in the national median income. Second, in Figure 1, the median income in each year is calculated based on the weighted income of households, using CPS's household population weights, while Alichi et al. (2016) used the unweighted household incomes to determine the median income in each year. Both studies, however, do use the household population weights in the calculation of populations of the low-, middle-, and high-income classes.
} 
Figure $1 \mathrm{C}$ offers annual averages for the change in income polarization. It takes Figure 1B and divides all the bars by the number of years in the corresponding period. Therefore, Figure 1C indicates how intensively income polarization has evolved over time. Four observations emerge from this Figure. First, middle-income households have hollowed out at a broadly constant rate of 0.2 percent of total household population per year since 1970. Second, throughout this period, more middle-income households have joined the low- than high-income ranks. For example, during 2000-2016, of the 0.2 percent of total population that have, on an annual average basis, hollowed out of the middle-income ranks, about 0.11 have joined the low-income class, while 0.09 have joined the high-income class. Third, the average annual hollowing out of the middleinto high-income class has increased from an annual average of 0.07 percent of household population before 2000 , to 0.09 percent after 2000 . Fourth and last, the average annual hollowing out of the middle- into low-income class has decreased from an annual average of 0.13 percent of household population before 2000, to 0.11 percent after 2000 .

Throughout this paper, like Alichi et al. (2016), a household's income is defined as the total pretax earnings and transfers to the household head and the second adult in the household (if any). Household income is in real terms in 2005 dollars, using the Consumer Price Index (CPI) as the deflator, and is also divided by the household's size using the equivalence scale from the Organization for Economic Cooperation and Development (OECD). This methodology assigns a value of 1 to the first household member, 0.7 to each additional adult, and 0.5 to each child.

This paper shifts the focus of studying income polarization to the state level. The polarization pattern that has been documented at the national level is also prevalent at the state level but with significant variability. Figure 2 shows that since the mid-1970s, across states, the share of middle-income households (defined here as those earning between 50 and 150 percent of the state-level median income) has fallen. For the median state, the average share of the middleincome households was 561/4 percent of the total household population for 1977-1985 and 501/4 percent for 2006-2016. Figure 2 shows that this 6 percentage points lower share of the middleincome class, was associated with an increase in the share of the high-income households by $23 / 4$ and low-income households by $3 \frac{1}{4}$ percentage points during this period. To give a sense of variation across states, Appendix II shows the evolution of population sizes for different income classes in all the 50 states and the District of Columbia over 1977-2016. In Connecticut, New Hampshire, and West Virginia, the middle-income class has hollowed out the most, but along different dimensions. In Connecticut, 17.8 percent of the total household population, hollowed out of the middle-income class during this period. Of these, 12.2 percentage points joined the high-income class, and the remaining 5.7 percentage point joined to the low-income class. In New Hampshire, 15 percent of the household population hollowed out of the middle-income class, but they have distributed with a more equal balance than Connecticut, with 6.5 percentage point joining the high-income ranks and 8.5 percentage point joining the low-income ranks. West Virginia has also experienced a very high income polarization, but with a very different balance. About 15.5 percent of total West Virginia's household population hollowed out of the middle-income class during 1977-2016. Of these households, only 4.1 percentage points joined the high-income ranks, with the remaining 11.4 percentage points joining the low-income ranks. On the other side of the spectrum, there are a handful of states that have experienced relatively little change in their polarization levels during 1977-2016. In Arkansas, only 1.3 percent of the total household population has hollowed out of the middle-income class during this period. This is the least amongst all states, followed by North Dakota, in which 2.2 percent of the total household population has hollowed out of the middle-income class during this period. 


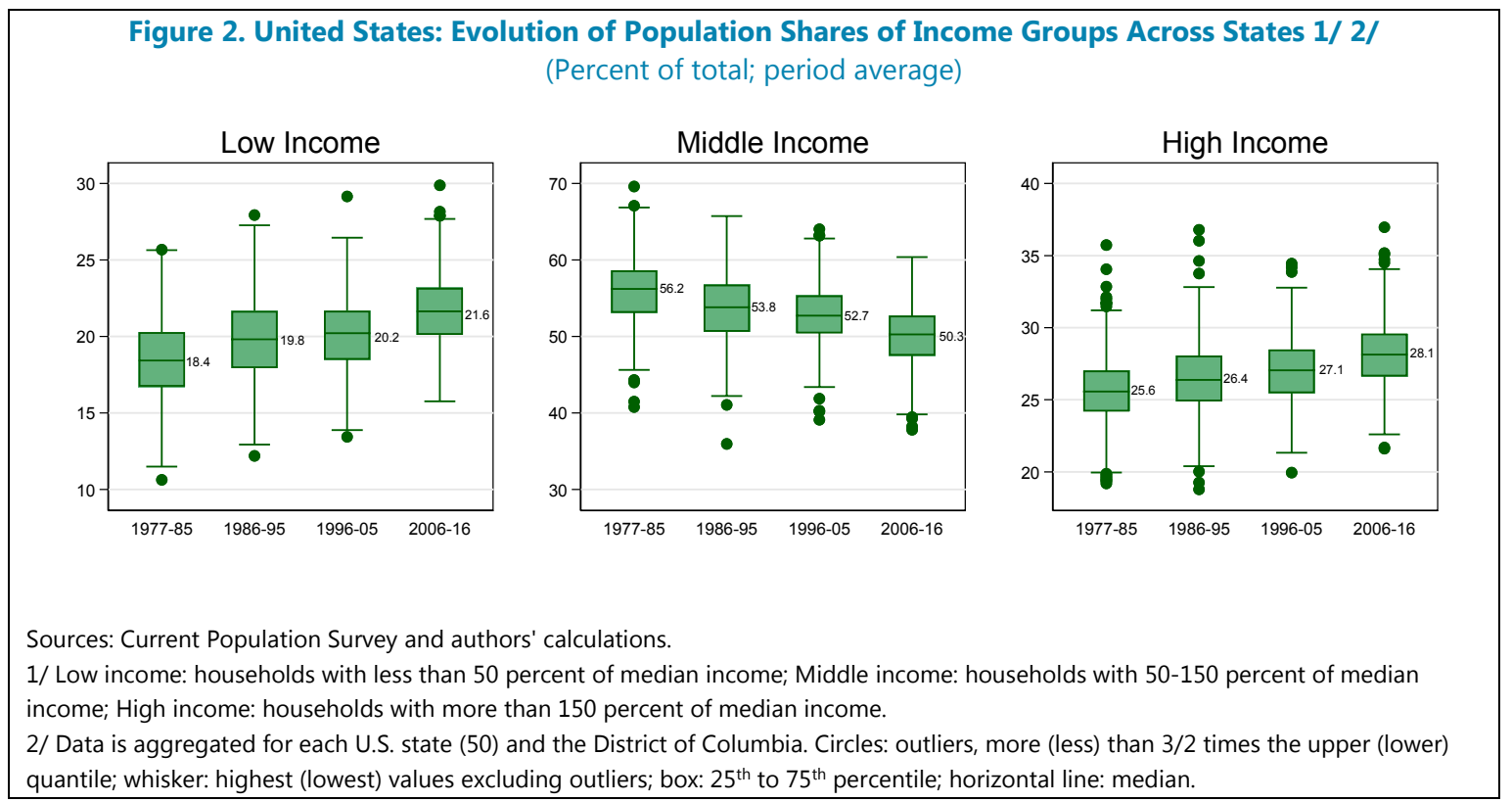

One of the main objectives of this paper is to illustrate why different U.S. states have experienced different degrees of income polarization. Figure 3 presents a very interesting observation from the data: states that have higher median household income (i.e., are richer ${ }^{3}$ ) tend to have larger middle-income class population shares, and smaller low-and high-income class population shares. In other words, the income distribution in richer states is less polarized because they have both relatively fewer low- and high-income households. Politicians generally campaign in favor of the middle class, which is normally perceived as a populist effort to gain votes. However, Figure 3 shows that even ignoring politics, a larger middle class is associated with higher median income and hence more economic prosperity. This is a powerful observation from the data, but one might find it counterintuitive on two fronts:

- How is it possible that with a higher median income, more households do not fall in the lowincome category and hence we do not see the population share of the low-income class to be increasing with the state median income, contrary to the decreasing pattern that Figure 3 shows? The answer lies in two facts: first, the size of different income classes is a relative concept, where sizes of the three income classes always add up to one; and second, as a state's median income increases, on average, more households who were previously in the low-income ranks, disproportionately benefit and hence their incomes increase at a faster pace than the median income.

- On the other hand, one might expect that states with higher median income, such as Massachusetts or Maryland to be magnets for rich households and hence would have a relatively larger share of high-income households, contrary to what Figure 3 shows. However, states with higher median income have a higher bar for qualification as high

\footnotetext{
${ }^{3}$ It is worth emphasizing that a "richer" state is defined in this paper exclusively as one with "higher median income". This is a very important point to bear in mind throughout the paper. For example, using this metric, Maryland and Connecticut, with real median incomes of more than $\$ 35,000$ in 2016 (Figure 3), are considered richer than California and New York, with real median incomes of about $\$ 30,000$. If one alternatively defined "richer" as "having higher total income of a states' residents", California and New York would be assessed much richer than Maryland and Connecticut, given their population sizes.
} 
income (i.e., the high-income qualification cutoff of 150 percent of median in dollar terms increases as the median increases) and hence such states have a smaller high-income household population share.

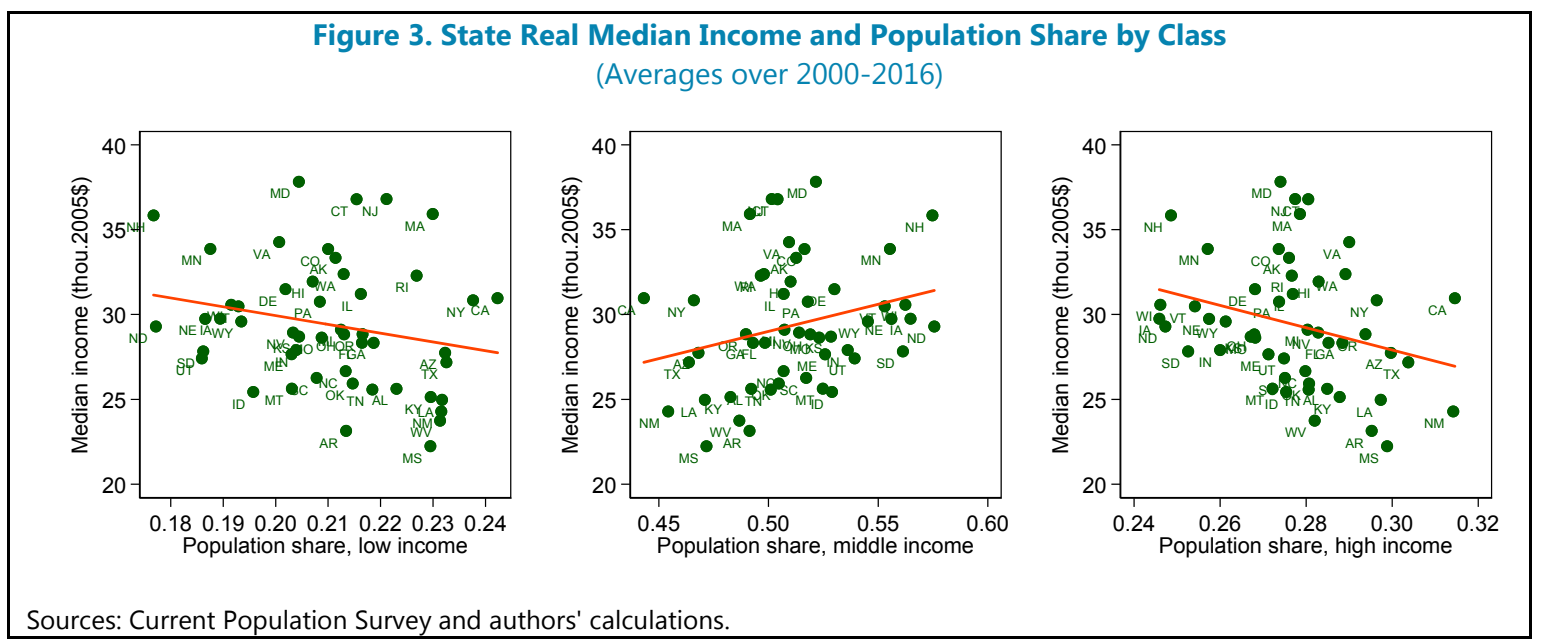

This paper focuses on identifying the proximate causes of income polarization as opposed to the more well-known concept of income inequality. ${ }^{4}$ This is done for two reasons: income polarization captures a specific form of income inequality, namely the "fattening" of the tails of the income distribution that has been documented to have macroeconomic implications, including on domestic demand (Alichi et al., 2016). Second, as shown in this paper, changes in income polarization can be decomposed into downward- and upward- changes in the income distribution which lend themselves to economic and policy analysis. Downward polarization refers to more households joining the lower-income ranks, while upward polarization refers to more households joining the upper-income ranks. In contrast, inequality concepts such as the Gini coefficient, while providing comprehensive statistics of the earnings or income distribution, do not lend themselves to a decomposition of changes that can be attributed to the movements of individual into the tails of the income distribution.

The notion of polarization in this paper is univariate, which is defined only over income. The first such measure was proposed by Wolfson (1994), based on Foster and Wolfson (1992). Alternative polarization measures were offered by Wang and Tsui (2000) and Alesina and Spolaore (1997).

The literature on analyzing the causes of income polarization in the United States is very limited. Autor et. al. (2006) and Goos and Manning (2007) provide some of the first evidence on job polarization while Boehm (2013) explores how job polarization links to wage and, consequently, income polarization. The breakdown of income polarization into two parts, downward and upward polarization is an important new contribution of this paper.

\footnotetext{
${ }^{4}$ See Appendix III for a discussion of the two concepts.
} 
The paper proceeds in two stages. It first presents two indices of polarization, and then unearths potential drivers of polarization using empirical state- and household-level models.

The indices show that polarization has increased steadily since the 1970s in the United States and that both upward and downward polarization have contributed. The econometric analysis at the state level suggests that technology, measured by job routinization, and international trade, measured by job offshoring, can explain more than half of the rise in income polarization, with broadly equal contributions. Household characteristics, including education, age, race, and gender have also been important drivers but on net have had a countervailing effect on income polarization. This is mainly thanks to the rising education level of households, which has led to better incomes.

Section II develops two indices to represent the level of income polarization. Section III offers the estimation results for the effects of different factors on income polarization at the state level. This section also exploits the household-level micro data to examine the determinants of income polarization. Section IV concludes.

\section{Measuring Income Polarization}

While both polarization and the more-wellknown concept of inequality help assess the income distribution, they have one notable difference. Inequality indices, such as the Gini coefficient, focus on the distribution of incomes given the distribution of the households. Polarization indices also focus on the distribution of incomes, but they give additional prominence to the median of the distribution, which serves as a benchmark to break the household population into different groups. For example, Wolfson (1994) offers an index of income polarization based on the mass of the population that finds itself above or

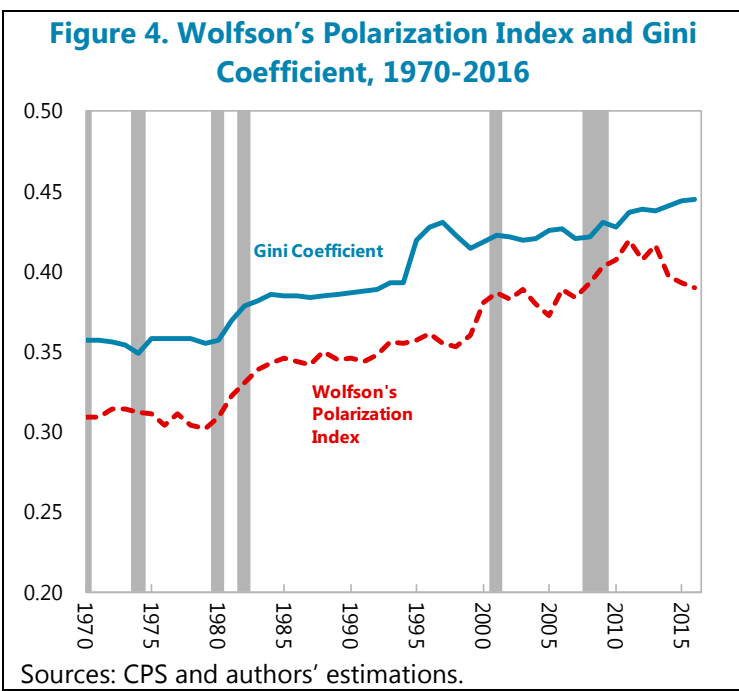
below the median income, weighted by a variable related to the distance of that household's income from the median. Appendix III discusses in detail how this index is constructed. Figure 4 shows a steady trend increase in both the Gini coefficient and Wolfson's measure of income polarization at the U.S. national level since $1970 .^{5}$

A drawback of Wolfson's index is that it does not allow us to make any statements about the middle-income class because the separating concept in this index is only the median income, which divides the household population into only two groups (those below and above the median). Furthermore, Wolfson's index is an overall index that cannot be easily broken into

\footnotetext{
${ }^{5}$ Differences of the series in this chart and its equivalent in Alichi el al. (2016) are due to two additional years of data (2015-16) and incorporation of CPS's household population weights in the calculation of the median in the current chart. Alichi et al. (2016) did not incorporate the population weights, but the current paper does so for increased accuracy.
} 
downward and upward shifts of households over the income distribution. ${ }^{6}$ We develop two additional indices of income polarization that tackle these deficiencies of Wolfson's index and allow us to study the middle-income class directly. These indices draw to a different degree on the relative position of household incomes in the overall income distribution, and one of these indices, in addition, directly draws on income dispersions.

It should be clarified at the outset that the notion of income polarization studied throughout this paper is a "relative" concept where income is defined relative to that of the median household in each year. Alichi et al. (2016) and Pew (2015) use this relative definition. Others have preferred an absolute concept of income polarization. For example, Rose (2016) defines the low-, middle-, and high-income classes relative to the real median income for the last year of observations.

\section{A. Population-share Index}

This index gauges income polarization by a simple measure of the relative size of the middleincome group (a more polarized economy has a relatively smaller middle-income class). It is defined as the share of the household population that is not in the middle-income class in each state $s$ and year $t$ :

$$
\operatorname{sharehol}_{t}^{s}=1-\text { popshare }_{t}^{m, s}
$$

Where, popshare $t_{t}^{m, s}$ is the share of the middle-income households in the household population in state $s$ and year $t$. These are the households whose real size-adjusted incomes fall between 50 to 150 percent of the median income.

This index can be divided into separate indices for downward and upward polarization. These would simply be popshare $t_{t}^{l, s}$ and popshare $t_{t}^{h, s}$, which are respectively the shares of low- and high-income households in the population. Low-income households are those whose real sizeadjusted incomes are less than 50 percent of the median, while high-income households are those whose real size-adjusted incomes are more than 150 percent of the median.

Figure 5 shows the evolution of the downward and upward, and overall population-share indices. While the top panel highlights these indices only for seven years $(1970,1977,1984,1992,2000$, 2008, and 2016), the middle and bottom panels report it for the full period. The message of Figure 5 is straightforward: the overall, downward, and upward population-share indices have all seen a notable increase in their trends since the 1970s, indicating the rising income polarization at the national level in both downward and upward directions. In terms of magnitudes, downward income polarization has been relatively more severe than upward. The downward population-share index has grown by more than 30 percent, while the upward population-share index has grown about 15 percent during 1970-2016. The overall population-share index has grown about 30 percent. In other words, using this measure, the U.S. income distribution has become more polarized by about 30 percent during less than half a century (1970-2016). This result by itself should be very alarming for the policymakers, especially given the results of Alichi et al. (2016) and the literature on inequality, which has established that there are notable negative macroeconomic consequences when the middle-income class shrinks and the nation's income distribution becomes polarized.

\footnotetext{
${ }^{6}$ In addition, we are not aware of an economic interpretation of Wolfson's index.
} 


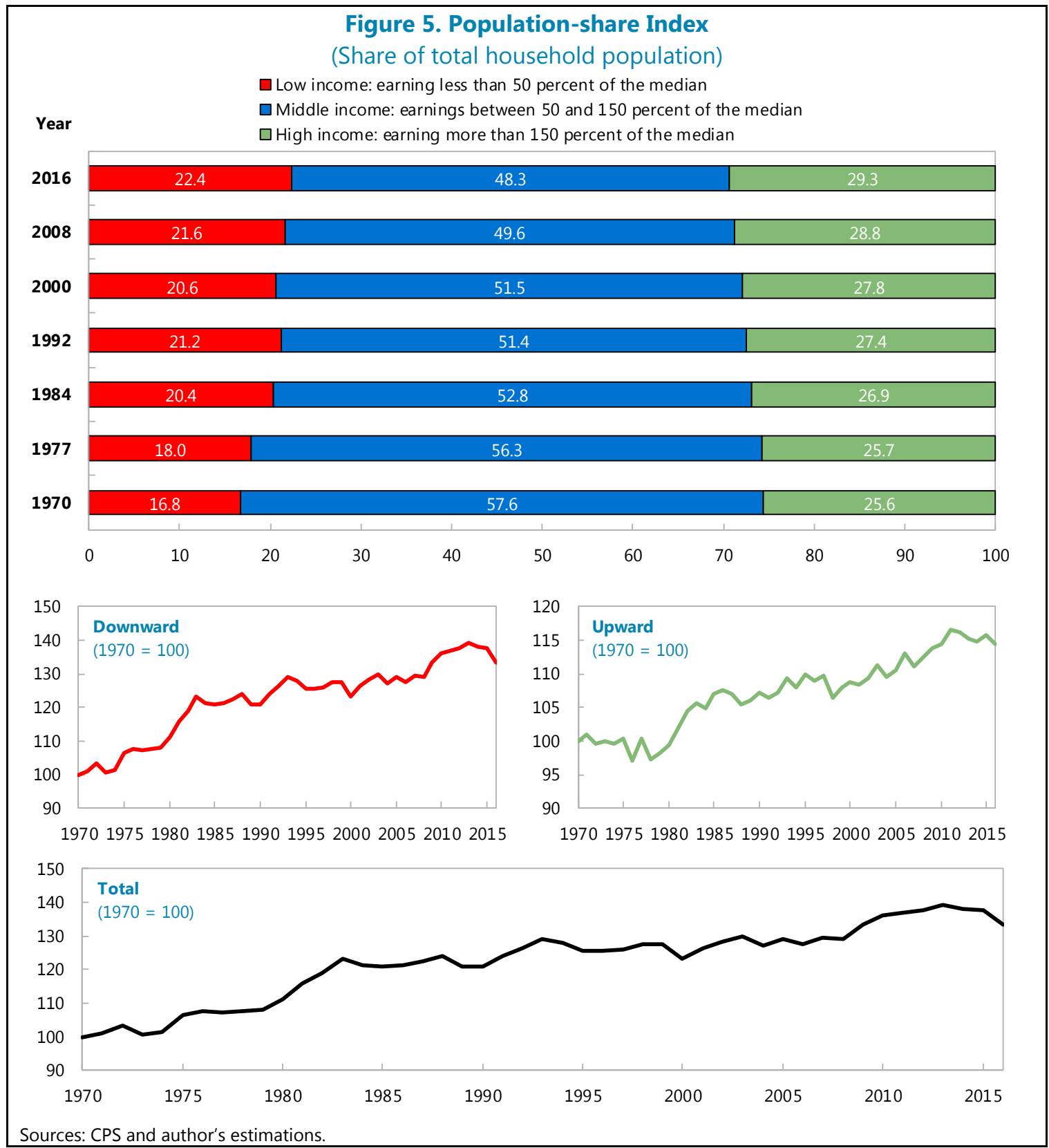

Having seen the rise of income polarization, as measured by the population-share index, one would wonder which jobs and employees have been most affected. Figure 6 breaks down Figure 1B by employment and employee characteristics. Similar to Figure 1B, in Figure 6, all the bars represent period changes in percent of "total household population", rather than the population of a certain income class. The top left chart of Figure 6 shows that during 1970-2016, the share of middle-income class jobs in manufacturing and construction fell and the majority of these jobs were "replaced" with both low- and high-income jobs in services. During this period, about 18 percent of total households have lost their manufacturing sector jobs, of which 12 percentage points have been middle income. About a third of these households got high-income jobs in the

\footnotetext{
${ }^{7}$ Replaced is used loosely in this context since this is the net effect over time of new entrants to the labor market, exits from employment, and changes in the sectoral employment of those that remained in the labor force.
} 
services sector, with most of the rest getting services jobs in the low- and middle-income ranks. The top right chart of Figure 6 shows that many middle-class salary jobs, especially in the private sector, have been replaced by either salary jobs in the low- and high-income ranks or self-employed jobs.

Regarding the household characteristics, the middle left chart of Figure 6 shows the aging of the workers, especially since the turn of the current century, as younger employees have been replaced by older ones. The middle right chart of Figure 6 shows that throughout 1970-2016, low-education middle-class jobs were replaced with higher-education jobs in all income classes. Therefore, aging and education, were countervailing forces to the polarization process. Finally, the bottom charts of Figure 6 show that male employment has declined, mostly concentrated in middle-income jobs, while female employment has risen across the entire income distribution. Additionally, middle-income jobs of the U.S.-born households have been replaced by jobs for foreign-born residents at both ends of the income distribution. 


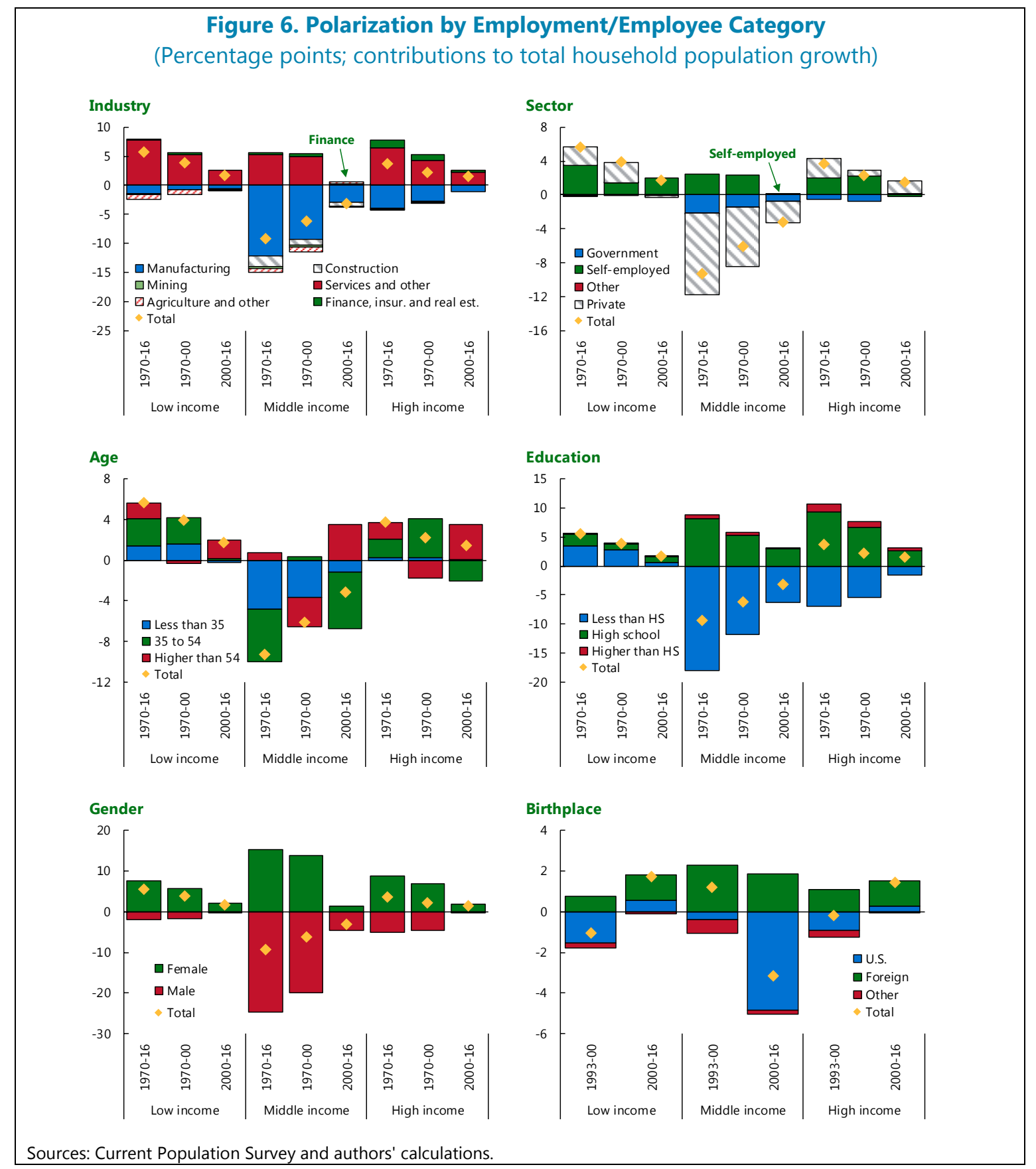

\section{B. Income Hollowing-out Index}

While the population-share index captures income polarization through focusing on the population distribution of households, conditional on the median income, it does not fully capture how strongly households' incomes are polarized. For example, if a household leaves the middle- and joins the low-income ranks, the population-share index changes equally whether the household joins the bottom or top of the low-income range. Ideally, a polarization index should 
differentiate between the two. ${ }^{8}$ We address these issues through our second index of income polarization, which we call the income hollowing-out index.

The income hollowing-out index is a novel index based on average deviations of incomes of the middle-income class households from the median. We explain this index using the second right chart of Figure 7 from the top, which includes two Lorenz curves: the darker black solid curve is the actual Lorentz curve of the U.S. households, using the CPS data for $2016 .{ }^{9}$ The lighter dotted black line is the 45-degree line, which is the Lorenz curve for a hypothetical benchmark case of a household income distribution with zero polarity (and zero inequality). The blue box in the chart is the area under the Lorenz curve for the middle-income class of the benchmark population, who are households with incomes between 25 to 75 percent of the total incomeequivalents of 50 to 150 percent of the median income for the benchmark case. The yellow area, is the equivalent of the blue box, but for the actual middle-income class population who earn between 50 to 150 percent of the household population's median income in 2016. The income hollowing-out index is then defined as the blue minus yellow areas. Intuitively, this index captures how far the middle class's income is from a hypothetical benchmark income distribution with zero polarity. The larger the hollowing-out index, the farther the income distribution is from the benchmark and hence the more polarized the income distribution is.

Like the population-share index, the hollowing-out index can also be broken into the downward and upward components. To break down this index into the downward and upward components, we simply need to break the middle-income class into two parts: those whose incomes are below the median and those whose incomes are above..$^{10}$ The downward hollowing-out index is then the same concept as the overall hollowing-out index, but defined only over those middle-income households whose incomes are below the median. This is the blue minus yellow area that falls to the left of the vertical line at 0.5 in Figure 7. Likewise, the upward polarization index is the same concept as the overall hollowing-out index, but defined only over those middle-income households whose incomes are above the median. This is the blue minus yellow area that falls to the right of the vertical line at 0.5 in Figure 7.

\footnotetext{
${ }^{8}$ It should be noted that Wolfson's index does scale by how far a household's income is from the median income, but we do not find it a very attractive measure for polarization for the reasons explained in the beginning of Section II.

${ }^{9}$ All the four charts at the top of Figure 7 have been produced in the same manner. We explain them based on the most recent year, which is 2016 , and is the second right chart from the top,

${ }^{10}$ We could have equivalently defined the downward and upward hollowing-out indices based on the areas to the left and right of the blue and yellow areas. This alternative way of defining would have made the reader able to draw an easier parallel between the hollowing-out and population-share indices. However, we find it very challenging to present the alternative definition graphically and prefer the current definition.
} 


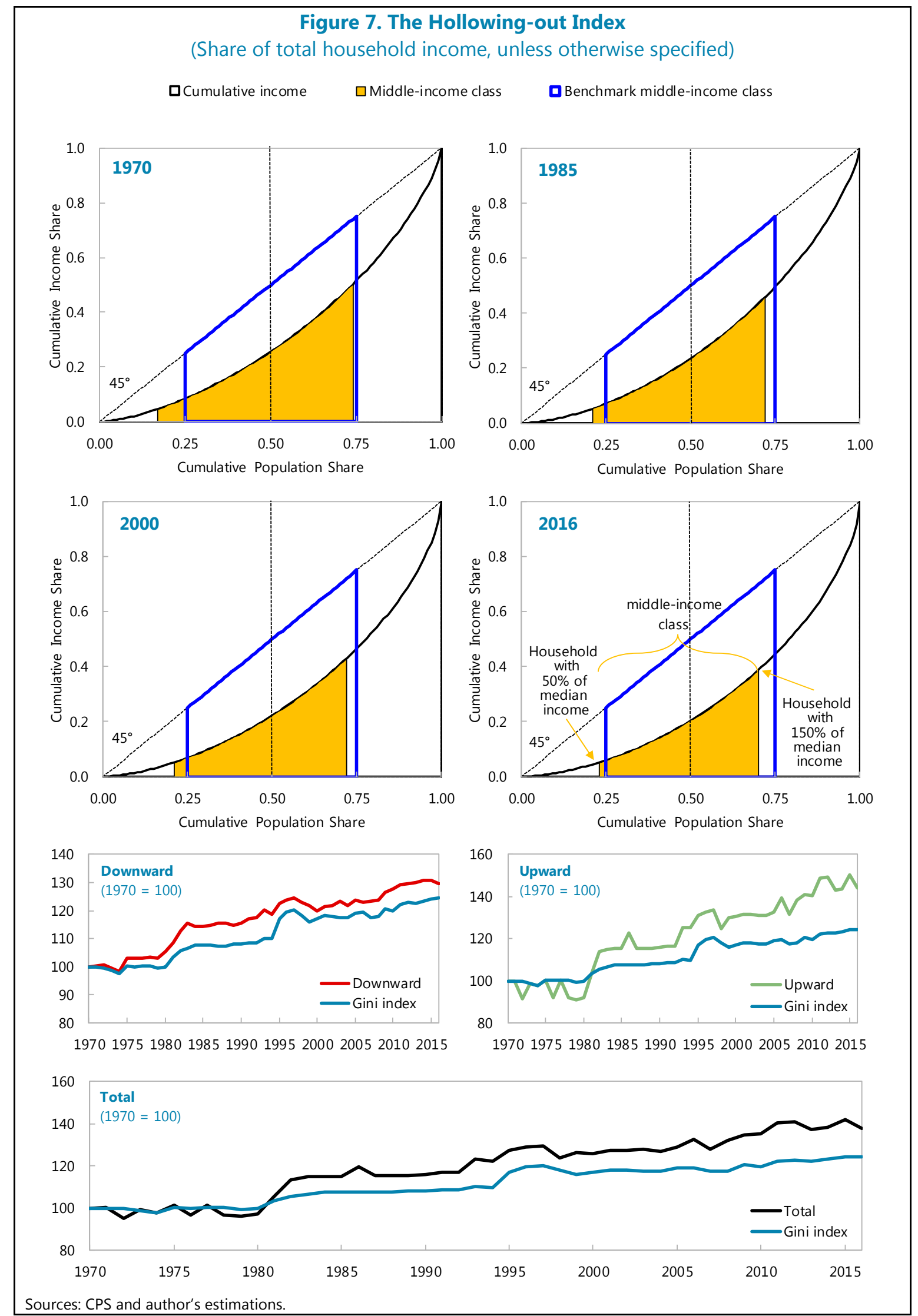

CInternational Monetary Fund. Not for Redistribution 
Figure 7 also shows the evolution of the hollowing-out indices over 1970-2016. The four top charts show that going from 1970 to 2016, the yellow area has shrunk both from the left and right, reflecting a shrinking income share for the middle-income class, which has led to an increase in both the upward and downward income hollowing-out indices. ${ }^{11}$ This is confirmed in the bottom three charts of Figure 7, which show that the overall, downward, and upward hollowing-out indices have grown about 30-40 percent during 1970-2016. This increased polarization that is shown using the hollowing-out index, very well corroborates with the trends shown in the previous subsection using the populations-share index (Figure 5).

One may find it striking that all the hollowing-out indices experienced a sharp upward level shift in the early 1980s (Figure 7). We verify in Figure 8 that this was due to sharp shifts in the Lorenz curve. The left panel of Figure 8 plots the differences of the Lorenz curves for the years after 1980 with the Lorenz curve of 1980. It shows that there was a sharp downward shift in the Lorenz curve during 1981-82, which was not reversed thereafter. Conceptually, we find it hard to justify such a sharp permanent jump in the Lorenz curve, given that annual changes in the income distribution should be a slow-moving process. We suspect the sharp shifts in the Lorenz curve during 1981-82 have a technical nature, perhaps due to changes in the CPS top coding starting those years. Other episodes of sharp changes in the hollowing-out indices are temporary and could be either due to the economic cycle or a technical sampling issue, like what we described for the 1980s. For example, Figure 7 shows a temporary sharp rise in the upward hollowing-out index in the mid-1990s. The right-panel of Figure 8 plots the differences of the Lorenz curves for the years after 1994 with the Lorenz curve of 1994. There was a large downward shift in the Lorenz curve in 1996-97, which was partially reversed in the following years.

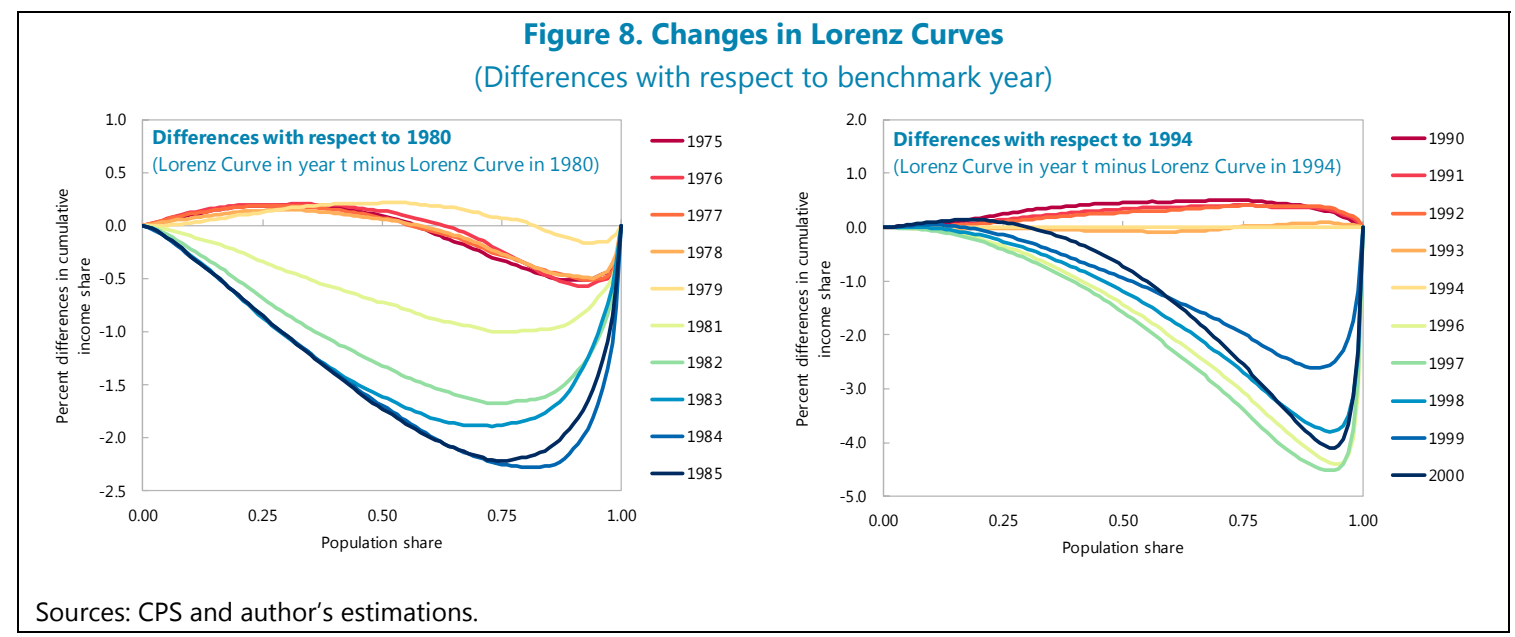

${ }^{11}$ As a reminder, the area of the benchmark blue box is always constant. 
Formal definition of the hollowing-out index

Having explained the income hollowing-out index graphically, conceptually, and numerically, we can now formally define the index for completeness. The hollowing-out index is defined as follows:

$$
\text { Hollowng-out } t_{t}^{s}=4(\underbrace{\int_{i=0.25}^{0.75} i \cdot d i}_{\text {blue area, Fig.7 }}-\underbrace{\int_{i=L}^{1-H} y_{t}^{i, s} \cdot d i}_{\text {yellow area, Fig.7 }})=1-4 \int_{i=L}^{1-H} y_{t}^{i, s} \cdot d i
$$

Where, $L$ and $H$ are the populations of households whose real size-adjusted incomes are less than 50 and more than 150 percent of the median, respectively; $y_{t}^{i, s}$ is value of the Lorenz curve at household $i$ in state $s$ at year $t$. The definition above shows how the index is related to Figure 7 . As discussed before, the index is defined based on the area surrounded by the blue box in Figure 7 minus the yellow area. The index is multiplied by 4 to normalize to the $0-1$ range.

The downward and upward hollowing-out indices are defined consistently. The downward income hollowing-out index in state $s$ at year $t$ is defined as follows:

$$
\text { Hollowng-out } t_{t}^{l, s}=4(\underbrace{\int_{i=0.25}^{0.50} i \cdot d i}_{\begin{array}{c}
\text { blue area, Fig.7 } \\
\text { left of median }
\end{array}}-\underbrace{\int_{i=L}^{0.50} y_{t}^{i, s} \cdot d i}_{\begin{array}{c}
\text { yellow area, Fig.7 } \\
\text { left of medians }
\end{array}})=0.375-4 \int_{i=L}^{0.50} y_{t}^{i, s} \cdot d i
$$

In a similar way, we define the upward income hollowing-out index, based on the definitions of the high-income households as follows:

$$
\text { Hollowng-out } t_{t}^{h, s}=4(\underbrace{\int_{i=0.50}^{0.75} i \cdot d i}_{\substack{\text { blue area, Fig.7.7 } \\ \text { right of median }}}-\underbrace{\int_{i=0.50}^{1-H} y_{t}^{i, s} \cdot d i}_{\substack{\text { yellow area, Fig., } \\ \text { right of median }}})=0.625-4 \int_{i=0.50}^{1-H} y_{t}^{i, s} \cdot d i
$$

While Figure 7 presented the hollowing-out index at the U.S. national level, Figure 9 does so at the state level, using the definitions above. Figure 9A shows a snapshot of the states' downward and upward hollowing-out indices in 2016. The top panel shows the downward polarization levels. It divides the U.S. states and the District of Columbia - a total of 51-into three buckets of 17 states. The states marked as red are the 17 states with the highest levels of downward polarization (i.e., with the highest levels of the downward hollowing-out index) in 2016. The 17 states with the lowest levels of downward polarization are in ivory color. The remaining 17 states whose downward polarization comes in the middle are in orange color. The bottom panel of Figure 9A shows the upward polarization levels. It also divides the U.S. states and the District of Columbia into three equally-sized buckets of 17 states. The dark green bucket includes the 17 states with the highest levels of upward polarization. The 17 states with the lowest levels of downward polarization are in yellow color. The remaining 17 states whose downward polarization comes in the middle are in bright green color. While it is difficult to fully generalize, it appears that the eastern and some mid-western states have had the highest levels of (downward and upward) income polarization in 2016. The coastal states in the west and southern 
states have had moderate levels of income polarization and the remaining states in the mid-west, center and north have had the lowest levels of income polarization in 2016.

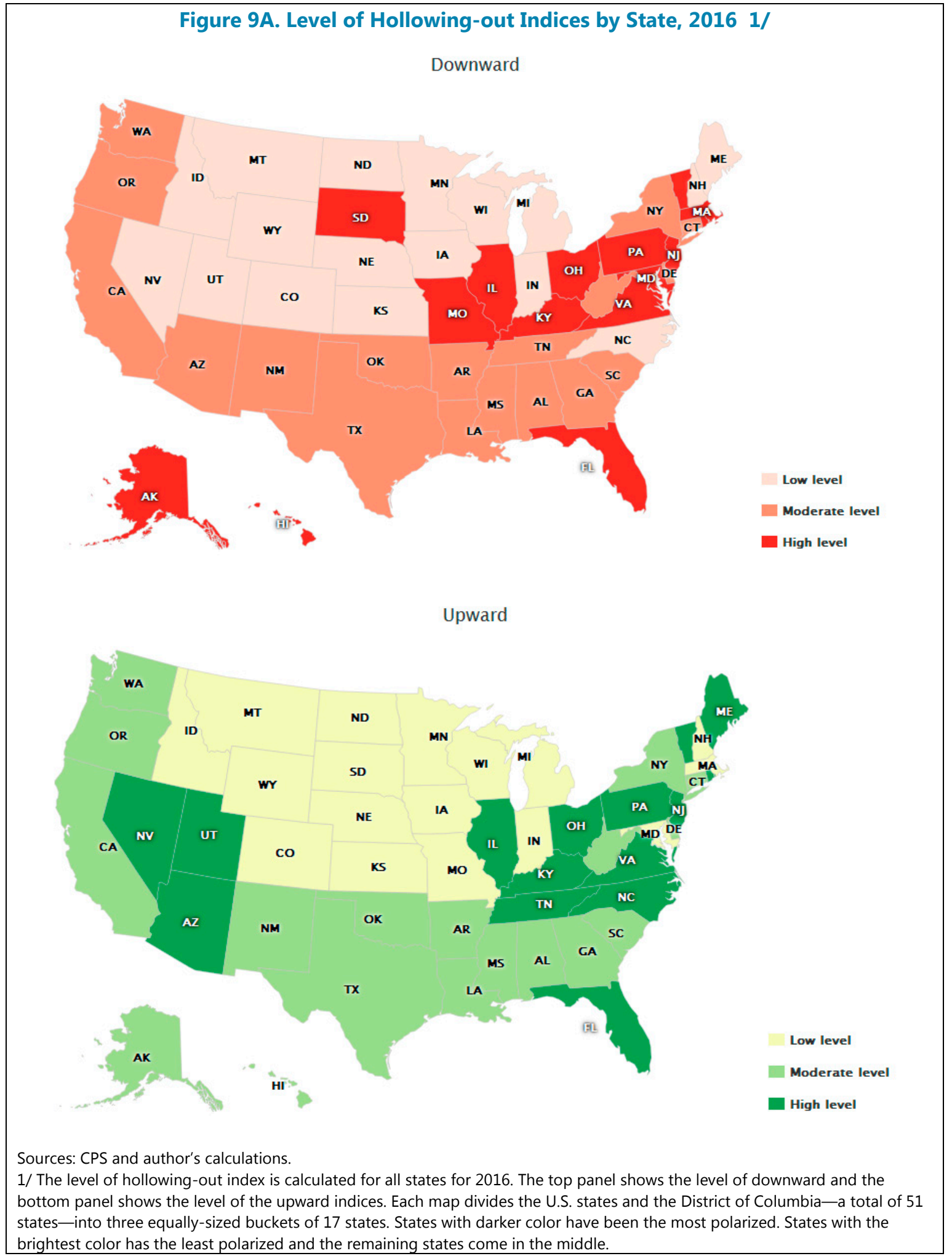

While Figure 9A provided a snapshot of the hollowing-out indices for the U.S. states in 2016, Figure 9B provides the average and ranges of these indices over the states during 1977-2016. These indices are normalized by their average value in 1977 to provide an easier picture of how 
they have evolved over time. Like the national trend that was shown in Figure 7, one can see in Figure 9B that the average downward and upward hollowing-out indices for states also have risen throughout the sample. However, the ranges of deviations across states (shown by the dotted lines in Figure 9B) indicate large heterogeneities in the evolution of hollowing-out across different states.

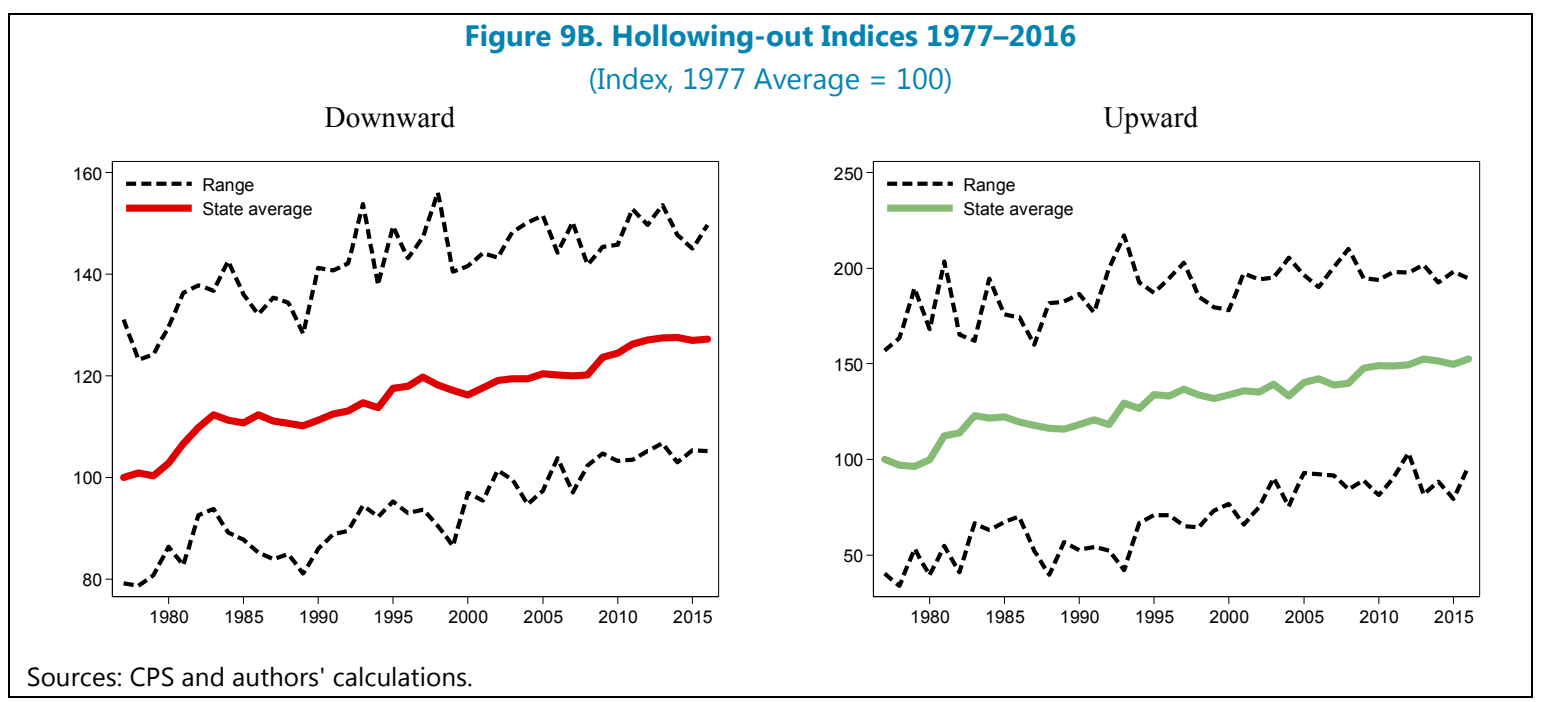

\section{Comparison of the Polarization Indices}

In this subsection, we compare the two indices that we developed in the previous subsection, namely, the population-share and hollowing-out indices. We first provide a definitional comparison and then compare the trends of the two indices over the sample period.

The hollowing-out index is a measure of income polarization that captures the income sharei.e., income times population - of the middle-income households in total, while the populationshare index only captures their population share. For a graphical interpretation, let's briefly return to Figure 7 and focus on the second right chart from the top (2016). As discussed before, the hollowing-out index is calculated by subtracting the yellow area from the blue area-with the latter area being a constant. The yellow area is related to the population-share index in the sense that its horizontal-axis coordinates are exactly those of the population-share index: the lower cut-off for the yellow area on the horizontal axis is the household with 50 percent of the median income, while the higher cut-off for the yellow area on the horizontal axis is the household with 150 percent of the median income. 
Figure 10 shows the trends of the population-share and hollowing-out indices (downward and upward) from 1977. These are average indices over all the U.S. states and the District of Columbia.

The top panel shows that both indices have had broadly similar downward polarization trends. This is due to low variability among incomes of the low-income households. Both indices show a sharp rise in the early-1980s (which as explained before could be partly due to changes in the CPS top coding) and have generally increased thereafter too. Both indices have also observed another sharp rise after the global financial crisis, followed by some correction thereafter.

Notwithstanding the similarities, the downward hollowing-out index has generally been less volatile than the downward population-share index. This indicates that at the bottom of the distribution while population has increased and income growth has been relatively weak, the former has had a more pronounced effect on the downward hollowing-out index.

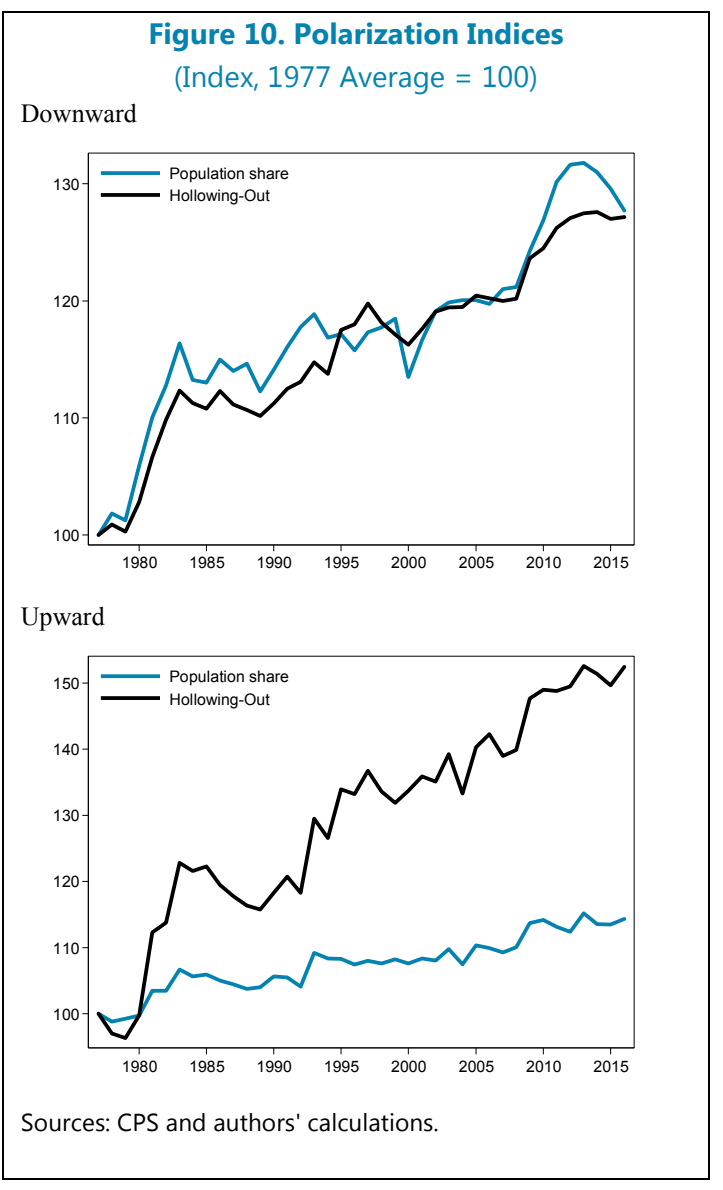

The bottom panel of Figure 10 compares the upward indices. Contrary to the case of the downward indices, the paths of the upward indices are very different from each other. This is because the incomes of the high-income households have grown much faster than their population shares in the past decades. This has resulted in a sharper rise in the hollowing-out index, which is income-weighted, compared to the population-share index, which is not income weighted. Notwithstanding, both upward indices have also seen a sharp rise in the early-1980s and have generally risen thereafter too.

\section{Channels OF INCOME POLARIZATION}

Having developed two indices of income polarization in the previous section, we now turn to another main objective of the paper, which is to examine the channels of increased income polarization in the United States. Appendix I explains the data in detail. ${ }^{12}$

Conceptually, income polarization should depend on two sets of factors: the household's personal characteristics, and the household's job characteristics:

Personal characteristics: we consider age, education, race, and gender as potential determinants of household incomes. Figure 11 provides 4 scatterplots relating these variables to the median income in different states, which could help inform our priors ahead of doing a regression

\footnotetext{
${ }^{12}$ Our study at the state-level starts in 1977, about a decade later than the national level. This is because of availability issues of data for some states prior to 1977 and some top coding changes as well, as described in Appendix I.
} 
analysis. First, Figure 11 shows that states with a higher average age of household heads, also have higher median incomes. This is because higher age is an indicator of more experience, which is positively associated with higher income, ceteris paribus. Second, Figure 11 shows that, on average, states that have more educated household heads also have higher median incomes. This is consistent with the well-documented fact that more education raises incomes. Third, Figure 11 shows that the states' median incomes do not vary much by their share of non-white population..$^{13} \mathrm{We}$ are not surprised by this result because it is not conditional on other factors. On one hand, there are quite a few states, like New Hampshire and Massachusetts, with predominantly white populations and high median incomes. On the other hand, there are quite a few states like West Virginia and Kentucky, which are also predominantly white, but with low median incomes. However, when one controls for other factors, the racial composition of workers could potentially become important in explaining a state's median income. For example, when one controls for education, it is plausible to expect that states that have a whiter population also have higher median incomes. We shall return to this subject in the next subsections when we do our regression analysis. Fourth and last, Figure 11 also shows that states with relatively more single-female-headed households with children have lower median incomes. This is true because such households on average have lower incomes and higher poverty rates. If one takes this one step further and plots the scatter plot of the share of all female-headed households and state's median income, the picture is qualitatively similar (not shown).

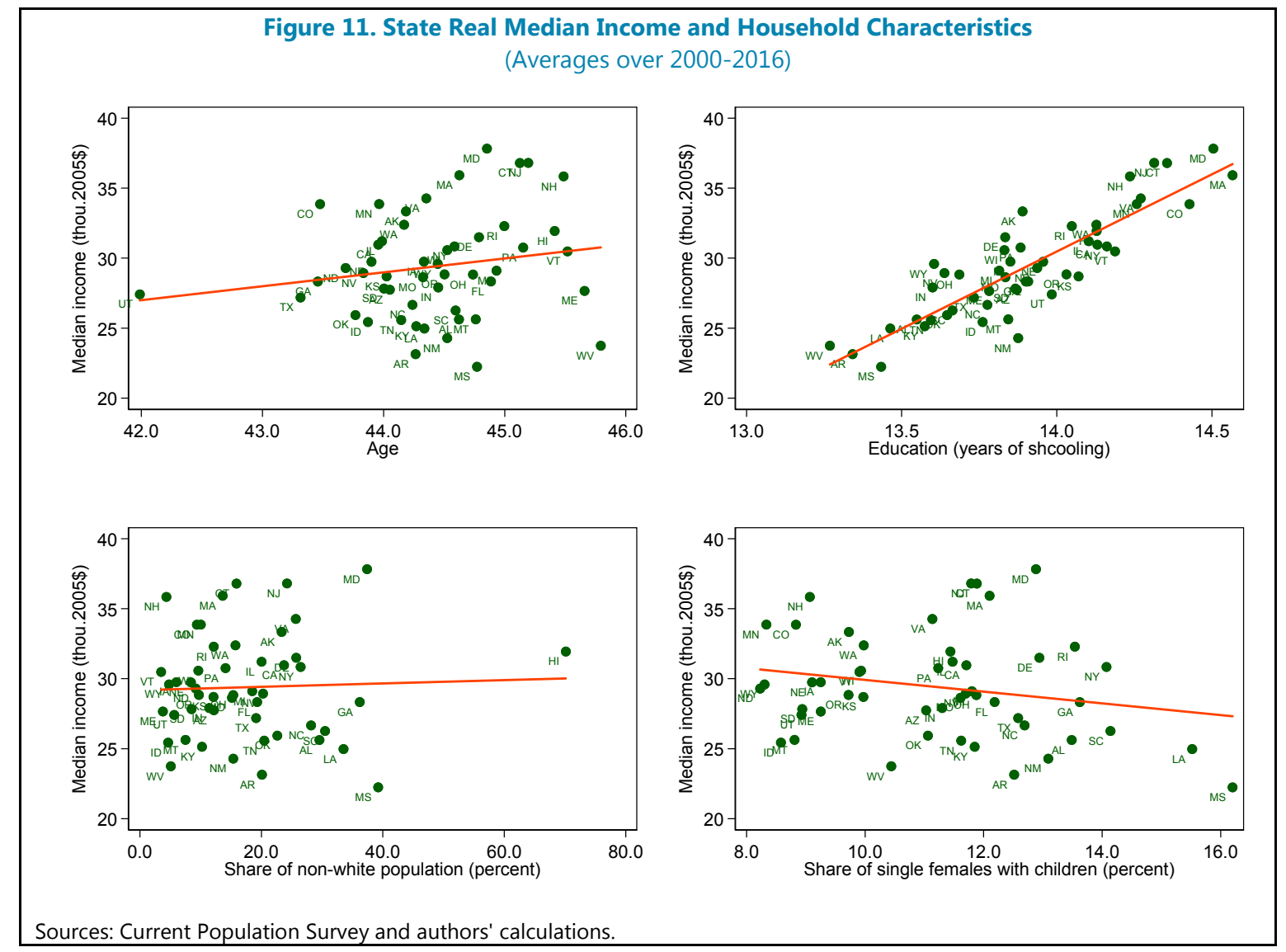

${ }^{13}$ Ideally, we would have used more detailed variables for race, separating whites, African Americans, Latino's, etc., but data for most of these variables are not available for most of our sample. 
Combining the correlations from Figures 3 and 11 enables us to make priors on what we should expect on the link between income polarization and a state's average personal characteristics. As the education level of a state increases, so does its median income (Figure 11). As the median income of a state increases, both the downward and upward polarization levels in the state decrease because the share of the low- and high-income households decreases (Figure 3). Combining these, one can expect that the average education level in a state would have a negative correlation with both downward and upward polarization in that state. In a similar fashion one can conclude that states with higher average age and lower share of single females with children, also have lower downward and upward polarization. Finally, there is no apparent link between the share of non-whites and polarization in a state. It is important to note again that these correlations are unconditional and only helpful for us to have some priors on what we should expect from our regressions in the next section. In the regressions, we will have conditional relationships of these variables with polarization, which would not be necessarily like the unconditional ones in the section.

Job characteristics: We choose our variables on job characteristics in a broad way, focusing on technology and international trade, which could affect income polarization either through lowering the compensation for a job or eliminating it altogether. The variables are the share of manufacturing jobs in total in each state, as well as the states' offshoring and routinization levels. The latter two variables are constructed based on the offshorability and routinizability scores that are explained in Appendix I. Specifically, the offshoring level is the average of inverse offshorability scores of all jobs in each state and year multiplied by 100 . Similarly, the routinization score is the average of inverse routinizability scores of all jobs in each state and year multiplied by 100 . The more the jobs in a state have already become offshored and routinized, the less room for them to become further offshored and routinized. Therefore, the routinization and offshoring levels have an inverse relationship with their counterparts of offshorability and routinizability scores. While offshorability and routinizability scores measure, on average, how "potentially" offshorable and routinizable a state's jobs at each year are, the offshoring and routinization levels show that over the previous years, how severely jobs in a state have "already" become offshored and routinized. Figure 12 plots the distributions of these four variables. One can see that, e.g., the median of offshorability score is about 30 , whereas the median of offshoring level is about 3 , which is about the inverse of 30 times 100. A similar relationship holds between the routinizability score and routinization level.

We next focus attention to Figure 13, which provides scatterplots of median income versus the share of manufacturing jobs, and the offshoring and routinization levels across the U.S. states (averages over 2000-2016). The left chart of Figure 13 shows that states with a higher share of manufacturing jobs, also have a higher median income. This is because manufacturing jobs are generally better paid than other jobs (controlling for other factors). The middle and right charts of Figure 13 show that there is a positive relationship between a state's median income and its level of offshoring and routinization. In other words, in the states that have experienced relatively more offshoring and routinization in the previous years, the remaining jobs which are relatively less offshorable and routinizable, are better paid jobs. 


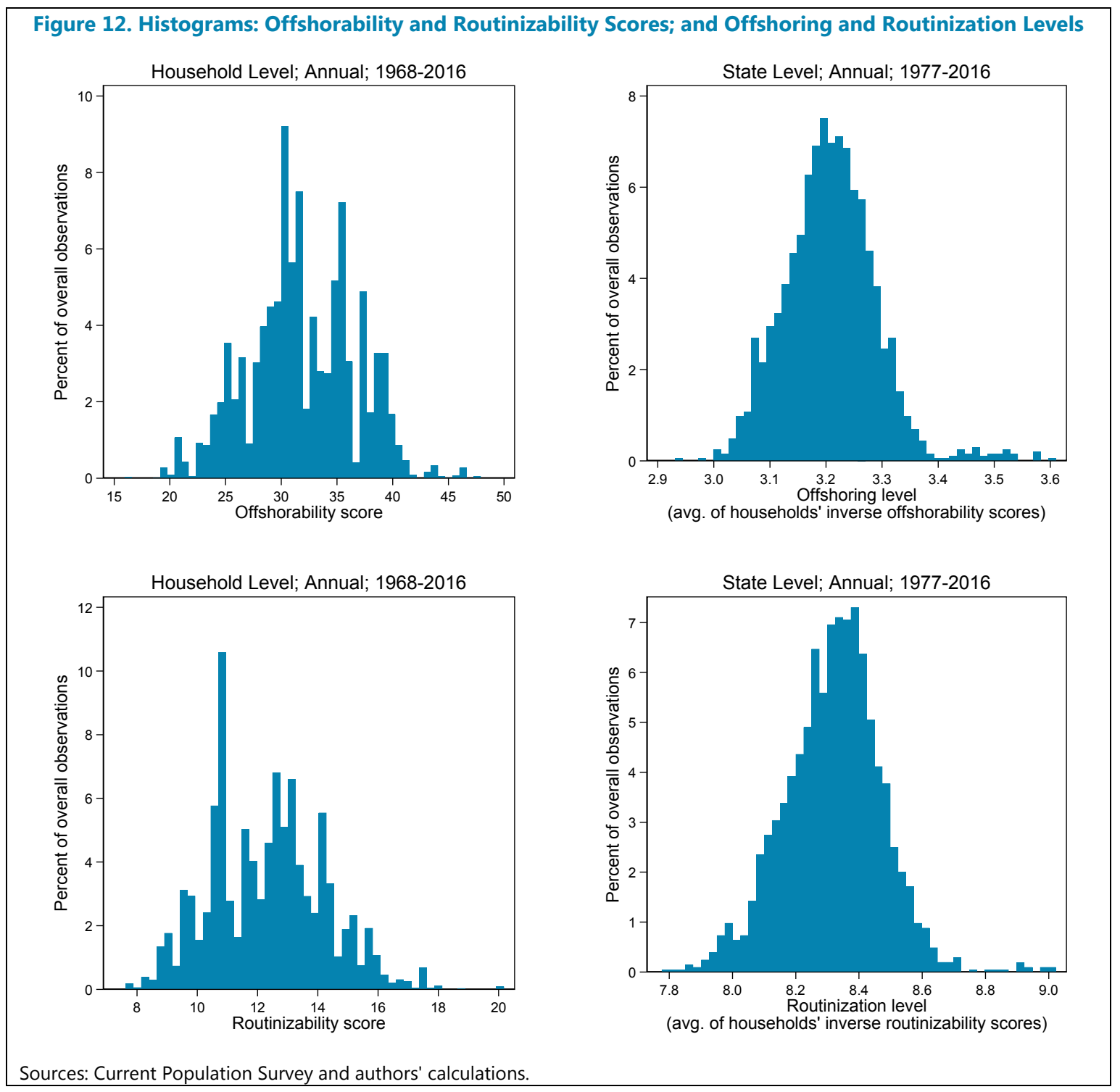

Like household characteristics, we can combine the correlation of job characteristics with the states' median incomes (Figure 13) and the correlation of states' median incomes and polarization levels (Figure 3) to form priors on the relationships of states' polarization levels and job characteristics. These suggest that a state with higher income polarization also has a lower share of workers in the manufacturing sector and higher offshoring and routinization levels. We should emphasize once again that these correlations are unconditional to form some priors on our regression results and need not be like the conditional correlations that we get from our regressions in the following subsections. 


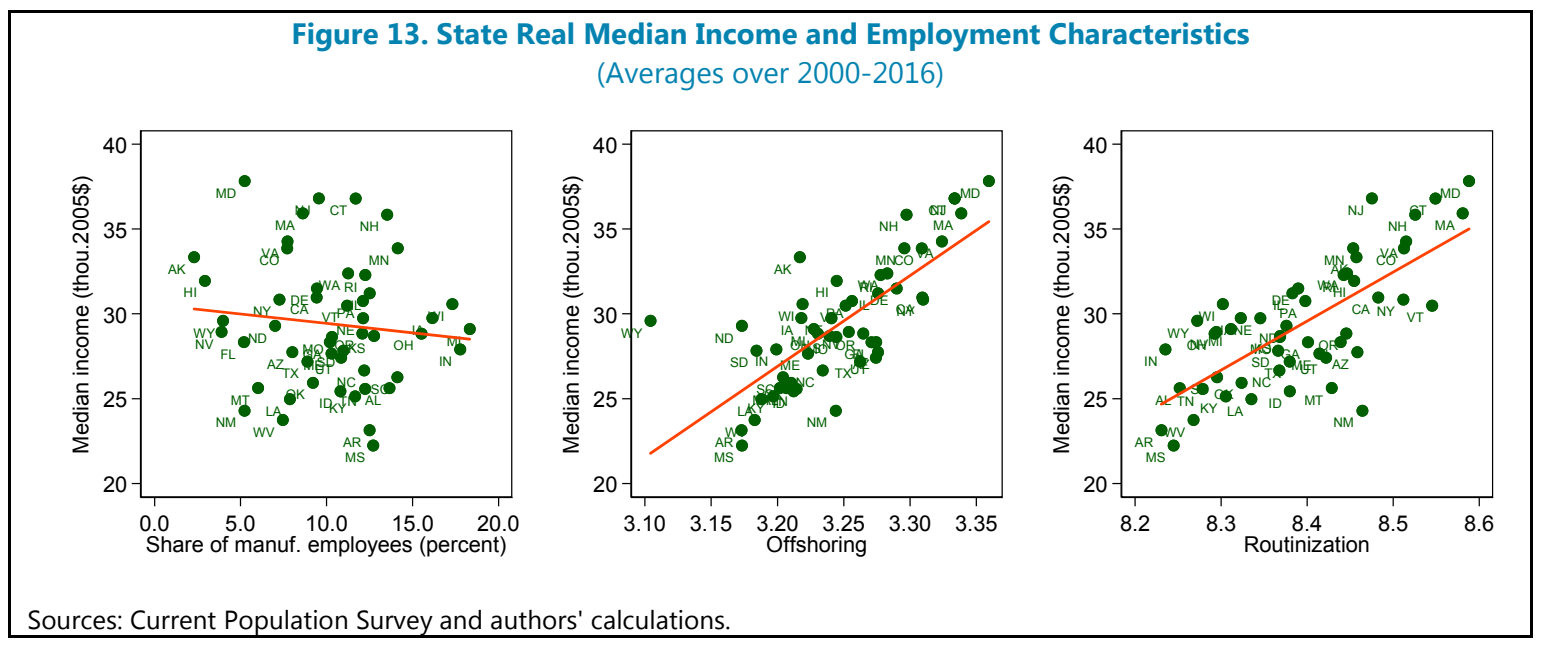

Having developed some priors on the potential channels of income polarization, we continue our empirical analysis in the rest of this section as follows. Regressions at the state and household levels are presented in subsections B and C, respectively. The state-level regressions are done with the hollowing-out and the population-share indices as the dependent variables and averages for the household and job characteristics at the state level as independent variables. The household-level regressions, on the other hand, have households' real size-adjusted incomes as a share of the median income, as the dependent variable, and households' personal and job characteristics on the right-hand side. The household-level regressions are provided to show that the determinants of income polarization are robust to the definition of the polarization index.

\section{A. State-Level Regressions}

Regressions are done on the panel of the 50 U.S. states plus the District of Columbia. The model used is as follows:

$$
\operatorname{Index}_{s, t}=\alpha+\delta \operatorname{Index}_{s, t-1}+X_{s, t}^{\prime} \beta+\mu_{s}+\lambda_{t}+\varepsilon_{s, t}
$$

The dependent variables (Index) are the hollowing-out and the population-share indices; subscript $s$ denotes the state and $t$ is the year. $X_{s, t}^{\prime}$ is a vector of household and job characteristics. The $\mu_{s}$ term is a state specific effect, while $\lambda_{t}$ is a time fixed-effect estimated using time dummies.

The coefficients are estimated with Blundell and Bond's (1998) General Method of Moments (System GMM). This method is designed to get unbiased estimates of the coefficients while using a panel fixed-effects with a lagged dependent variable. The main regressions are done on the full sample (1977-2016). Subsample regressions are also done to check robustness and possible structural changes.

The results are shown in a standardized coefficient format in Table 1. A variable is standardized by subtracting its sample mean from its value and, then, dividing the difference by the corresponding sample standard deviation. This rescaling the variables forces them to have a mean of zero and standard deviation of one. In this way, one can compare the impact of each right-hand variable on the dependent variable because the units are the same. The results are reported for the downward and upward hollowing-out indices. 


\section{Downward Regressions}

Columns (1)-(3) and (7)-(9) in Table 1 show the coefficients for the regressions with the downward hollowing-out and population-share indices as the dependent variable, respectively. The results suggest that the level of the downward hollowing-out index in a state and year is:

- lower if the state's average age is higher. This is because age is a proxy for years of experience. Regression models give the right sign, but only some have statistical significance for the effect of average age on the downward polarization index. In other words, age does not turn out to be a very important driver of downward polarization, despite the unconditional correlation of it with polarization that we showed before. This is likely because other variables, which are used in the same regression models (e.g., education), explain polarization more strongly. Notwithstanding this result at the state level, in the next subsection, we'll confirm that age is significant for determining household incomesconsistent with the work of Mincer and others.

- lower if the state's average education level is higher. This is consistent with our priors that in the more educated states, the share of the low-income class is smaller.

- higher if on average the share of non-white household population is higher. This is also as expected given that the literature has shown that non-whites, ceteris paribus, have lower incomes.

- higher if the overall offshoring or routinization level of jobs in that state is higher. As explained before, offshoring and routinization levels are defined, respectively, as the inverse of the routinizability and offshorability scores. They capture the extent to which jobs in a state have already been offshored and routinized. Higher offshoring and routinization levels suggest that jobs in the state are already more offshored and, hence, there is higher income polarization.

- Table 1 does not include all the models and results. The full set of state-level results for the downward indices are reported in Appendix IV, Tables 3A and 3B. In addition to what was mentioned above, the results indicate that the level of the downward hollowing-out index in a state and year is:

- lower if the share of manufacturing jobs is higher in that state because manufacturing jobs, ceteris paribus, pay better. The share-of-manufacturing variable is correlated with routinization, and offshoring variables, likely because manufacturing jobs have been routinized and offshored notably more than non-manufacturing jobs. Therefore, one should be careful with the interpretation of the coefficients when the share-of-manufacturing variable is used in the same model as routinization or offshoring. We have separated these in different models in Appendix IV, Tables 3A and 3B.

- higher if on average the share of female-headed household population is higher. This is also as expected given that the literature has shown that females, ceteris paribus, have lower incomes. 


\begin{tabular}{|c|c|c|c|c|c|c|c|c|c|c|c|c|}
\hline & \multicolumn{3}{|c|}{$\begin{array}{l}\text { Hollowing-Out } \\
\text { Downward }\end{array}$} & \multicolumn{3}{|c|}{$\begin{array}{l}\text { Hollowing-Out } \\
\text { Upward }\end{array}$} & \multicolumn{3}{|c|}{$\begin{array}{c}\text { Population-Share } \\
\text { Downward }\end{array}$} & \multicolumn{3}{|c|}{$\begin{array}{c}\text { Population-Share } \\
\text { Upward }\end{array}$} \\
\hline & $1977-2016$ & $1977-2000$ & $2000-2016$ & $1977-2016$ & $1977-2000$ & $2000-2016$ & $1977-2016$ & $1977-2000$ & $2000-2016$ & $1977-2016$ & $1977-2000$ & $2000-2016$ \\
\hline Lagged dependent variable & $\begin{array}{l}0.19 * * * \\
(0.036)\end{array}$ & $\begin{array}{l}0.23^{* * *} \\
(0.045)\end{array}$ & $\begin{array}{l}0.15^{* * *} \\
(0.051)\end{array}$ & $\begin{array}{l}0.15^{* * *} \\
(0.034)\end{array}$ & $\begin{array}{l}0.18^{* * *} \\
(0.047)\end{array}$ & $\begin{array}{l}0.13^{* * *} \\
(0.038)\end{array}$ & $\begin{array}{l}0.14^{* * *} \\
(0.033)\end{array}$ & $\begin{array}{l}0.14^{* * *} \\
(0.044)\end{array}$ & $\begin{array}{l}0.12^{* * *} \\
(0.040)\end{array}$ & $\begin{array}{l}0.15^{* * *} \\
(0.034)\end{array}$ & $\begin{array}{l}0.19^{* * *} \\
(0.047)\end{array}$ & $\begin{array}{c}0.09 * \\
(0.048)\end{array}$ \\
\hline Household characteristics & & & & & & & & & & & & \\
\hline Age & $\begin{array}{l}-0.14^{*} \\
(0.079)\end{array}$ & $\begin{array}{l}-0.20^{* *} \\
(0.083)\end{array}$ & $\begin{array}{c}-0.07 \\
(0.103)\end{array}$ & $\begin{array}{c}-0.24^{* * *} \\
(0.062)\end{array}$ & $\begin{array}{c}-0.31 * * * \\
(0.086)\end{array}$ & $\begin{array}{l}-0.13^{*} \\
(0.070)\end{array}$ & $\begin{array}{l}-0.12 \\
(0.094)\end{array}$ & $\begin{array}{l}-0.21^{* *} \\
(0.097)\end{array}$ & $\begin{array}{c}-0.03 \\
(0.125)\end{array}$ & $\begin{array}{c}-0.26 * * * \\
(0.066)\end{array}$ & $\begin{array}{c}-0.31^{* * *} \\
(0.089)\end{array}$ & $\begin{array}{l}-0.17^{* *} \\
(0.068)\end{array}$ \\
\hline Education & $\begin{array}{c}-0.79 * * * \\
(0.126)\end{array}$ & $\begin{array}{c}-0.79 * * * \\
(0.113)\end{array}$ & $\begin{array}{c}-0.83^{* * *} \\
(0.205)\end{array}$ & $\begin{array}{c}-0.73 * * * \\
(0.127)\end{array}$ & $\begin{array}{c}-0.71^{* * *} \\
(0.125)\end{array}$ & $\begin{array}{c}-0.93 * * * \\
(0.163)\end{array}$ & $\begin{array}{c}-0.84 * * * \\
(0.132)\end{array}$ & $\begin{array}{c}-0.87^{* * *} \\
(0.115)\end{array}$ & $\begin{array}{c}-0.83^{* * *} \\
(0.238)\end{array}$ & $\begin{array}{c}-0.67 * * * \\
(0.132)\end{array}$ & $\begin{array}{c}-0.59 * * * \\
(0.127)\end{array}$ & $\begin{array}{c}-1.07^{* * *} \\
(0.184)\end{array}$ \\
\hline Share of non-white population & $\begin{array}{l}0.20^{* * *} \\
(0.068)\end{array}$ & $\begin{array}{l}0.19 * * * \\
(0.062)\end{array}$ & $\begin{array}{l}0.20^{* *} \\
(0.080)\end{array}$ & $\begin{array}{l}0.17^{* *} \\
(0.068)\end{array}$ & $\begin{array}{l}0.13^{*} \\
(0.077)\end{array}$ & $\begin{array}{l}0.22^{* * *} \\
(0.062)\end{array}$ & $\begin{array}{l}0.23^{* * *} \\
(0.068)\end{array}$ & $\begin{array}{l}0.26^{* * *} \\
(0.062)\end{array}$ & $\begin{array}{l}0.19^{* *} \\
(0.081)\end{array}$ & $\begin{array}{l}0.17^{* *} \\
(0.068)\end{array}$ & $\begin{array}{c}0.14^{*} \\
(0.083)\end{array}$ & $\begin{array}{l}0.24 * * * \\
(0.057)\end{array}$ \\
\hline Job characteristics & & & & & & & & & & & & \\
\hline Offshoring & $\begin{array}{l}0.34 * * * \\
(0.082)\end{array}$ & $\begin{array}{l}0.31 * * * \\
(0.081)\end{array}$ & $\begin{array}{l}0.42^{* * *} \\
(0.105)\end{array}$ & $\begin{array}{l}0.28^{* * *} \\
(0.087)\end{array}$ & $\begin{array}{l}0.25^{* * *} \\
(0.097)\end{array}$ & $\begin{array}{l}0.39 * * * \\
(0.093)\end{array}$ & $\begin{array}{l}0.32^{* * *} \\
(0.082)\end{array}$ & $\begin{array}{l}0.30 * * * \\
(0.078)\end{array}$ & $\begin{array}{l}0.39 * * * \\
(0.119)\end{array}$ & $\begin{array}{l}0.26 * * * \\
(0.087)\end{array}$ & $\begin{array}{l}0.22 * * \\
(0.098)\end{array}$ & $\begin{array}{l}0.43^{* * *} \\
(0.097)\end{array}$ \\
\hline Routinization & $\begin{array}{l}0.25 * * * \\
(0.065)\end{array}$ & $\begin{array}{l}0.23^{* * *} \\
(0.070)\end{array}$ & $\begin{array}{l}0.24^{* * *} \\
(0.085)\end{array}$ & $\begin{array}{l}0.23^{* * *} \\
(0.074)\end{array}$ & $\begin{array}{l}0.20^{* * *} \\
(0.076)\end{array}$ & $\begin{array}{l}0.27^{* * *} \\
(0.086)\end{array}$ & $\begin{array}{l}0.22^{* * *} \\
(0.071)\end{array}$ & $\begin{array}{l}0.19 * * \\
(0.079)\end{array}$ & $\begin{array}{l}0.22^{* *} \\
(0.090)\end{array}$ & $\begin{array}{l}0.21^{* * *} \\
(0.077)\end{array}$ & $\begin{array}{l}0.15^{* *} \\
(0.074)\end{array}$ & $\begin{array}{l}0.32^{* * *} \\
(0.104)\end{array}$ \\
\hline Constant & $\begin{array}{l}0.96 * * * \\
(0.164)\end{array}$ & $\begin{array}{l}0.31 * * * \\
(0.104)\end{array}$ & $\begin{array}{l}0.32 * * * \\
(0.115)\end{array}$ & $\begin{array}{c}-1.61 * * * \\
(0.191)\end{array}$ & $\begin{array}{l}0.32 * * * \\
(0.113)\end{array}$ & $\begin{array}{l}1.01^{* * *} \\
(0.141)\end{array}$ & $\begin{array}{c}-1.56^{* * *} \\
(0.218)\end{array}$ & $\begin{array}{c}0.10 \\
(0.119)\end{array}$ & $\begin{array}{l}1.06 * * * \\
(0.234)\end{array}$ & $\begin{array}{c}-1.39 * * * \\
(0.195)\end{array}$ & $\begin{array}{c}-1.37^{* * *} \\
(0.208)\end{array}$ & $\begin{array}{l}1.14^{* * *} \\
(0.161)\end{array}$ \\
\hline Observations & 1,989 & 1,173 & 867 & 1,989 & 1,173 & 867 & 1,989 & 1,173 & 867 & 1,989 & 1,173 & 867 \\
\hline Number of states & 51 & 51 & 51 & 51 & 51 & 51 & 51 & 51 & 51 & 51 & 51 & 51 \\
\hline AR(2) p-value & 0.744 & 0.879 & 0.472 & 0.540 & 0.721 & 0.863 & 0.561 & 0.187 & 0.274 & 0.658 & 0.853 & 0.636 \\
\hline Sargan $p$-value & 0.657 & 0.001 & 0.020 & 0.794 & 0.000 & 0.003 & 0.728 & 0.000 & 0.033 & 0.582 & 0.001 & 0.004 \\
\hline
\end{tabular}




\section{Upward Regressions}

Columns (4)-(6) and (10)-(12) of Table 1 show the coefficients for the regressions with the upward hollowing-out and population-share indices as the dependent variables, respectively. The full set of results are reported in Appendix IV, Tables 4A and 4B. Comparing the upward regressions with the downward regressions discussed before shows that the drivers of the upward income polarization are like those of the downward income polarization with two differences:

- Age's role is stronger in driving the upward polarization. In other words, at the top of the income distribution, experience matters more than at the bottom.

- For all the right-hand side variables, except age, the coefficient sizes are larger for the downward polarization in the pre-2000 sample regressions, but larger for the upward polarization in the post-2000 sample regressions. This says that pre-2000, higher education relatively benefited low-income households more and international trade and job routinization hurt their incomes relatively more than the high-income households. This was flipped post-2000, during which, higher education relatively benefited low-income households less and international trade and job routinization hurt their incomes relatively less than the high-income households.

Beyond these differences, which are quantitatively marginal, the drivers of upward income polarization are like those of the downward polarization.

The result that the drivers of downward and upward income polarization are practically the same at first might look very surprising. How is it possible that the same variables explain the dropping of the middle class to low-income ranks as well as the rising of the middle class to high-income ranks? It is easier to address this question using the population-share index. For example, let's consider education, which is a determinant of income polarization. Higher education in general would improve the income of any household from any income class, but disproportionately improves low-income households' incomes. Therefore, with higher education, more households from the low-income ranks join the middle-income ranks, than those who move from the middle-income ranks to high-income ranks. Noting that population sizes of different classes are relative to the total and always add up to 1, more education leads to a relatively larger middle-income class and smaller low- and high-income classes, leading to a decrease in both downward and upward population-share indices. A similar argument could be made for other determinants of polarization, which would at the same time affect both the downward and upward polarizations.

\section{Contributions}

We are now able to calculate the contributions of each independent variable to the change in the downward and upward hollowing-out indices, using the estimated coefficients in Table 1. The results are reported in Figure 14A. ${ }^{14}$ The columns in Figure 14A are reported in the same order as the corresponding regression in Table 1.

\footnotetext{
${ }^{14}$ Appendix IV, Figures 3A, 3B, 4A, and 4B show the contributions for all of the models reported in Appendix IV, Tables 3A, 3B, 4A, and 4B.
} 
The left panel shows the contributions to the rise in the downward income hollowing-out index for the full sample over 1977-2016, as well as the pre- and post-2000 subsamples. More than half of the increase in the downward polarization index is explained by technology and international trade. The very left chart of Figure 14A shows that the downward hollowing-out index grew by about 26 percent during 1977-2016. Job routinization and offshoring are responsible for about 15 percentage points of this increase, each bearing roughly half of this contribution. The remaining 11 percentage points in the increase in the index during this period are due to all other factors, which include persistence of the dependent variable and the time fixed-effect minus the countervailing effects from the individual characteristics, most notably higher education. ${ }^{15}$ The left panel of Figure 14A also reports the contributions for the subsamples (1977-2000 and 2000-2016). Relative contributions of technology, trade, and other factors are broadly similar in the subsamples and the full sample, reflecting robustness of the results and the fact that the drivers of downward income polarization have broadly remained similar over the past four decades.

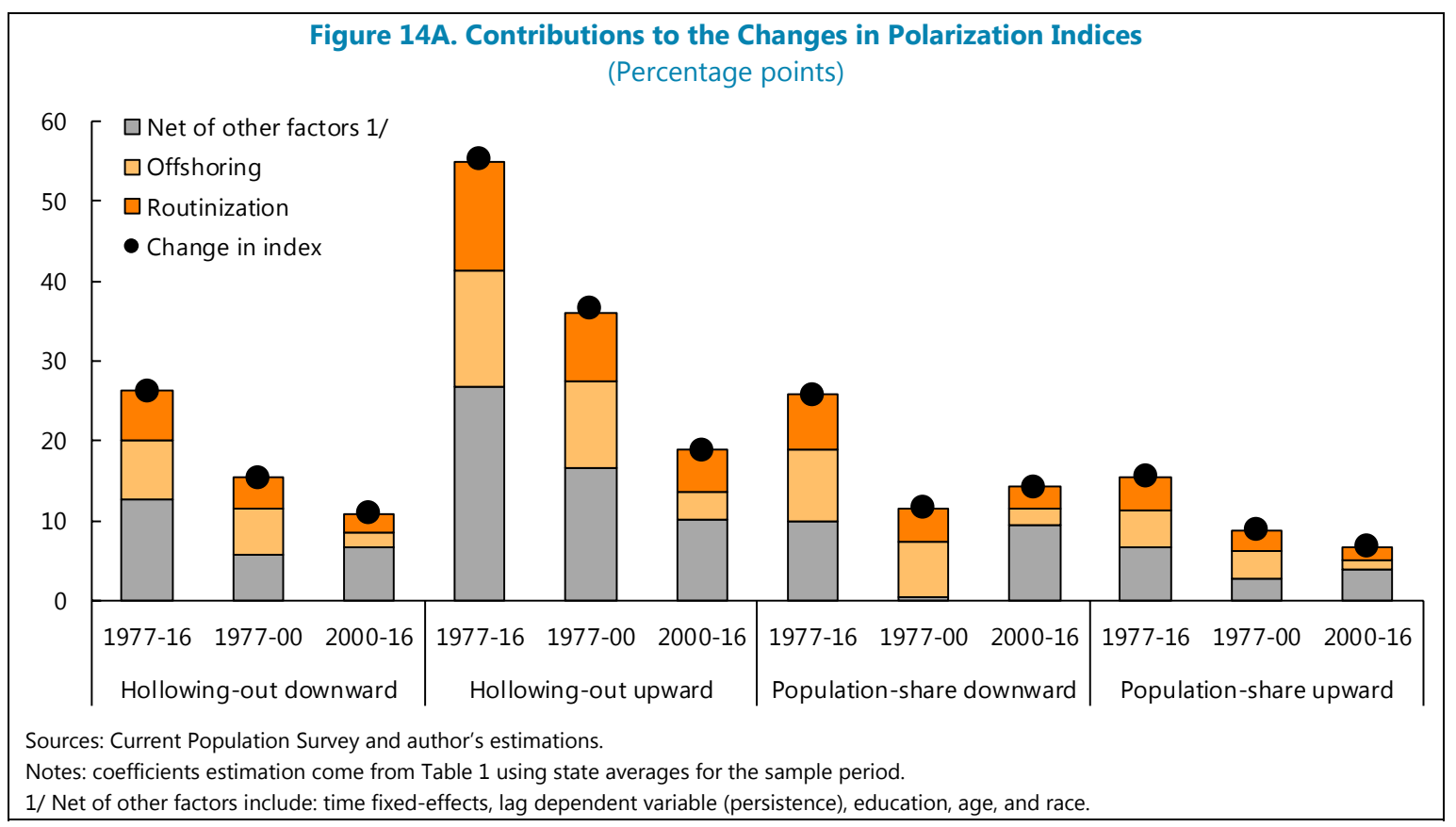

The second panel from left in Figure 14A shows contributions of different factors to upward hollowing out, in the same way that the left panel shows for downward hollowing out. The upward hollowing-out index grew by about 56 percent during 1977-2016. Job routinization and offshoring are responsible for about 30 percentage points of this increase, each bearing roughly half of this contribution. The remaining 26 percentage points in the increase in the index during this period are due to the other factors, including the persistence of the dependent variable and the time fixed-effect minus the countervailing effects from the individual characteristics, most notably higher education. This panel also shows similar results for the subsamples (1977-2000 and 2000-2016) as in the full sample. Comparing the left and second-from-left panels of Figure $14 \mathrm{~A}$, one can easily see that qualitatively, the channels of downward and upward income

${ }^{15}$ These are broken down in Figure 14B. 
hollowing out are similar and quantitatively, upward hollowing out and its contributors are roughly double the size of downward hollowing out.

The two right panels of Figure 14A report the contributions of different variables for the corresponding regressions in Table 1, in which the dependent variables are the downward and upward population-share indices. This is to ensure robustness of our conclusions about the channels of downward income polarization to the choice of the polarization index. The contributions to the population-share indices are similar to those of the hollowing-out indices (explained above) qualitatively. The downward hollowing-out and population-share indices, in addition, are also in the same ballpark quantitatively. For the upward, however, contributions of all factors to the hollowing-out index are about double the size of the population-share index. This is simply because in the upward hollowing-out index the income size effects are large, but this factor does not play any role in the population-share index.

Returning to the contributors to income polarization other than international trade and technology, Figure 14B provides a break down. The time effects have significantly increased the hollowing-out and population-share indices. Household characteristics, particularly education, have played an important role, with their effect towards the direction of lowering the downward hollowing-out index. On net, these components have contributed to less than half of the increased polarization in the full and subsamples shown in Figure 14A.

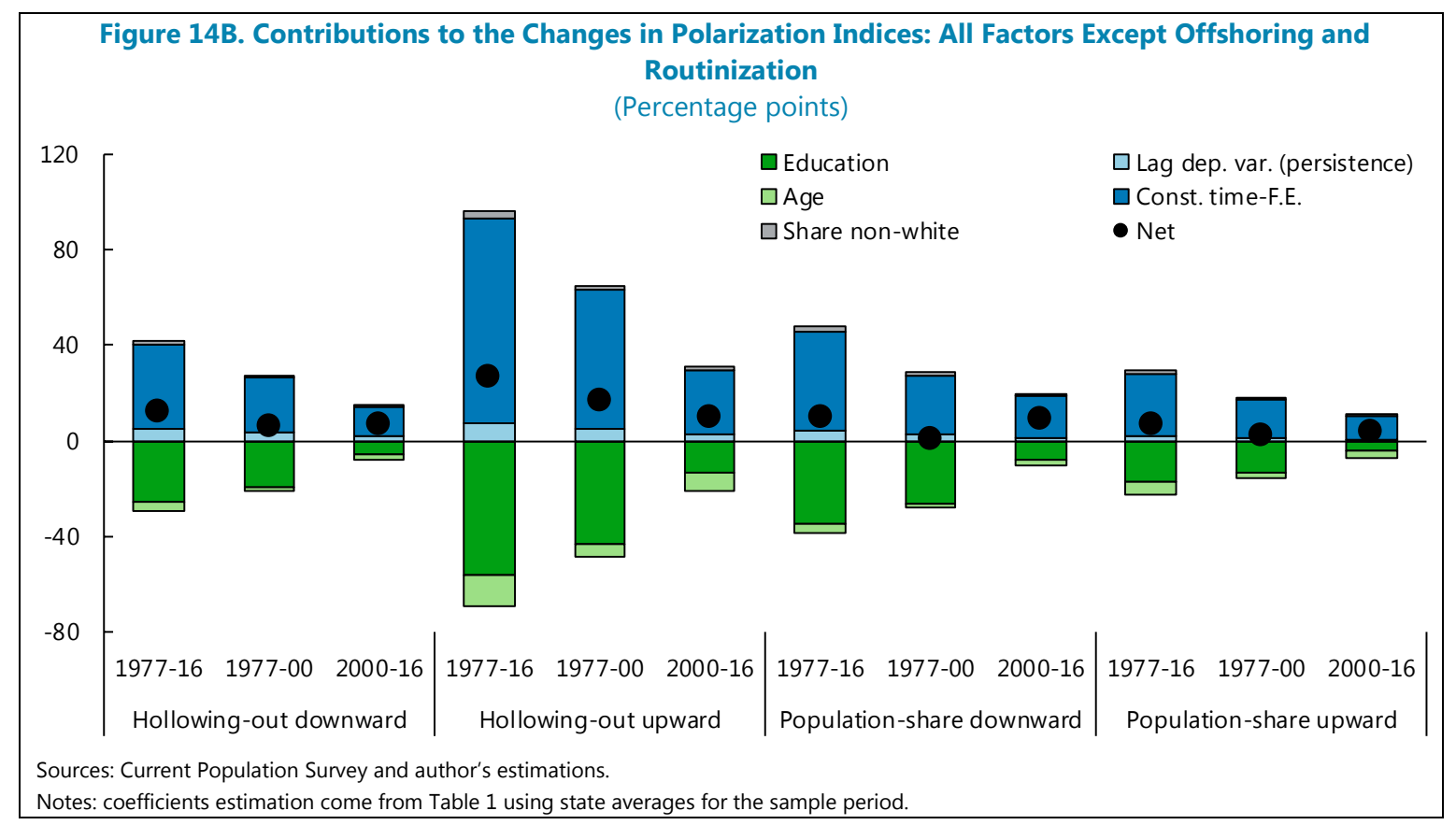

The state-level regressions are our main results. In the next section, we do household-level regressions, as robustness check for the channels of income polarization. 


\section{B. Household-level Regressions}

In this subsection, we take advantage of the micro structure of our data and run regressions at the household level. These regressions do not help us find the determinants of income polarization per se, but provide good guidance on the determinants of households' incomes compared to their state's median. The dependent variable for each household is the household's income normalized by the median in each state and year. This ratio captures how far a household's income is from the median, and hence, can be interpreted as an indicator for income polarization at the household level. The household regression model is as follows:

$$
\frac{y_{t}^{i, s}}{y_{t}^{M, s}}=c+\mathrm{B} * X_{t}^{i, s}+D * Z_{t}^{i, s}+\varepsilon_{t}^{i, s}
$$

Where, $y_{t}^{i, s}$ is the real size-adjusted income of household $i$ in state $s$ in year $t ; y_{t}^{M, s}$ is the median real size-adjusted income in state $s$ in year $t ; c$ is the constant; $X_{t}^{i, s}$ is the vector of the household's characteristics (age, gender, and education); $B$ is the vector of coefficients for the household characteristics; $Z_{t}^{i, s}$ is the vector of job characteristics (technology and tradability); $D$ is the vector of coefficients for job characteristics; and, finally, $\varepsilon_{t}^{i, s}$, is the residual of this estimation. The residual is the portion of the household income that is not explained by its own characteristics nor by its job characteristics.

We estimate the equation using both ordinary least squares (OLS) and quantile regression methods, i.e., on the mean, median and the $25^{\text {th }}$ and $75^{\text {th }}$ quantiles. ${ }^{16}$ If the distribution of the dependent variable has large outliers or is skewed, a regression around the median is the best estimation to capture the central tendency of the data, and is more robust than the OLS regression (around the mean), and unlike OLS, it does not assume any special distribution of the residuals. Finally, we run this regression on the pooled sample, imposing that coefficients be the same across states and time.

Table 2 reports a summary of the regression results using the OLS with standardized coefficients, while Appendix V, Tables 5A and 5B report the full results. In Table 2, column (1) shows the OLS regression results for the full sample over 1968-2016 and columns (2)-(3) show the results for the pre- and post-2000 subsamples as a check for stability of the coefficients. Column (4) breaks the sample to include the low- and middle-income households, but exclude the high-income households. Finally, column (5) breaks the sample to include the middle- and high-income households, but exclude the low-income households. Columns (4)-(5) serve as additional robustness check to ensure that the results reported in column (1) are not driven by either extreme side of the income distribution.

The full-sample results in column (1) are consistent with what one would expect. A household's income, relative to the median, increases with age (proxy for experience), education, and if the household head is male. In addition, if the household head works in the manufacturing sector, the household's income is greater and high-tech jobs make more income than low-tech jobs.

\footnotetext{
${ }^{16}$ While OLS estimates the coefficients by minimizing the sum of squared residual, the quantile regression minimizes the sum of the absolute residuals. Since this function is not differentiable, the objective function is defined as a linear programming problem and solved using the simplex algorithm. See Koenker, R. and K.F. Hallock (2001) and the references within.
} 
Finally, if the household head works in a job that is more offshorable and routinizable, his/her salary is lower.

The sub-sample results in columns (2)-(3) confirm that while all coefficients in general have the same sign pre- and post-2000, coefficients have been somewhat stronger post-2000 compared to pre-2000.

Columns (4)-(5), however, indicate that the results reported in column (1) are heavily biased by the high-income households: column (5) that excludes the low-income households is very similar to column (1), whereas column (4) that exclude the high-income households is very different from column (1). We conclude that while regressions in Table 1 have the expected signs, they are not quantitatively an accurate reflection of determinants of income for all income groups. For this reason, we'll next switch to quantile regressions to more accurately estimate the coefficients for different income groups.

\begin{tabular}{|c|c|c|c|c|c|c|}
\hline \multicolumn{7}{|c|}{$\begin{array}{l}\text { Table 2. Household-level Regressions (OLS; Standardized Coefficients) 1/ } \\
\text { Dependent Variable: Real Size-Adjusted Household Income Relative to the Annual State Median (1968-2016) 2/ }\end{array}$} \\
\hline & & $\begin{array}{c}\text { (1) } \\
\text { Y(h)/Y.Med } \\
\text { Full sample } \\
\text { OLS }\end{array}$ & $\begin{array}{c}\text { (2) } \\
\text { Y(h)/Y.Med } \\
\text { 1977-1999 } \\
\text { OLS }\end{array}$ & $\begin{array}{c}\text { (3) } \\
\text { Y(h)/Y.Med } \\
2000-2015 \\
\text { OLS }\end{array}$ & $\begin{array}{c}\text { (4) } \\
\text { Y(h)/Y.Med } \\
\text { Full sample } \\
\text { excl. high } \\
\text { OLS }\end{array}$ & $\begin{array}{c}\text { (5) } \\
\text { Y(h)/Y.Med } \\
\text { Full sample } \\
\text { excl. low } \\
\text { OLS }\end{array}$ \\
\hline \multirow[t]{5}{*}{ Regression Set 1} & Age & $\begin{array}{l}0.14^{\star \star \star} \\
(0.000)\end{array}$ & $\begin{array}{l}0.13^{\star \star *} \\
(0.000)\end{array}$ & $\begin{array}{l}0.16^{\star \star *} \\
(0.000)\end{array}$ & $\begin{array}{l}0.03^{* * *} \\
(0.000)\end{array}$ & $\begin{array}{l}0.14^{\star \star \star} \\
(0.000)\end{array}$ \\
\hline & Gender $($ male $=1)$ & $\begin{array}{l}0.13^{\star \star \star} \\
(0.000)\end{array}$ & $\begin{array}{l}0.11^{\star \star \star} \\
(0.000)\end{array}$ & $\begin{array}{l}0.14^{\star \star \star} \\
(0.000)\end{array}$ & $\begin{array}{l}0.04^{\star \star \star} \\
(0.000)\end{array}$ & $\begin{array}{l}0.13^{\star \star \star} \\
(0.000)\end{array}$ \\
\hline & Education & $\begin{array}{l}0.19^{\star \star \star \star} \\
(0.000)\end{array}$ & $\begin{array}{l}0.16^{\star \star \star} \\
(0.000)\end{array}$ & $\begin{array}{l}0.28^{\star \star \star} \\
(0.000)\end{array}$ & $\begin{array}{l}0.05^{\star \star \star} \\
(0.000)\end{array}$ & $\begin{array}{l}0.18^{\star \star \star} \\
(0.000)\end{array}$ \\
\hline & Share of non-white population & $\begin{array}{c}-0.03^{\star \star \star} \\
(0.000)\end{array}$ & $\begin{array}{c}-0.03^{\star \star \star} \\
(0.000)\end{array}$ & $\begin{array}{l}-0.03^{* * *} \\
(0.000)\end{array}$ & $\begin{array}{c}-0.02^{\star \star \star} \\
(0.000)\end{array}$ & $\begin{array}{c}-0.02^{\star \star \star} \\
(0.000)\end{array}$ \\
\hline & Offshorability score & $\begin{array}{l}-0.06^{\star \star *} \\
(0.000)\end{array}$ & $\begin{array}{l}-0.06^{* \star *} \\
(0.000)\end{array}$ & $\begin{array}{l}-0.07^{* * *} \\
(0.000)\end{array}$ & $\begin{array}{l}-0.01^{* \star *} \\
(0.000)\end{array}$ & $\begin{array}{l}-0.06^{* \star *} \\
(0.000)\end{array}$ \\
\hline Regression Set $2 / 3$ & Routinizability score & $\begin{array}{l}-0.04^{\star \star \star} \\
(0.000)\end{array}$ & $\begin{array}{l}-0.03^{\star * *} \\
(0.000)\end{array}$ & $\begin{array}{l}-0.04^{\star \star \star} \\
(0.000)\end{array}$ & $\begin{array}{l}0.00^{\star \star \star} \\
(0.000)\end{array}$ & $\begin{array}{l}-0.04^{\star \star *} \\
(0.000)\end{array}$ \\
\hline $\begin{array}{c}\text { Regression Set } 3 \\
\text { Manufacturing } / 3\end{array}$ & Manufacturing $(=1)$ & $\begin{array}{l}0.04^{\star \star \star} \\
(0.000)\end{array}$ & $\begin{array}{l}0.03^{\star \star \star} \\
(0.000)\end{array}$ & $\begin{array}{l}0.04^{\star \star \star} \\
(0.000)\end{array}$ & $\begin{array}{l}0.03^{\star \star \star} \\
(0.000)\end{array}$ & $\begin{array}{l}0.02^{\star \star \star} \\
(0.000)\end{array}$ \\
\hline & Technology (High tech. $=1)$ & $\begin{array}{l}0.02^{\star \star \star} \\
(0.000)\end{array}$ & $\begin{array}{l}0.02^{\star \star \star} \\
(0.000)\end{array}$ & $\begin{array}{l}0.02^{\star \star \star} \\
(0.000)\end{array}$ & $\begin{array}{l}0.01^{\star * \star} \\
(0.000)\end{array}$ & $\begin{array}{l}0.01^{\star \star \star} \\
(0.000)\end{array}$ \\
\hline Regression Set 4 & Technology (Medium-high tech.=1) & $\begin{array}{l}0.02^{* \star *} \\
(0.000)\end{array}$ & $\begin{array}{l}0.02^{* * *} \\
(0.000)\end{array}$ & $\begin{array}{l}0.02^{\star \star \star *} \\
(0.000)\end{array}$ & $\begin{array}{l}0.02^{\star * *} \\
(0.000)\end{array}$ & $\begin{array}{l}0.01^{* * *} \\
(0.000)\end{array}$ \\
\hline Technology /3/4 & Technology (Medium-low tech. $=1$ ) & $\begin{array}{l}0.01^{\star \star \star} \\
(0.000)\end{array}$ & $\begin{array}{l}0.01^{\star \star \star} \\
(0.000)\end{array}$ & $\begin{array}{l}-0.00^{* \star *} \\
(0.000)\end{array}$ & $\begin{array}{l}0.01^{\star \star \star} \\
(0.000)\end{array}$ & $\begin{array}{l}0.00^{\star \star \star} \\
(0.000)\end{array}$ \\
\hline & Technology $($ Low tech. $=1)$ & $\begin{array}{l}0.01^{\star \star \star} \\
(0.000)\end{array}$ & $\begin{array}{l}0.01^{\star \star \star} \\
(0.000)\end{array}$ & $\begin{array}{l}-0.00^{* \star \star} \\
(0.000)\end{array}$ & $\begin{array}{l}0.01^{\star \star \star} \\
(0.000)\end{array}$ & $\begin{array}{l}0.00^{\star \star \star} \\
(0.000)\end{array}$ \\
\hline \multicolumn{7}{|c|}{$\begin{array}{l}\text { Sources: Current Population Survey and author's estimations. } \\
\text { 1/ Regressions include same independent variables for household heads and second adults in the household (relative). However, in this } \\
\text { table only coefficients for household heads are reported. Full set of coefficients are reported in Appendix V, Tables 5A and 5B. } \\
\text { 2/ Income data is size-adjusted using OECD's equivalence scale. This methodology assigns a value of } 1 \text { to the first household member, } \\
0.7 \text { to each additional adult, and } 0.5 \text { to each child. We use the consumer price index (CPI) at the national level to deflate the income series } \\
\text { into the real size-adjusted income. } \\
3 \text { / Like regression set } 1 \text {, regression sets } 2 \text { and } 3 \text { also include a household characteristics consisting of age, gender and education. Full } \\
\text { report of the estimations is reported in Appendix } V \text {, Tables } 5 \mathrm{~A} \text { and } 5 \mathrm{~B} \text {. } \\
\text { 4/ If household head's employment is in any sector other than manufacturing, all the four dummies are all set to zero. } \\
\text { Robust standard errors in parentheses, }{ }^{* * *} p<0.01,{ }^{* *} p<0.05,{ }^{*} p<0.1 \text {. }\end{array}$} \\
\hline
\end{tabular}


A summary of the quantile regression results are reported in Table 3, while Appendix V, Tables $6 \mathrm{~A}$ and $6 \mathrm{~B}$ report the full results. In Table 3, Columns (1)-(3) show the regression results for the lowest quantile for the full sample as well as the pre- and post-2000 subsamples. Columns (4)(6) show the results for the second quantile and columns (7)-(9) show the results for the third quantile. The third quantile regression results are very similar in size to those of the OLS, which were shown in Table 2, column 1. Table 3 confirms that drivers of income have indeed been those discussed in Tables 2, but shows that coefficients are different for the bottom and top of income distribution.

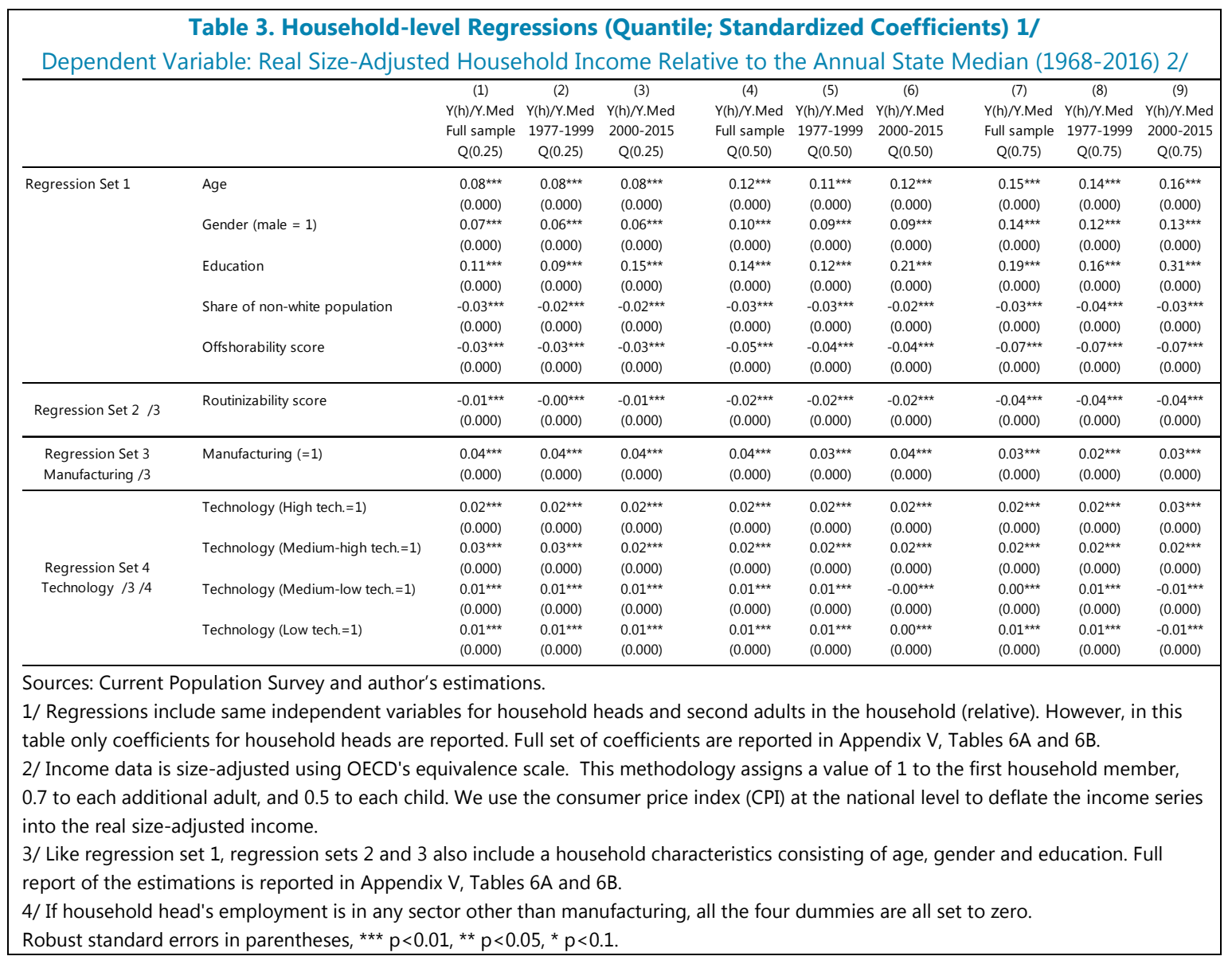

\section{CONCLUding Remarks}

Our work has contributed to the understanding of income polarization trends and their proximate causes in the United States.

We documented that income polarization has increased substantially over the last 4 decades at the U.S. state level, much the same as previous work has shown for the national level. While there are important variations across states, the middle-income class appears to have been generally hollowing out for a typical state.

An important fact that our work has shed light on is that richer states (defined in this paper as those with higher median household income levels) also have a larger middle-income class and smaller population share of the low- and high-income class households. In other words, richer states are less polarized. The smaller low-income population share is particularly interesting because it is not conceptually obvious as for such states the income cutoff for being low-income 
is higher. The fact that richer states are less polarized at the U.S. state level is an assuring complement for the well-known result in the literature that richer countries also have lower income inequality levels.

We developed two new indices of income polarization. These indices have profound economic rationales - directly relating to the sizes of the low-, middle-, and high-income classes, as well as variations in household incomes. In addition, unlike the traditional Wolfson index, these indices allow us to study the phenomenon of hollowing out of the middle class into both downward and upward directions.

We also designed and estimated state- and household-level regression models to find the proximate causes of income polarization. The results suggest that technology, measured by job routinization, and international trade, measured by job offshoring, can explain more than half of the rise in income polarization, with broadly equal contributions. Household characteristics, including age, education, race, and gender have also been important drivers but on net have had a countervailing effect on income polarization. This is mainly thanks to the rising education level of households, which has led to better incomes.

Returning to the finding that the routinization of tasks and international competition have accounted for around one-third of the income polarization seen over the past 40 years. This should not be misinterpreted that technological change and globalization have been overall "bad". The evidence is these have generated higher living standards and boosted productivity and growth. This is, however, a finding that these positive forces have had important side-effects on the income distribution and household welfare that need to be carefully understood and mitigated. While proposing specific policies is beyond the scope of our work, these could potentially include access to better education, family-friendly benefits, skill-based immigration, etc.

A drawback of our work, like most other contributions, is that our income data from the CPS is the pre-tax income. Future work could attempt to make use of ongoing studies that are trying to produce post-tax household income data through combining the CPS data with data from the Internal Revenue System. In addition, there are important missing explanatory variables in our work for polarization across states, which future work can include. These include the states' fiscal policy variables, infrastructure, and regulation.

We also look forward to seeing our polarization indices applied to household income data of other countries and our empirical models used to study the channels of income polarization in those countries. 


\section{References}

Abdih, Yasser, and Stephan Danninger, 2017, "What Do Industry and State Data Tell Us About the Decline of the U.S. Labor Share?" IMF working Paper No. 17/167 (Washington:

International Monetary Fund).

Alichi, Ali, Korey Kantenga, and Juan Solé, 2016, "Income Polarization in the United States," IMF Working Paper No. 16/121.

Alvaredo, Facundo, Anthony B. Atkinson, Thomas Piketty and Emmanuel Saez, 2015, The World Top Incomes Database, http://topincomes.g-mond.parisschoolofeconomics.eu/, Accessed 9/3/2015.

Arellano, M., and S. Bond, 1991, "Some Test of Specification for Panel Data: Monte Carlo Evidence and an Application to Employment Equations," Review of Economic Studies, 58(2), pp. 277-97.

Arrondel, Luc, Pierre Lamarche and Frédérique Savignac, 2015, "Wealth Effects on Consumption across the Wealth Distribution: Empirical Evidence," Working Paper Series 1817, European Central Bank.

Autor, David H., Lawrence F. Katz and Melissa S. Kearney, 2006, "The Polarization of the U.S. Labor Market," American Economic Review, 96(2), 189-94.

Autor, David H., Lawrence F. Katz and Melissa S. Kearney, 2008, "Trends in U.S. Wage Inequality: Revising the Revisionists," The Review of Economics and Statistics, 90(2), $300-23$.

Blundell, Richard and Stephan Bond, 1998, "Initial Conditions and Moment Restrictions in Dynamic Panel Data Models,” Journal of Econometrics, 87(1), 115-43.

Blundell, Richard, Luigi Pistaferri, and Ian Preston, 2008, "Consumption Inequality and Partial Insurance," American Economic Review, 98(5), 1887-1921.

Blundell, Richard, Luigi Pistaferri, and Itay Saporta-Eksten, 2014, "Consumption Inequality and Family Labor Supply,” Working Paper Series 1656, European Central Bank (London: European Central Bank).

Board of Governors of the Federal Reserve System, 2014, "Changes in U.S. Family Finances from 2010 to 2013: Evidence from the Survey of Consumer Finances," Federal Reserve Bulletin, 100(4).

Boehm, Michael J., 2013, "Has Job Polarization Squeezed the Middle Class? Evidence from the Allocation of Talents," CEP Discussion Papers dp1215, Centre for Economic Performance, LSE.

Browning, Martin, Mette Gørtz and Søren Leth-Petersen, 2013, "Housing Wealth and Consumption: A Micro Panel Study,” Economic Journal, Vol. 123, Issue 568, pp.401-28.

Carroll, Christopher D., 2009, "Precautionary Saving and the Marginal Propensity to Consume out of Permanent Income,” Journal of Monetary Economics, 56(6), 780-90. 
Carroll, Christopher D., Misuzu Otsuka, and Jiri Slacalek, 2011, "How Large Are Housing and Financial Wealth Effects? A New Approach," Journal of Money, Credit and Banking, 43(1), 55-79.

Carroll, Christopher D., Jiri Slacalek, and Kiichi Tokuoka, 2014, "The Distribution of Wealth and the Marginal Propensity to Consume," Working Paper Series 1655, European Central Bank.

Carroll, Christopher D., Jiri Slacalek, Kiichi Tokuoka, and Matthew White, 2015, "The Distribution of Wealth and the Marginal Propensity to Consume," Working Paper.

Christelis, Dimitris, Dimitris Georgarakos, and Tullio Jappelli, 2015, "Wealth shocks, unemployment shocks and consumption in the wake of the Great Recession," Journal of Monetary Economics, 72(C), 21-41.

Duclos, Jean-Yves, Joan Esteban, and Debraj Ray, 2004, "Polarization: Concepts, Measurement, Estimation," Econometrica, Volume 72, Issue 6, November 2004, pp. 1737-72.

Esteban, Joan and Debraj Ray, 2007, "A Comparison of Polarization Measures," UFAE and IAE Working Papers, 700.07.

Esteban, Joan and Debraj Ray, 2012, "Comparing Polarization Measures," The Oxford Handbook of the Economics of Peace and Conflict, April 2012.

Foster, James and Michael Wolfson, 2010, "Polarization and the decline of the middle class: Canada and the U.S.," Journal of Economic Inequality, 8(2), 247-73.

Goos Maarten and Alan Manning, 2007, "Lousy and Lovely Jobs: The Rising Polarization of Work in Britain," The Review of Economics and Statistics, 89(1), 118-33.

Gouskova, Elena, Patricia Andreski, and Robert F. Schoeni, 2010, "Comparing Estimates of Family Income in the Panel Study of Income Dynamics and the March Current Population Survey, 1968-2007," PSID Technical Series Paper \#10-01.

Greenwood, Jeremy, Nezih Guner, Georgi Kocharkov, and Cezar Santos, 2014, "Marry Your Like: Assortative Mating and Income Inequality,” NBER Working Paper No. 19829.

Heathcote, Jonathan, Fabrizio Perri and Giovanni L. Violante, 2010a, "Unequal We Stand: An Empirical Analysis of Economic Inequality in the United States: 1967-2006," Review of Economic Dynamics, 13(1), 15-51.

Heathcote, Jonathan, Kjetil Storesletten and Giovanni L. Violante, 2010b, "The Macroeconomic Implications of Rising Wage Inequality in the United States," Journal of Political Economy, 118(4), 681-722.

Jappelli, Tullio and Luigi Pistaferri, 2014, "Fiscal Policy and MPC Heterogeneity," American Economic Journal: Macroeconomics, 6(4), 107-136.

Li, Geng, Robert F. Schoeni, Sheldon Danziger, and Kerwin Kofi Charles, 2010, "New expenditure data in the PSID: comparisons with the CE," Monthly Labor Review 133(2): 335-60.

King, Miriam, Steven Ruggles, J. Trent Alexander, Sarah Flood, Katie Genadek, Matthew B. Schroeder, Brandon Trampe, and Rebecca Vick, 2010. Integrated Public Use Microdata 
Series, Current Population Survey: Version 3.0. (Machine-readable database). Minneapolis: University of Minnesota.

Koenker, Roger and Kevin F. Hallock, 2001, “Quantile Regression,” Journal of Economic Perspectives, 15(4), 14-56.

Kohler Ulrich, 2015, "PSIDTOOLS: Stata module to facilitate access to Panel Study of Income Dynamics (PSID)," Statistical Software Components S457951, Boston College, Department of Economics.

Krueger, Dirk, Kurt Mitman, and Fabrizio Perri, 2015, "Macroeconomics and Heterogeneity, including Inequality," Handbook of Macroeconomics (forthcoming).

McCarthy, Jonathan, 1995, "Imperfect insurance and differing propensities to consume across households," Journal of Monetary Economics, 36(2), 301-27.

Mian, Atif, Kamalesh Rao and Amir Sufi, 2013, "Household Balance Sheets, Consumption, and the Economic Slump,” The Quarterly Journal of Economics, 128(4), 1687-1726.

Mishel, Lawrence, John Schmitt, and Heidi Shierholz, 2013, “Assessing the job polarization explanation of growing wage inequality," Economic Policy Institute, Working Paper.

Panel Study of Income Dynamics, Public Use Dataset, 2015, Produced and distributed by the Survey Research Center, Institute for Social Research, University of Michigan, Ann Arbor.

Parker, Jonathan A., Nicholas S. Souleles, David S. Johnson, and Robert McClelland, 2013, "Consumer Spending and the Economic Stimulus Payments of 2008," American Economic Review, 103(6), 2530-53.

Pew Research Center, 2015, "The American Middle Class Is Losing Ground: No longer the majority and falling behind financially." Washington, D.C.: December.

Rose, Stephen J., 2016, “The Growing Size and Incomes of the Upper Middle Class.” Research Report, Urban Institute.

Schaffer, Mark E, 2005, "XTIVREG2: Stata module to perform extended IV/2SLS, GMM and AC/HAC, LIML and k-class regression for panel data models," Statistical Software Components S456501, Boston College Department of Economics.

Souleles, Nicholas S., 1999, "The Response of Household Consumption to Income Tax Refunds," American Economic Review, 89(4), 947-58.

Survey of Consumer Finances, 2015. Produced and distributed by the Board of Governors of the Federal Reserve System.

UNCTAD (2002) Trade and Development Report, Annex 1 to Chapter III.

Wolfson, Michael C., 1994, "When Inequalities Diverge," American Economic Review, 84(2), $353-58$. 


\section{Appendix I. Data}

The variables used in this paper consist of: the real size-adjusted household income, age, gender, education, race, employment sector, technology content, and routinizability and offshorability of household jobs. The data is at the household level at the annual frequency from the Current Population Survey (CPS). In the rest of this section we describe all the variables:

\section{Household-level Data}

- Real, size-adjusted household income. We start with the nominal income data, which is pre-tax at the household level. We make this data size-adjusted using OECD's equivalence scale. ${ }^{1}$ This methodology assigns a value of 1 to the first household member, 0.7 to each additional adult, and 0.5 to each child. In addition, we use the consumer price index (CPI) to deflate the income series into the real size-adjusted household income. ${ }^{2}$ We restrict our sample to households whose heads are 24-64 years old and have a nominal income (before size-adjustment) of at least $\$ 2$ per day. ${ }^{3}$

- Age. We have two variables for age: the age of the household head and the age of the second adult in the household (referred to as "relative"; in majority of cases spouse or partners).

- Education. We have two variables for education, one for the household head and one for the second adult in the household. These are years of schooling of each.

- Race. This is captured by two dummies for the household head and the second adult in the household. The respective dummies are set to 1 for those who are white and zero for others.

- Gender. This is captured by two dummies for the household head and the second adult in the household. The respective dummies are set to 1 for those who are male and zero for females.

- Manufacturing. This is captured by two dummies for the household head and the second adult in the household. The respective dummies are set to 1 for those with manufacturing jobs and zero for others.

- Technology. We identify technology with four dummies based on UNCTAD ${ }^{4}$ classification, which is also adopted by the OECD and European Union (Eurostat). If a household head's job is high tech, medium-high tech, medium-low tech, or low tech in the manufacturing sector, the respective dummy take a value of 1 and 0 otherwise. If the household's job is not

\footnotetext{
${ }^{1}$ Adjustment for household size is a norm in the literature based on the notion that there are economies of scale for household incomes and expenditures, e.g., the rental value of a two-bedroom apartment, ceteris paribus, is normally less than double the rental value of a one-bedroom apartment. Nonetheless, we also examined the series without adjustment for household size (not reported) and confirmed a similar qualitative general result that polarization has increased notably over the past four decades.

${ }^{2}$ We have done various robustness tests (not reported) and concluded that using the personal consumption expenditure (PCE) deflator instead of the consumer price index (CPI) deflator would not qualitatively change any of our results. This is because the cutoffs for definitions of the middle class (50-150 percent of median income) are relatively large, as compared to the inequality literature, which at time is concerned about a narrow range of incomes, such as 0.1 percent highest incomes.

${ }^{3}$ See a full description of our sample restrictions in the Data Appendix.

${ }^{4}$ See United Nations Conference on Trade and Development (UNCTAD; 2002), Trade and Development Report, Annex 1 to Chapter III.
} 
in manufacturing, all the four dummies are set to zero. We also include similar dummies for the second adult in the household.

- Routinizability and offshorability scores. These data are constructed using the same methodology as Abdih and Danninger (2017), following Autor and Dorn (2013) and Firpo et al. (2011) and are based on the CPS data and the U.S. Department of Labor' Occupational Information Network (O*NET) for 1990-2016.

- Routinizability score. Captures the propensity to automate routine tasks. It is constructed using the following O*NET variables: "degree of automation"; "importance of repeating same tasks"; "structured versus unstructured work"; "pace determined by speed of equipment"; and "spend time making repetitive motions." Each occupation has a score for each of these variables; these are aggregated to form a composite routinizability score for each occupation. We assign to every household a routinizability score equal to this index for the household's head. The routinizability score is an alternative way to look at the effect of technology on jobs and income. A more routinizable job is, ceteris paribus, more likely to be negatively affected by technological progress. An advantage of the routinizability score over our broader technology variable is that it scores every job, be it in manufacturing or services, while the technology variable is set to zero for all jobs in the services sector. A disadvantage of the routinizability score is that it is partly based on perceptions or surveyed households, not actual data.

O Offshorability score. Measures the potential for occupations to be offshored. We use the following O*NET variables to construct it: "face-to-face discussions"; "establishing and maintaining interpersonal relationships"; "assisting and caring for others"; "performing for or working directly with the public"; and "coaching"; "developing others"; "inspecting equipment, structures, or material"; "handling and moving objects"; "controlling machines and processes"; "operating vehicles, mechanized devices, or equipment"; "repairing and maintaining mechanical equipment"; and "repairing and maintaining electronic equipment". Similar to Abdih and Danninger (2017), we aggregate the scores of the above subcomponents to get a composite offshorability score for each occupation. We assign to every household an offshorability score equal to this index for the household's head. The offshorability score is a way to look at the effect of international trade on jobs and income. The more offshorable a job is, ceteris paribus, the more likely it is negatively affected by trade openness progress. A drawback of the offshorability score is that, like the routinizability score, it is partly based on perceptions or surveyed households, not actual data. 
Appendix Table 1 summarizes the sample statistics of the household-level data described above.

\begin{tabular}{|c|c|c|c|c|c|c|}
\hline \multicolumn{7}{|c|}{$\begin{array}{l}\text { Appendix Table 1. Summary Statistics of Household-Level Data } \\
\qquad(1968-2016)\end{array}$} \\
\hline Variables & $\mathrm{HH}$ per year & Mean & Median & Std.Dev. & Min. & Max. \\
\hline Real income / median income (State-Year) & $71,250,000$ & 124.3 & 100.0 & 115.5 & 0.4 & $6,200.8$ \\
\hline Age & $78,333,333$ & 43.3 & 43.0 & 11.4 & 24.0 & 64.0 \\
\hline Gender (male $=1$ ) & $78,333,333$ & 0.7 & 1.0 & 0.5 & 0.0 & 1.0 \\
\hline Education & $76,666,667$ & 13.1 & 13.0 & 3.0 & 0.0 & 21.0 \\
\hline Share of non-white population & $78,333,333$ & 0.2 & 0.0 & 0.4 & 0.0 & 1.0 \\
\hline Age (h. relative) & $58,541,667$ & 37.7 & 38.0 & 15.5 & 0.0 & 99.0 \\
\hline Gender $($ male $=1)(h$. relative $)$ & $58,541,667$ & 0.3 & 0.0 & 0.4 & 0.0 & 1.0 \\
\hline Education (h. relative) & $52,291,667$ & 12.8 & 12.0 & 2.8 & 0.0 & 21.0 \\
\hline Share of non-white population (h. relative) & $78,333,333$ & 0.1 & 0.0 & 0.3 & 0.0 & 1.0 \\
\hline Offshorability score & $61,875,000$ & 31.9 & 31.3 & 4.8 & 15.9 & 47.9 \\
\hline Routinization score & $33,333,333$ & 30.6 & 30.6 & 4.5 & 15.9 & 47.9 \\
\hline Offshorability score (h. relative) & $61,875,000$ & 12.3 & 12.4 & 1.9 & 7.4 & 20.2 \\
\hline Routinization score (h. relative) & $33,333,333$ & 12.40 & 12.56 & 2.03 & 7.37 & 20.18 \\
\hline Manufacturing $(=1)$ & $78,333,333$ & 0.16 & 0.00 & 0.36 & 0.00 & 1.00 \\
\hline Manufacturing $(=1)$ (h. relative) & $58,541,667$ & 0.08 & 0.00 & 0.28 & 0.00 & 1.00 \\
\hline Technology (High tech. $=1)(\mathrm{h}$. head $)$ & $63,541,667$ & 0.02 & 0.00 & 0.14 & 0.00 & 1.00 \\
\hline Technology $($ Medium-high tech. $=1)(\mathrm{h}$. head) & $63,541,667$ & 0.06 & 0.00 & 0.24 & 0.00 & 1.00 \\
\hline Technology (Medium-low tech.=1) $(\mathrm{h}$. head) & $63,541,667$ & 0.03 & 0.00 & 0.17 & 0.00 & 1.00 \\
\hline Technology $($ Low tech. $=1)(h$. head $)$ & $63,541,667$ & 0.08 & 0.00 & 0.27 & 0.00 & 1.00 \\
\hline Technology $($ High tech. $=1)(\mathrm{h}$. relative) & $34,791,667$ & 0.02 & 0.00 & 0.12 & 0.00 & 1.00 \\
\hline Technology (Medium-high tech. $=1$ ) $($ h. relative) & $34,791,667$ & 0.04 & 0.00 & 0.19 & 0.00 & 1.00 \\
\hline Technology (Medium-low tech.=1) (h. relative) & $34,791,667$ & 0.01 & 0.00 & 0.12 & 0.00 & 1.00 \\
\hline Technology $($ Low tech. $=1)(\mathrm{h}$. relative) & $34,791,667$ & 0.07 & 0.00 & 0.26 & 0.00 & 1.00 \\
\hline
\end{tabular}

\section{State-level Data}

This data is for each state at each observation year 1977-2016:

- Real size-adjusted household income. The weighted ${ }^{5}$ income share of low-, middle-, and high-income households.

- Age. The weighted average age of household heads. Similar variable for the second adult in the household.

- Education. The weighted average years of schooling of household heads. Similar variable for the second adult in the household.

- Female share. The weighted share of the household heads with female heads. Similar variable for the second adult in the household.

- Manufacturing. The weighted population share of household heads whose jobs are in manufacturing. Similar variable for the second adult in the household.

- Technology. Measures how high- or low-tech a job is.

\footnotetext{
${ }^{5}$ All weighted-sums and averages in the paper use the CPS population weights.
} 
- Routinization and offshoring levels. The inverse of the weighted average scores for household heads multiplied by 100 . Similar variables for the second adult in the household.

Appendix Table 2 summarizes the sample statistics of the state-level data described above and Appendix Figures 1A and 1B show the ranges of the time series of all the independent variables in the state-level regressions.

\begin{tabular}{|c|c|c|c|c|c|c|}
\hline \multicolumn{7}{|c|}{$\begin{array}{l}\text { Appendix Table 2. Summary Statistics of State-Level Data } \\
\qquad(1977-2016)\end{array}$} \\
\hline Variables & Obs & Mean & Median & Std.Dev. & Min. & Max. \\
\hline Index Hollowing-out (downward) & 2,040 & 116.0 & 116.5 & 12.8 & 78.7 & 156.1 \\
\hline Index Hollowing-out (upward) & 2,040 & 129.4 & 134.2 & 30.3 & 34.0 & 217.0 \\
\hline Population share index (downward) & 2,040 & 117.6 & 118.0 & 16.1 & 62.2 & 174.9 \\
\hline Population share index (upward) & 2,040 & 107.6 & 107.3 & 10.3 & 75.1 & 147.8 \\
\hline Age & 2,040 & 43.0 & 42.9 & 1.5 & 37.5 & 47.4 \\
\hline Education & 2,040 & 13.4 & 13.6 & 0.7 & 10.8 & 15.9 \\
\hline Share of non-white population & 2,040 & 15.8 & 12.9 & 13.2 & 0.1 & 73.7 \\
\hline Share of females (h. head) & 2,040 & 35.5 & 36.3 & 11.3 & 9.8 & 60.8 \\
\hline Share of single females with children (h. head) & 2,040 & 11.0 & 10.9 & 2.5 & 3.1 & 21.6 \\
\hline Offshoring & 2,040 & 3.2 & 3.2 & 0.1 & 2.9 & 3.6 \\
\hline Routinization & 2,040 & 8.3 & 8.3 & 0.2 & 7.8 & 9.0 \\
\hline Share of manufacturing employees & 2,040 & 14.6 & 13.4 & 7.5 & 1.1 & 38.7 \\
\hline Share of high tech. sector employees & 2,040 & 1.6 & 1.2 & 1.4 & 0.0 & 10.3 \\
\hline Share of medium-high tech. sector employees & 2,040 & 4.5 & 3.8 & 3.5 & 0.0 & 23.1 \\
\hline Share of medium-low tech. sector employees & 2,040 & 2.0 & 1.7 & 1.6 & 0.0 & 10.8 \\
\hline Share of low tech. sector employees & 2,040 & 6.5 & 5.8 & 3.6 & 0.6 & 21.9 \\
\hline
\end{tabular}




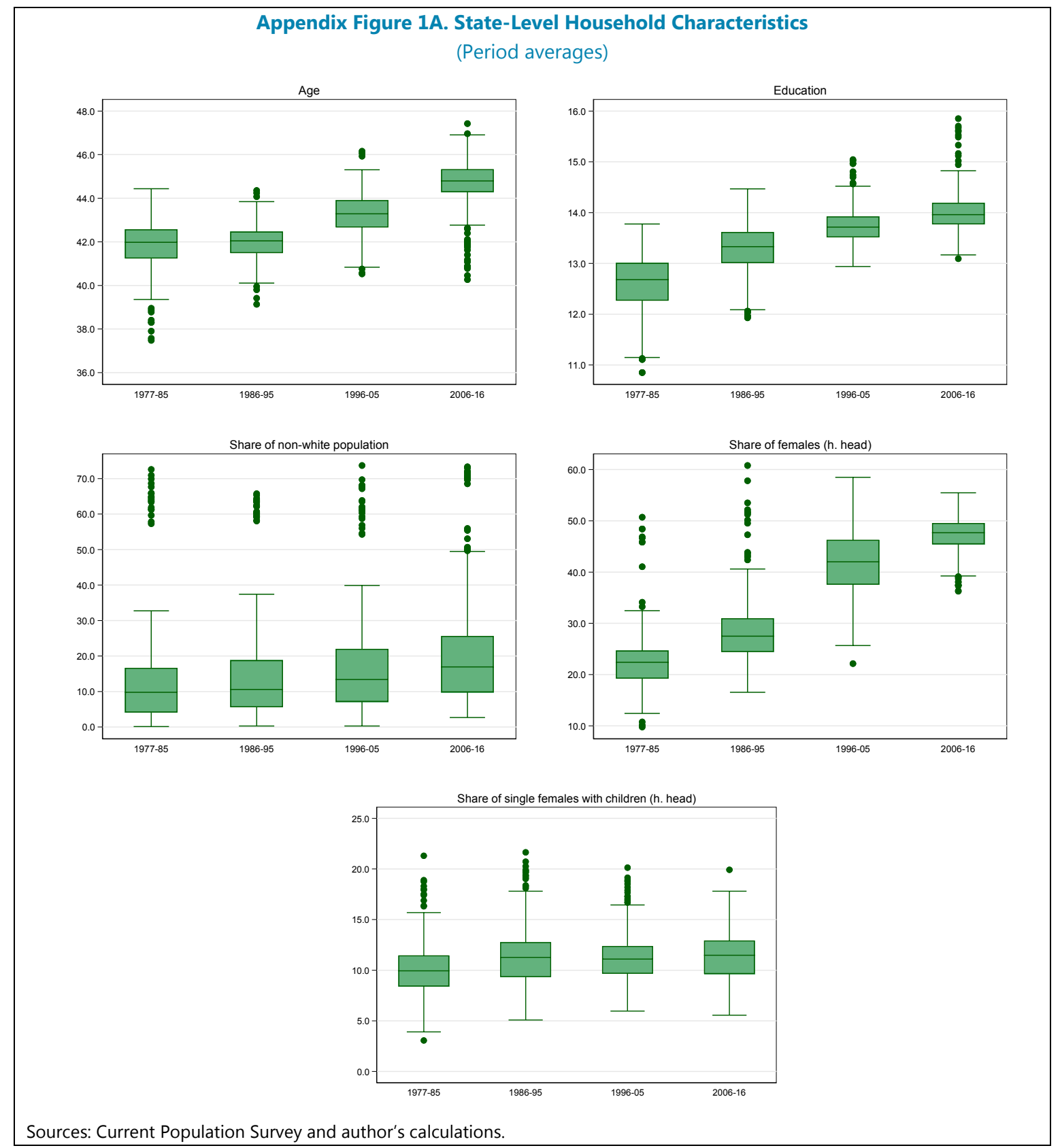




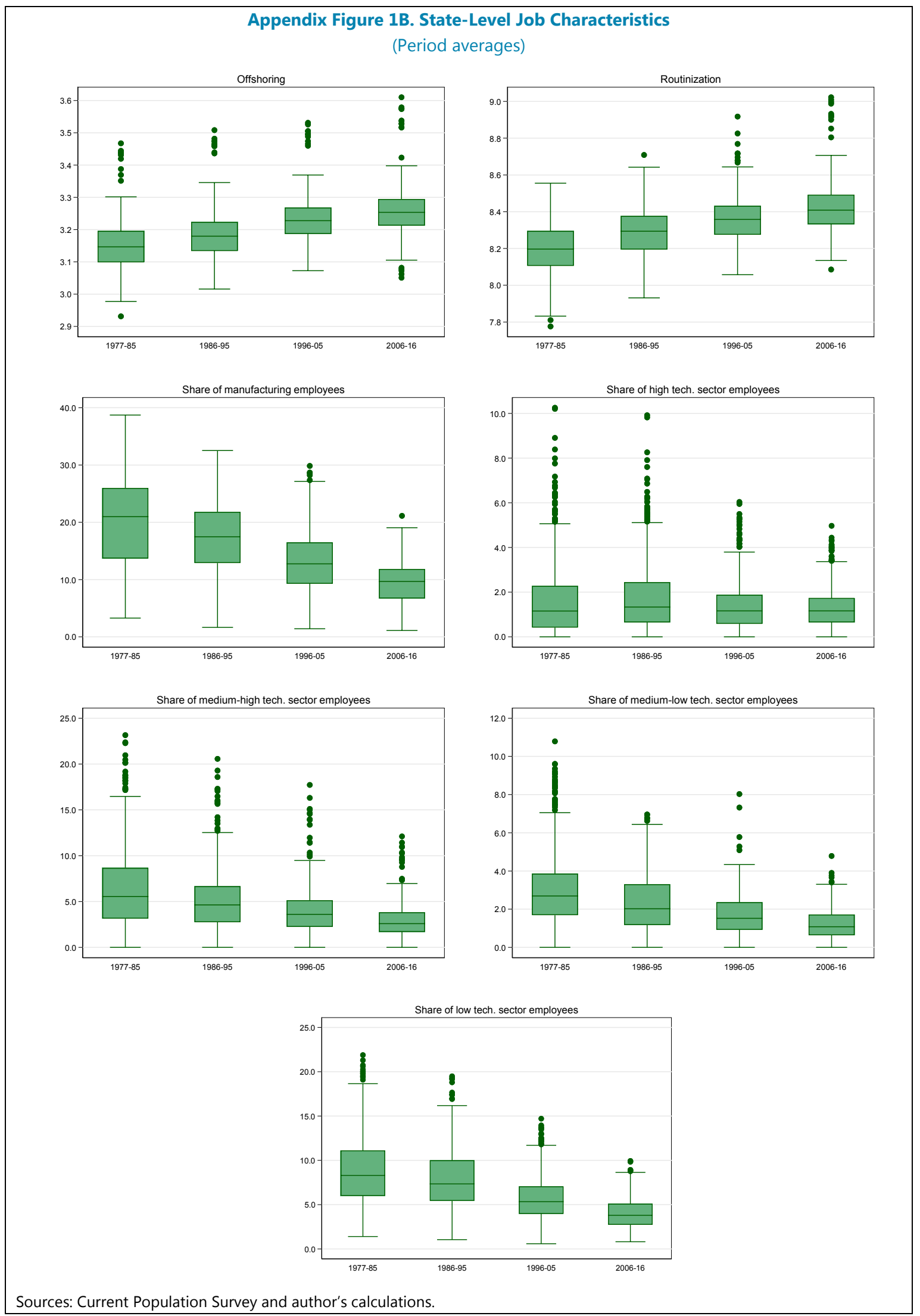




\section{Overview of the CPS ${ }^{6}$}

The CPS data is monthly at the national. Its sampling unit is all individuals in a dwelling, which is called a household. The CPS dates back to 1962 and samples about 50,000 households monthly. We use the CPS from 1968 to 2016. The CPS rotates households out of the survey for 8 months after 4 months in the survey and finally rotates them out of the survey after 4 more months in the survey. The CPS March Supplement (Annual Social and Economic Supplement) includes detailed income questions about the previous year from which annual income for the previous year is constructed. We do not exploit this short panel dimension for our econometric estimation, but future work could do so.

In the CPS, variables are labeled with their survey's publication year, rather than their survey year. For example, data labeled with 2017, were the results of the survey that was conducted in 2016, but published in 2017. Therefore, throughout our paper, we have lagged the data and have presented the data of each year labeled by the same year. For example, throughout this paper, data of 2016 refers to the data that was produced with the survey that asked about household information for 2016 and published in 2017.

\section{Sampling Unit}

The CPS aims to be nationally and state-wide representative of all civilian, non-institutionalized individuals, so a housing unit or dwelling serves as the sampling unit. Formally, the U.S. Census Bureau states that for the CPS "[a] household consists of all people who occupy a housing unit regardless of relationship." We document income polarization on the family unit (FU) level. For the CPS "[a] family consists of two or more people related by birth, marriage, or adoption residing in the same housing unit."

In describing the sample that we use, our main reference is the head of household. The CPS interviews a "reference person" and defines all other relationships based on this person (see variable "RELATE"). In the regression analysis, we also include variables related to the second adult in the household.

\section{Income}

For the CPS, we use the variable "FTOTVAL" which is reported total family income and includes transfers. ${ }^{7}$ Prior to 1976, this variable is top-coded at 50,000 dollars. However this censoring affects less than 0.5 percent of observations each year in our sample. Consequently, we do not correct for top-coding. However, this only affects our descriptive analysis at the national level because our state-level data start in 1977. The CPS also imputes missing values for income. ${ }^{8}$ We do not drop imputed values as they are widely used. Dropping them significantly reduces the sample size and makes use of the weights problematic as pointed out by Heathcote, Perri, and Violante (2010). Family income consists of taxable income for the head of household and the second adult in the households and transfers to them. Taxable income is the sum of labor

\footnotetext{
${ }^{6}$ Heathcote et al (2010) provide an extensive summary of these datasets and their structure.

${ }^{7}$ The CPS March income questions changed in 1975 and 1987, but Heathcote, Perri and Violante (2010) find that these changes do not notably impact total income.

${ }^{8}$ We are not aware of a systematic study that evaluates the impact of imputing missing values in the CPS, so we cannot say how it influences the trends we observe.
} 
income (wages and salaries, bonuses, tips, etc.), asset income (rental income, farm income, unincorporated business income, dividends, and interest), and taxable pension income (annuities and IRAs, pensions, other retirement accounts). Transfers include alimony, child support, social security, worker's compensation and VA pensions.

The CPS provides no information on asset holdings aside from indicating home ownership. This is one reason we have limited our study to income polarization and have noted ventured into wealth polarization.

\section{Sample Restrictions}

We impose some restrictions on our sample to access trends. For each survey, we take only observations where 1) information for the head of household (i.e. income, age) is available, 2) the head of household is aged 24 to 64 and 3) the head of household resides in the U.S. The latter restriction serves to make the sample representative of working U.S. families. We also drop extremely poor families as defined by less than 2 dollars per day in real 2005 terms. 


\section{Appendix II. Income Polarization by State}
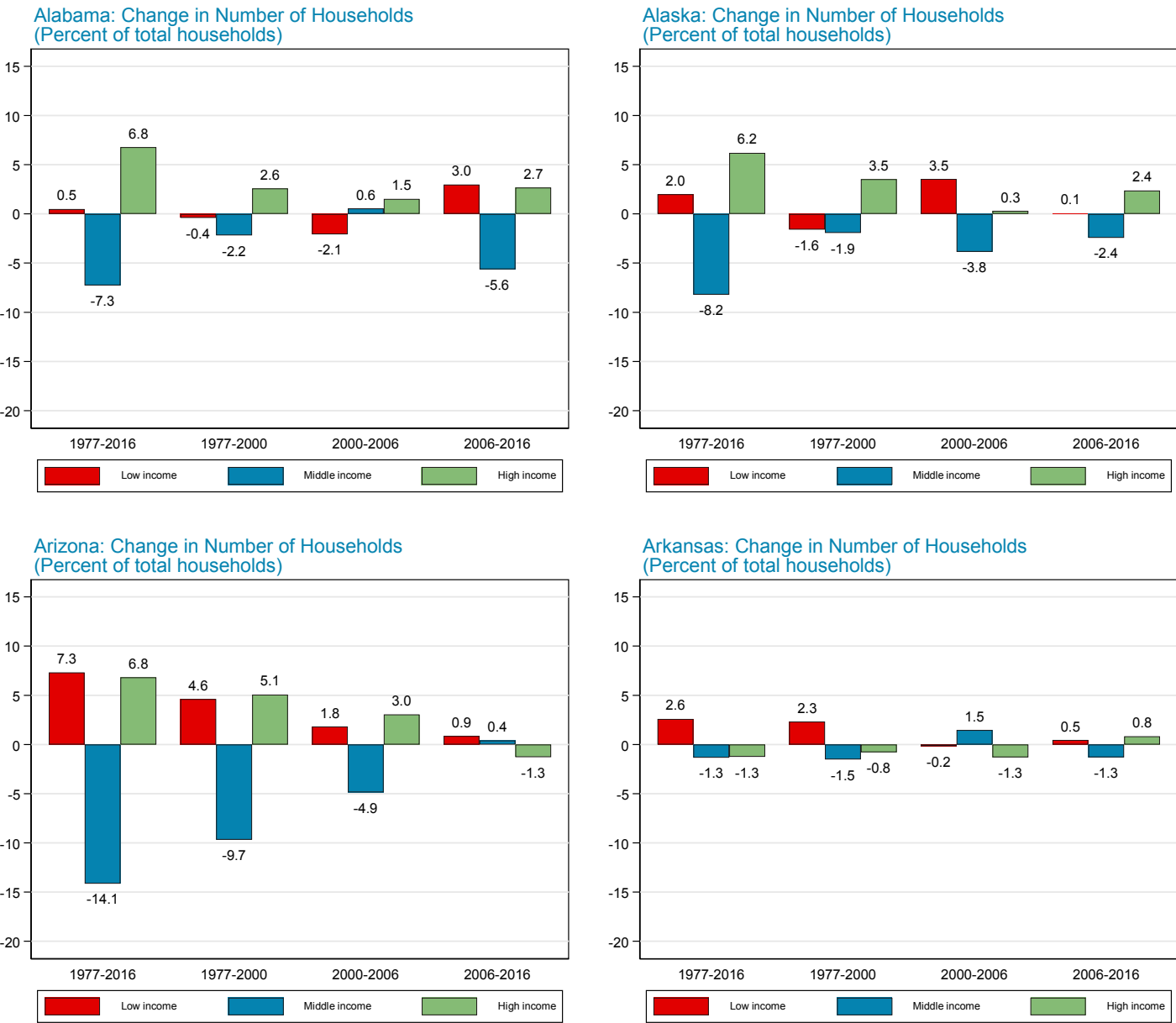

Arkansas: Change in Number of Households (Percent of total households)

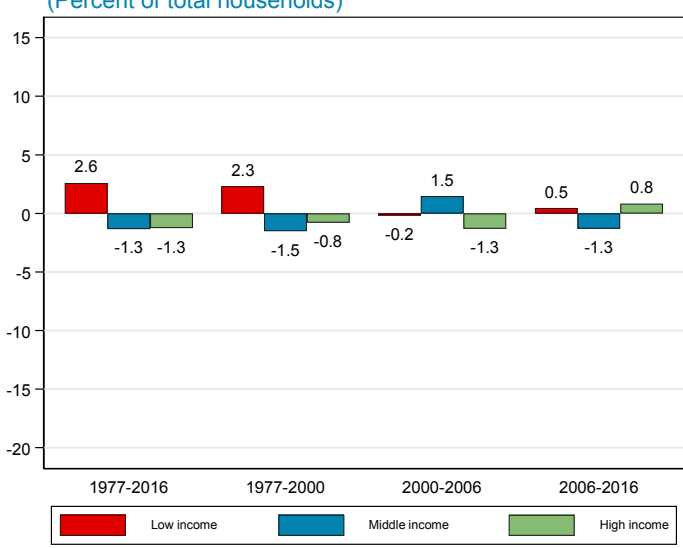

California: Change in Number of Households (Percent of total households)

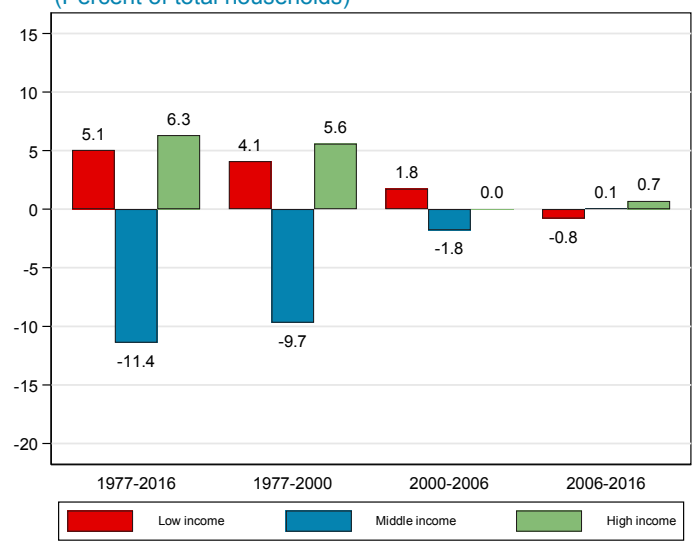

Colorado: Change in Number of Households (Percent of total households)

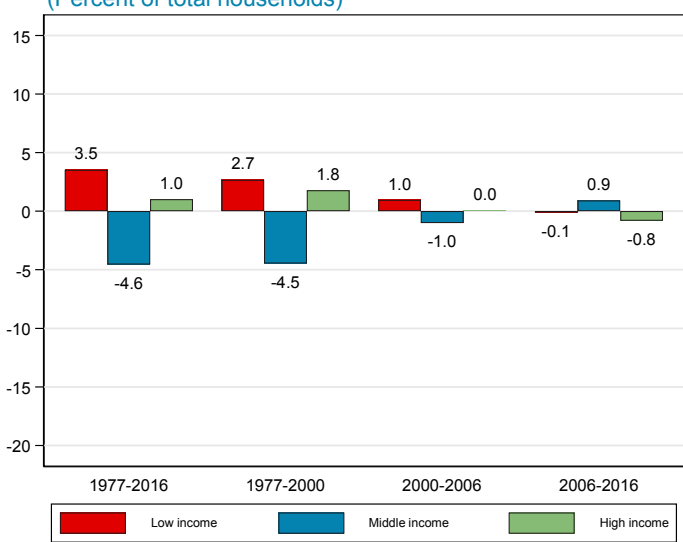

${ }^{1}$ Charts are compiled using CPS data. Income is adjusted for household size using OECD's equivalence scale. Middle income (class) consists of households falling within 50-150 percent of median income. 

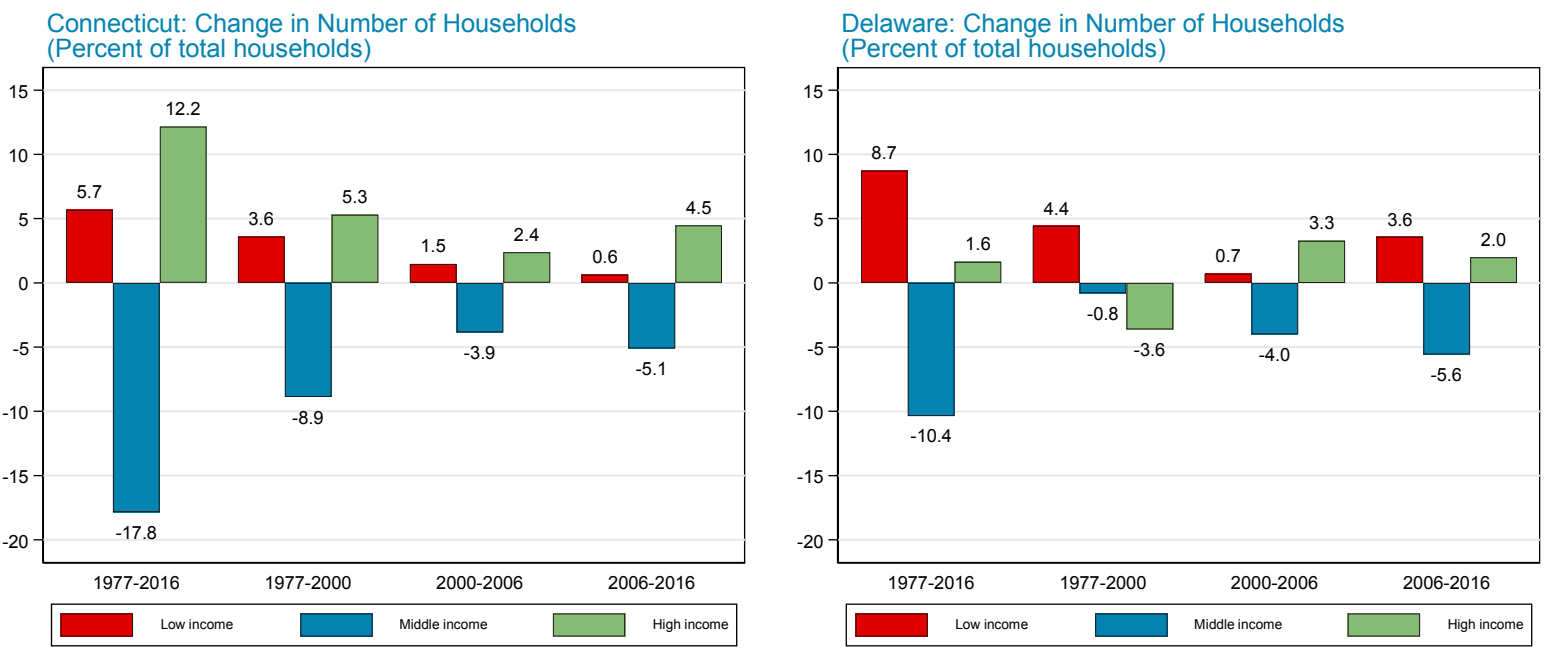

District of Columbia: Change in Number of Households (Percent of total households)

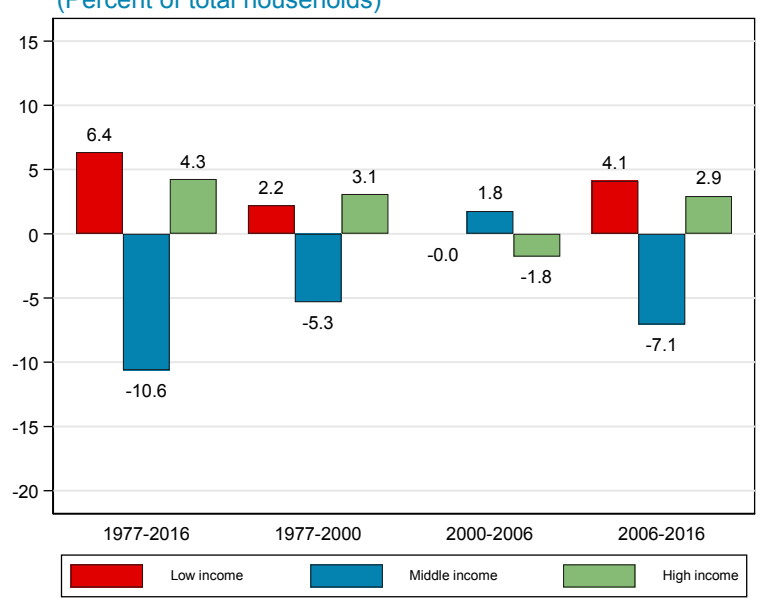

Florida: Change in Number of Households (Percent of total households)

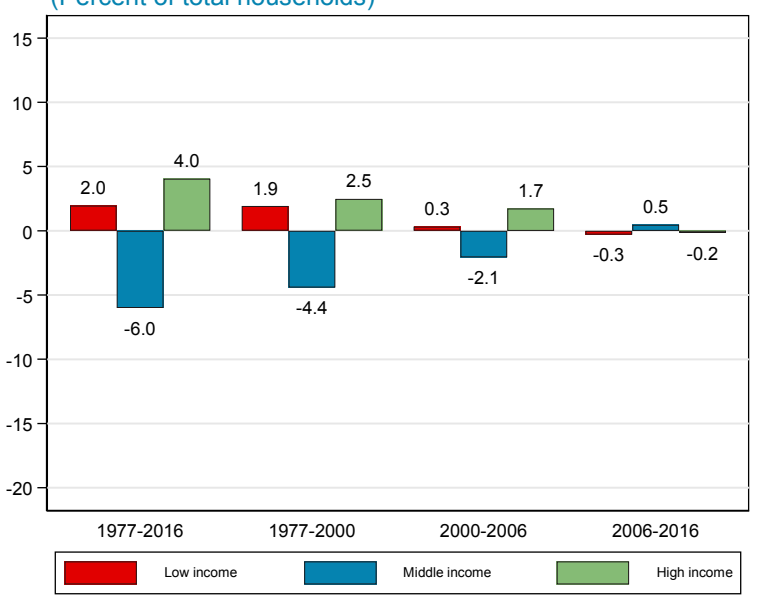

Georgia: Change in Number of Households (Percent of total households)

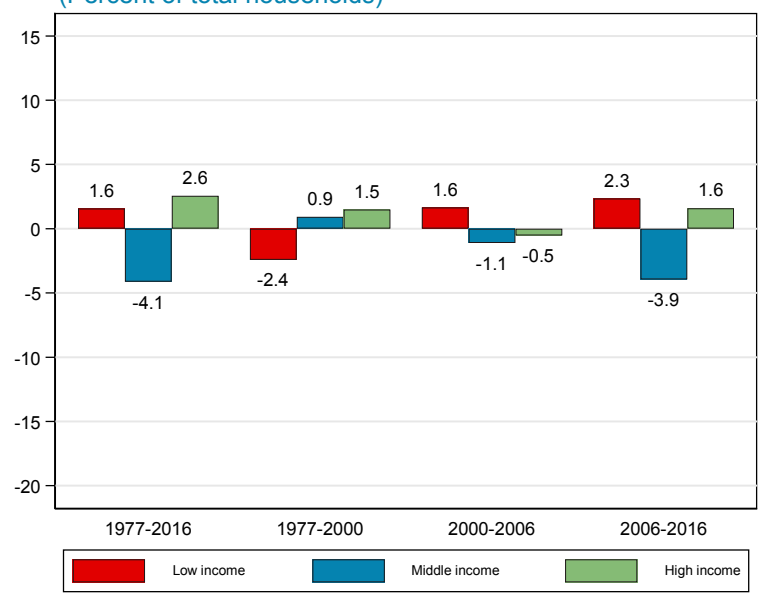

Hawaii: Change in Number of Households (Percent of total households)

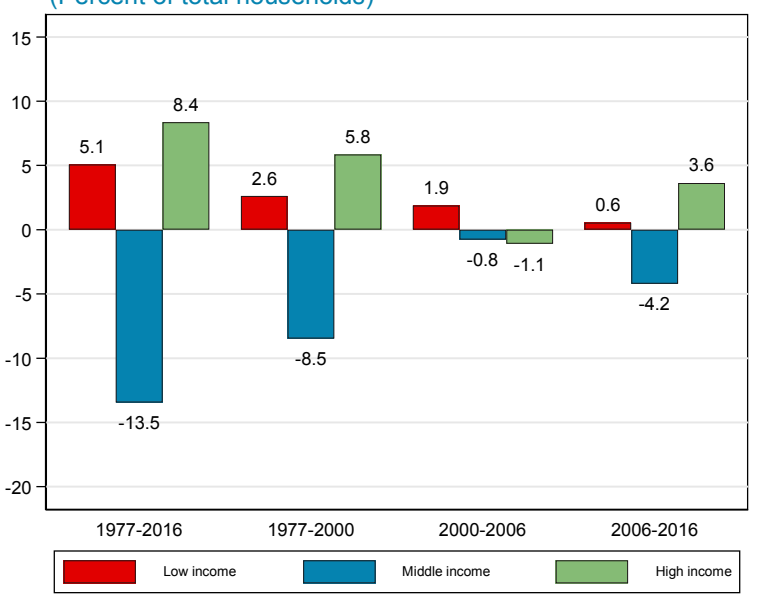



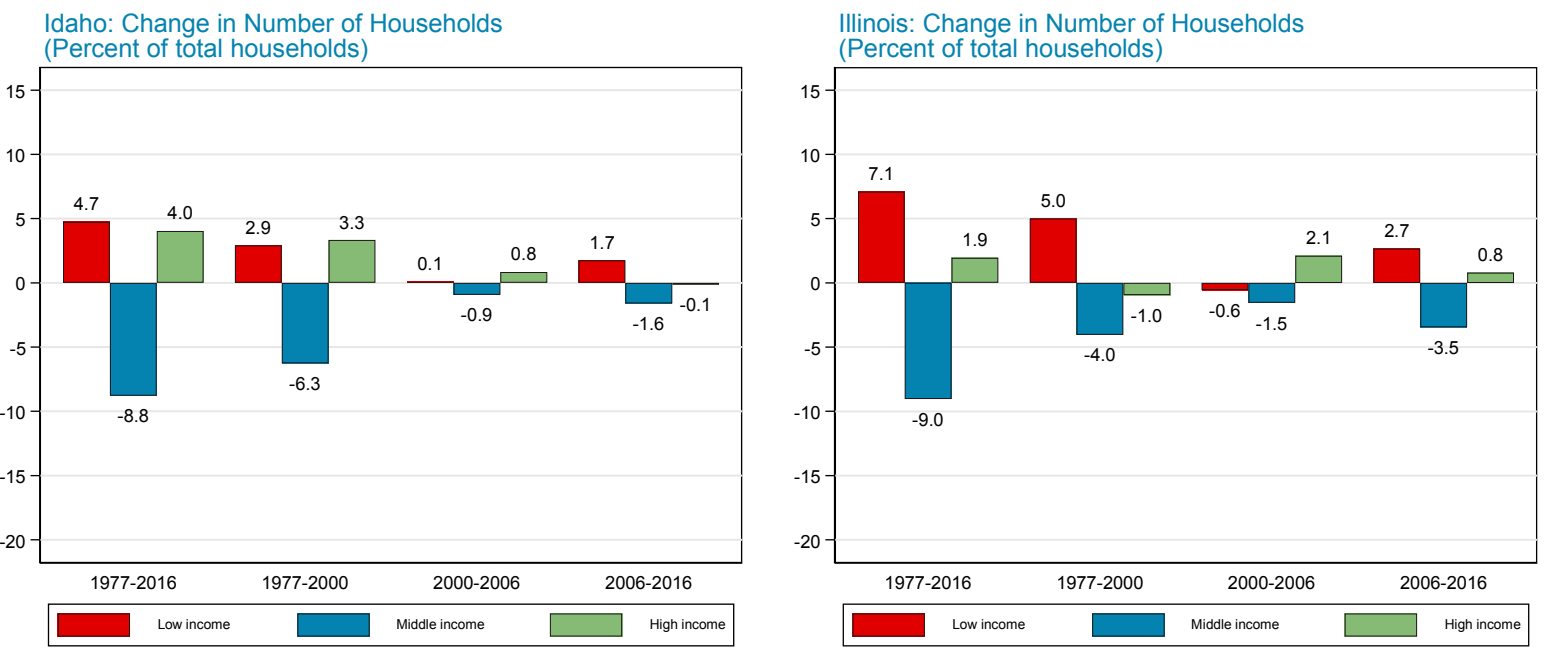

Indiana: Change in Number of Households (Percent of total households)

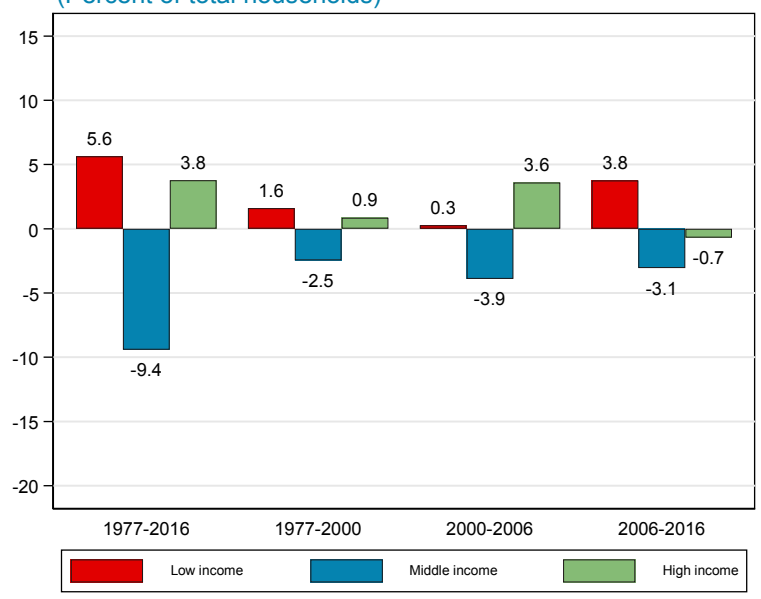

lowa: Change in Number of Households (Percent of total households)

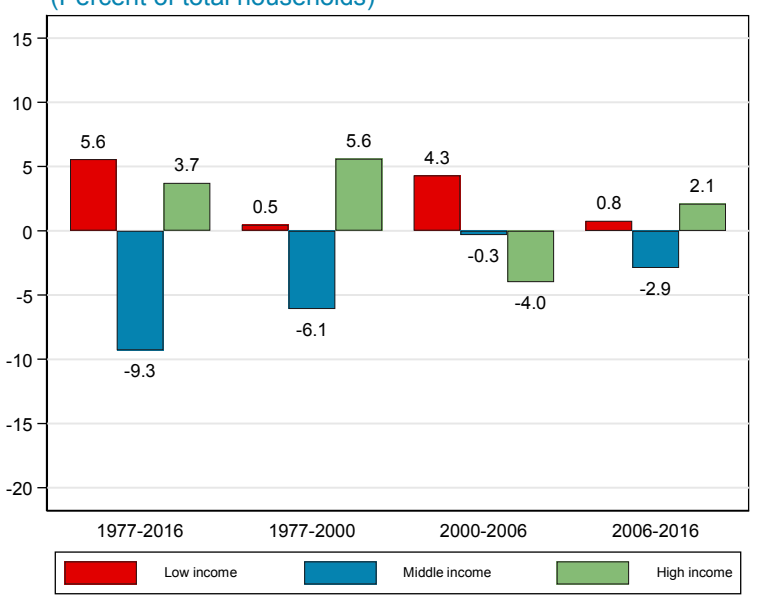

Kansas: Change in Number of Households (Percent of total households)

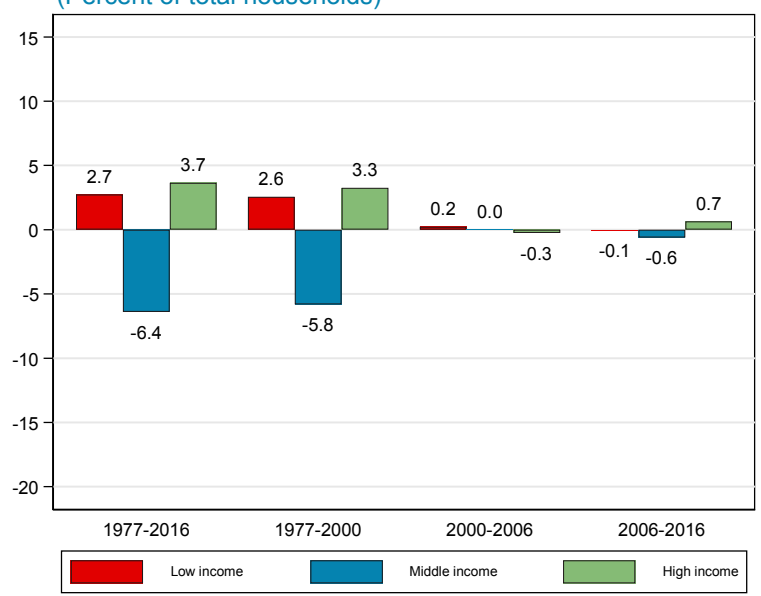

Kentucky: Change in Number of Households (Percent of total households)

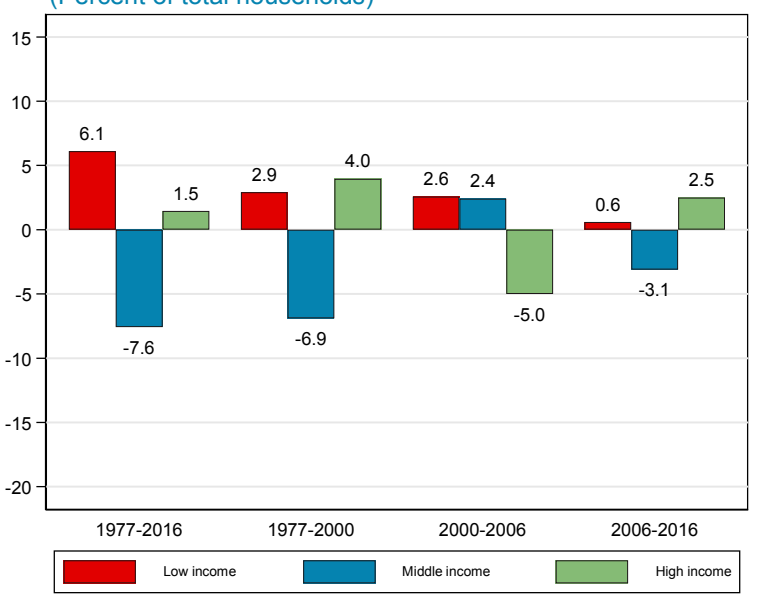



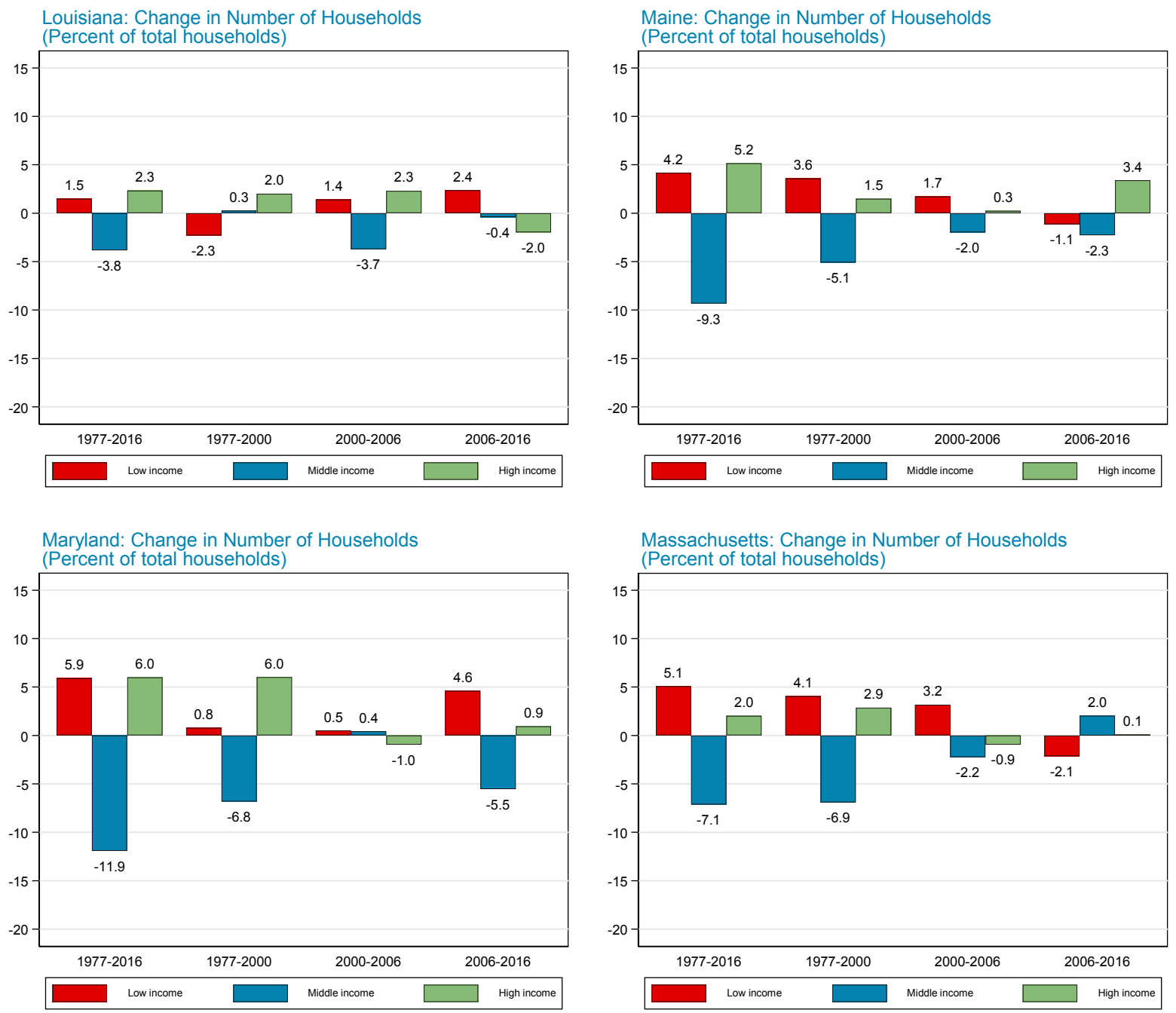

Michigan: Change in Number of Households (Percent of total households)

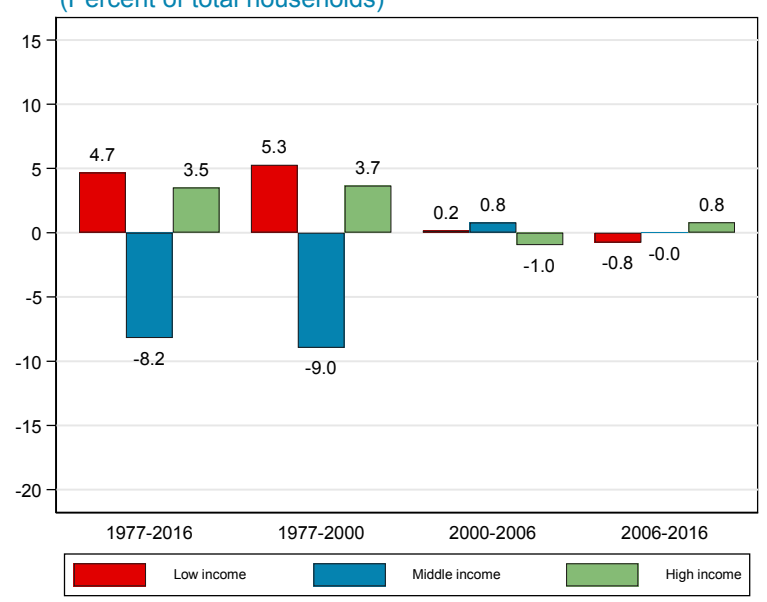

Minnesota: Change in Number of Households (Percent of total households)

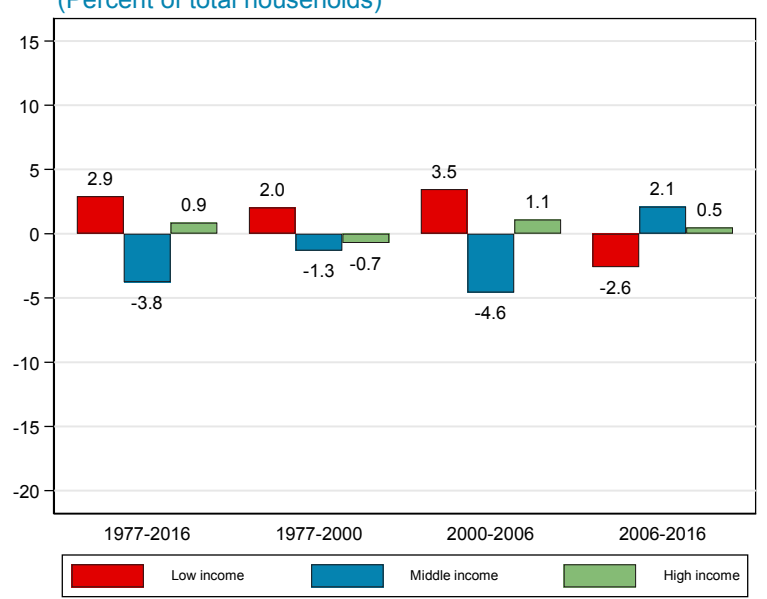



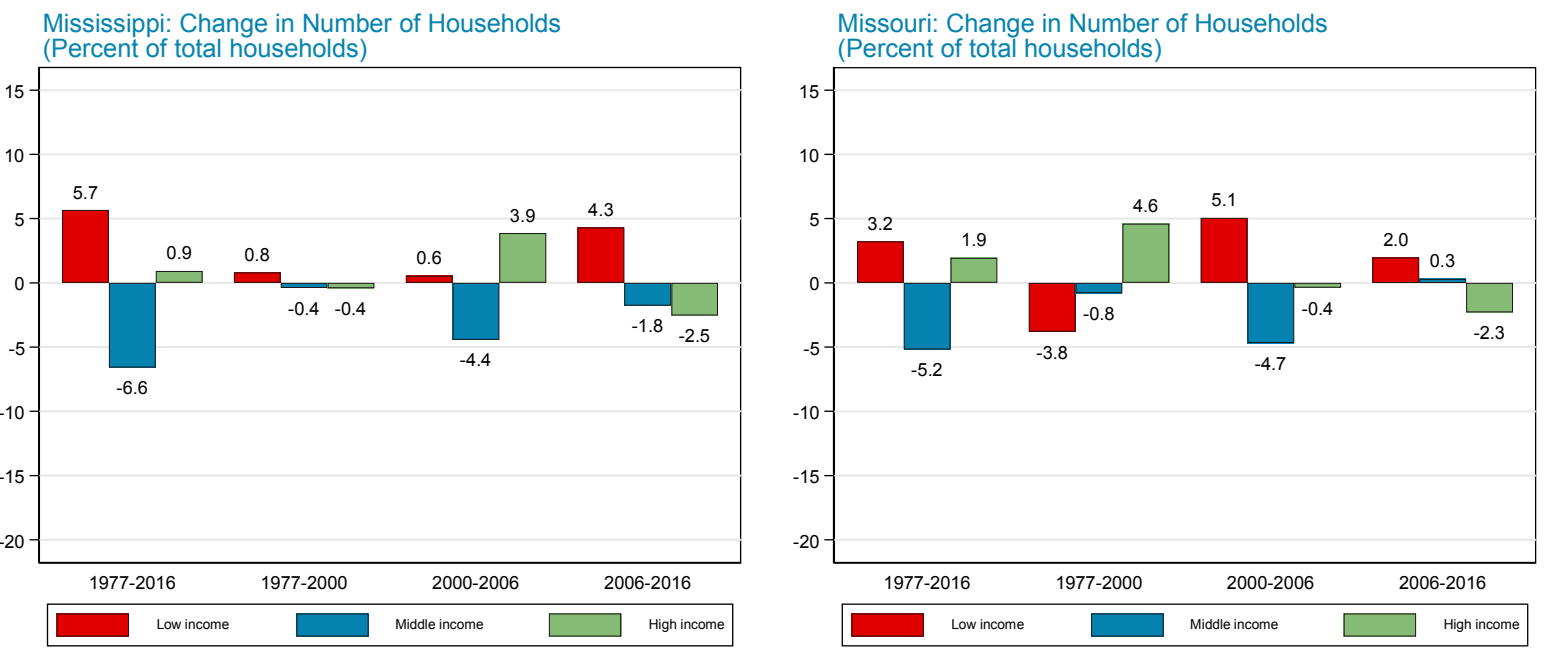

Montana: Change in Number of Households (Percent of total households)

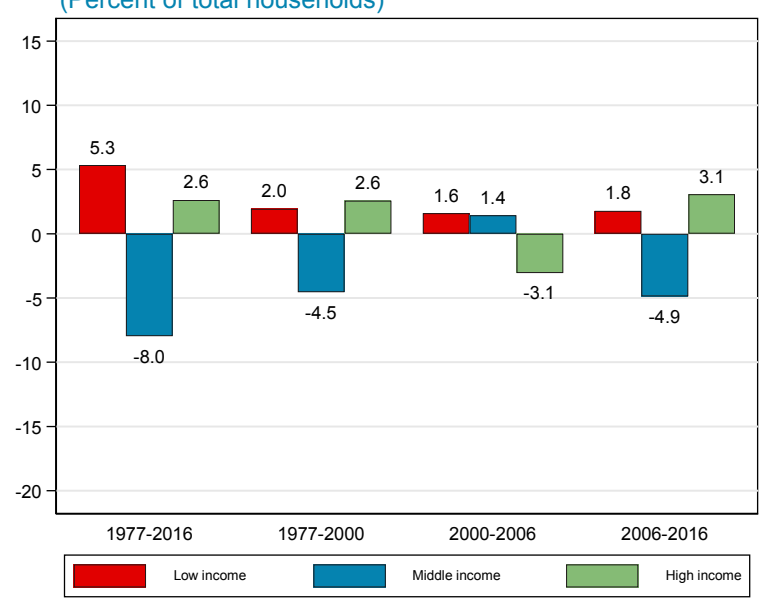

Nebraska: Change in Number of Households (Percent of total households)

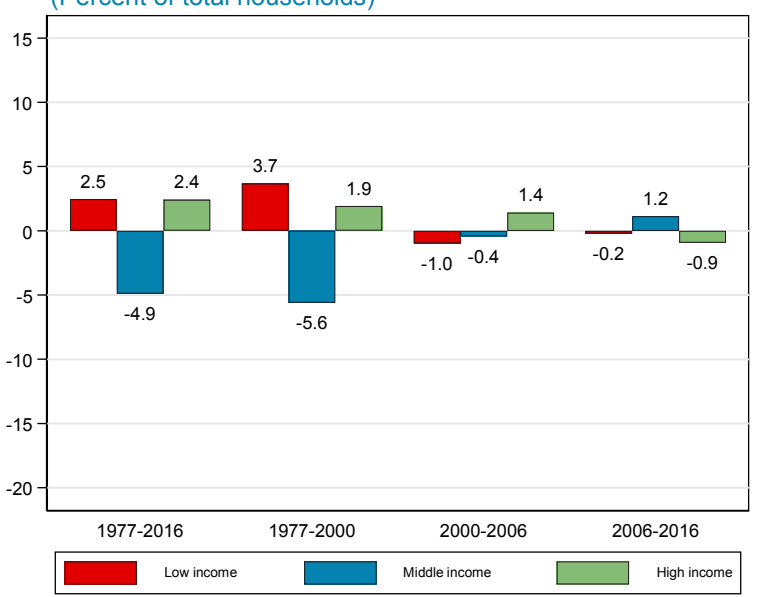

Nevada: Change in Number of Households (Percent of total households)

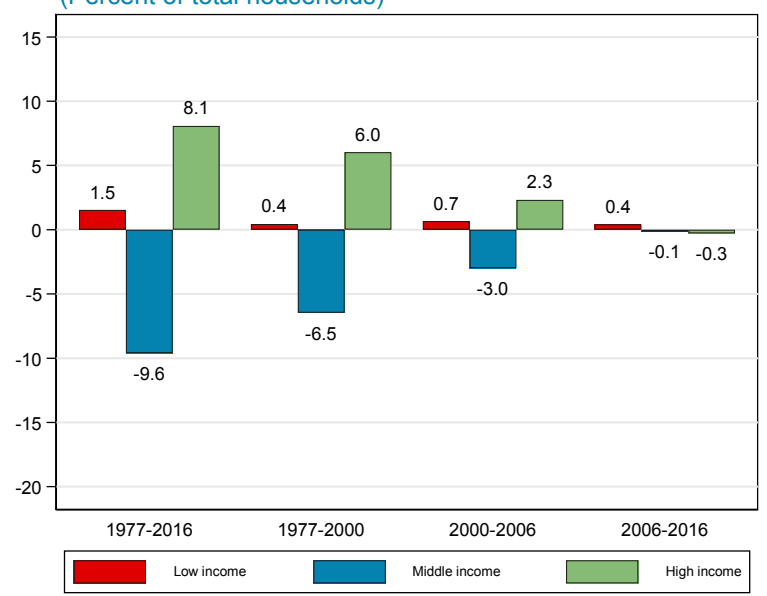

New Hampshire: Change in Number of Households (Percent of total households)

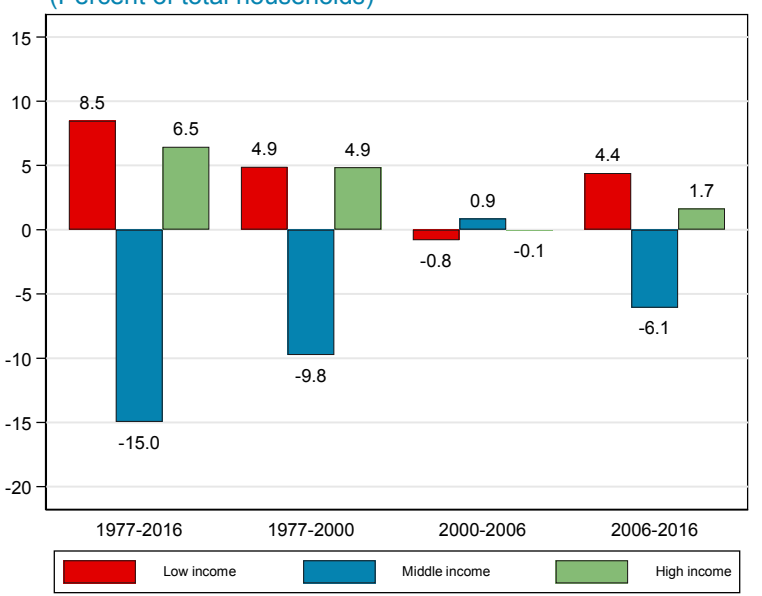



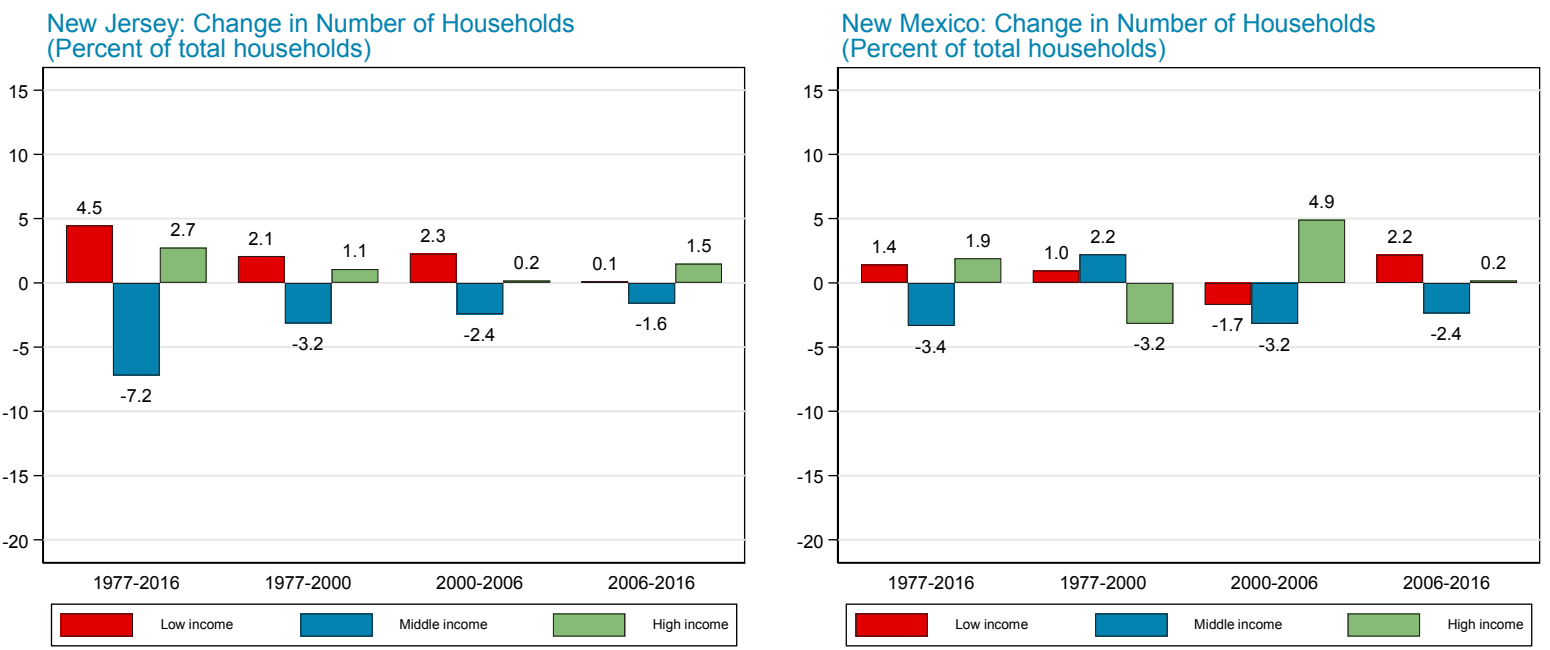

New York: Change in Number of Households (Percent of total households)

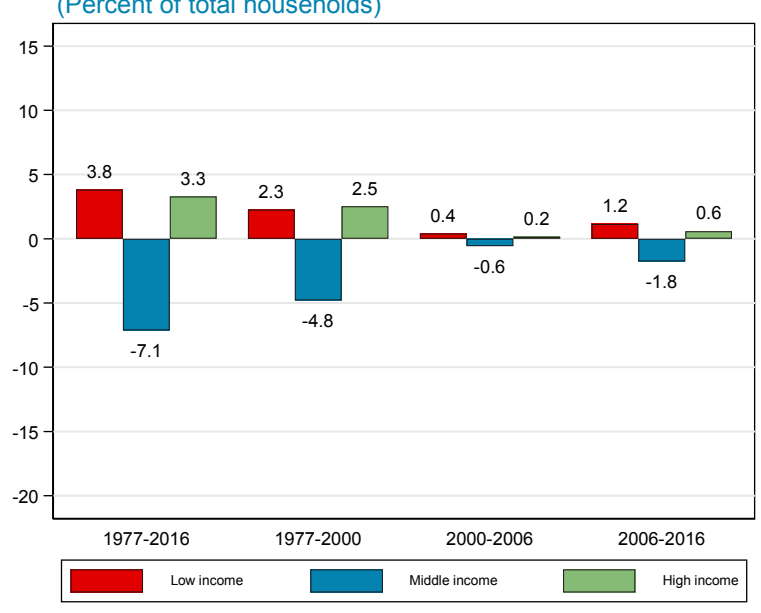

North Carolina: Change in Number of Households (Percent of total households)

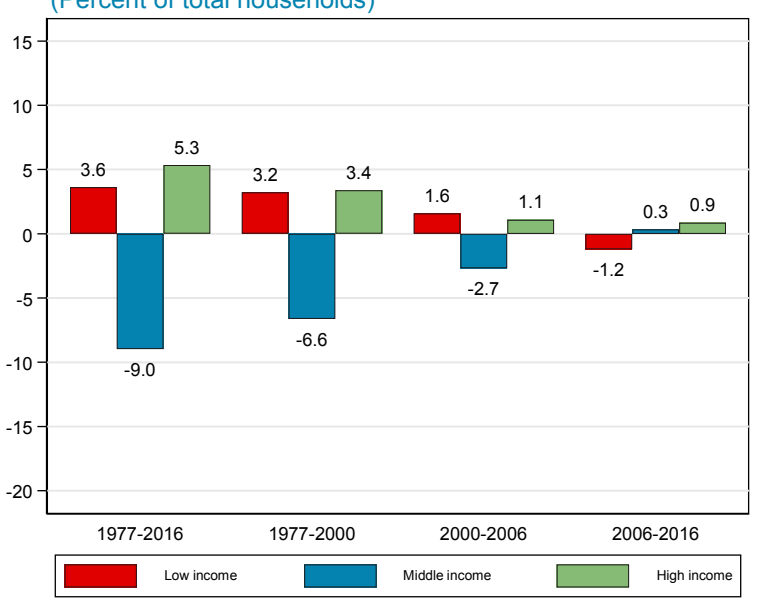

North Dakota: Change in Number of Households (Percent of total households)

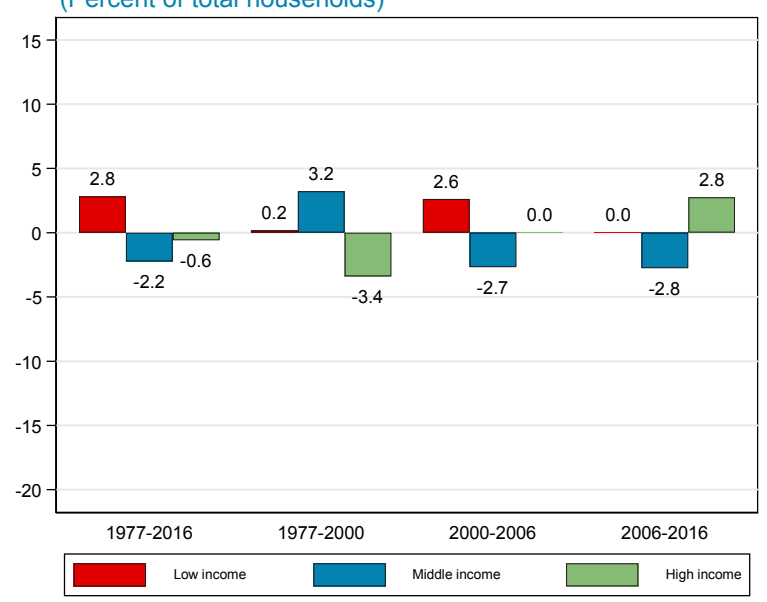

Ohio: Change in Number of Households (Percent of total households)

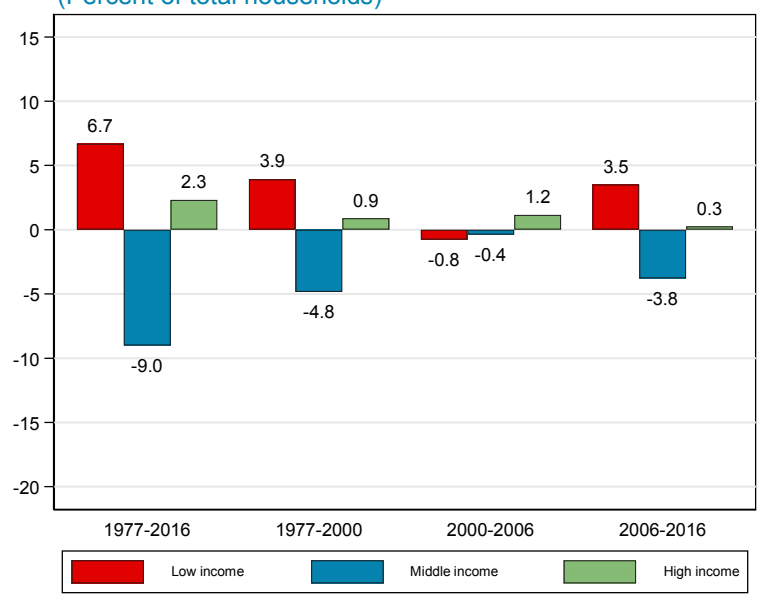


Oklahoma: Change in Number of Households (Percent of total households)

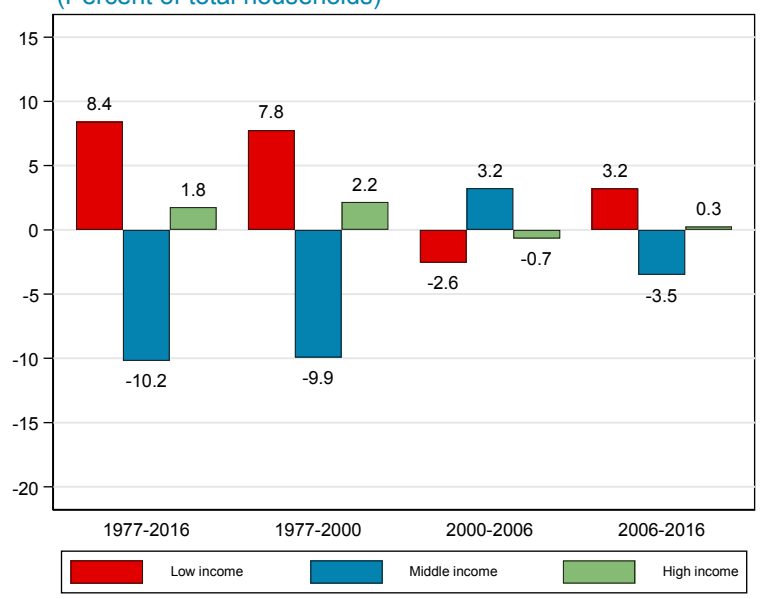

Pennsylvania: Change in Number of Households (Percent of total households)

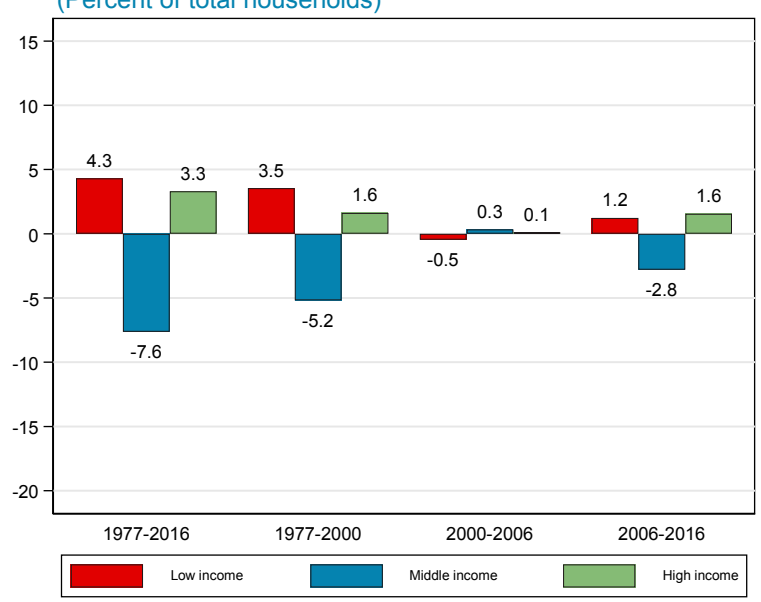

South Carolina: Change in Number of Households (Percent of total households)

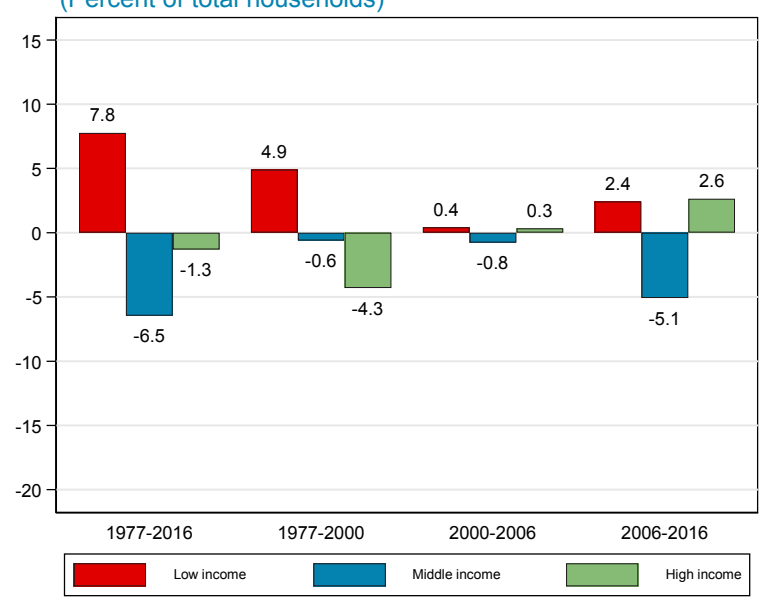

Oregon: Change in Number of Households (Percent of total households)

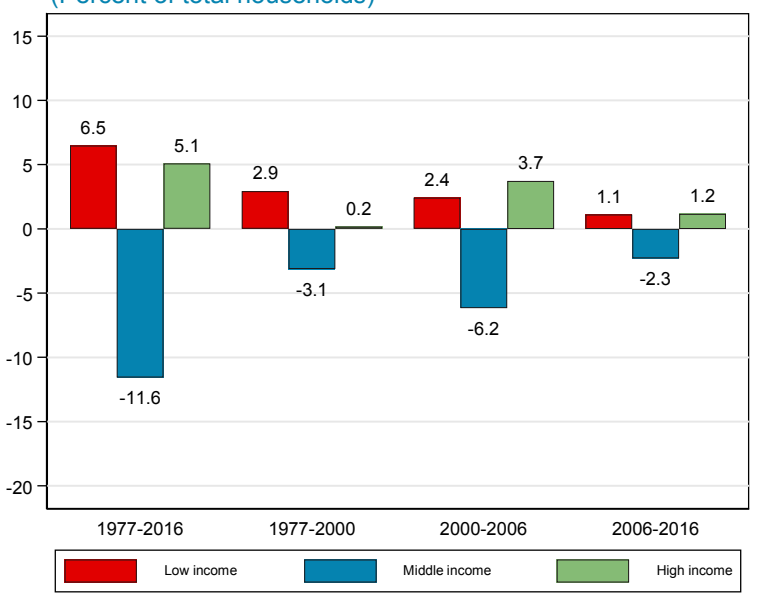

Rhode Island: Change in Number of Households (Percent of total households)

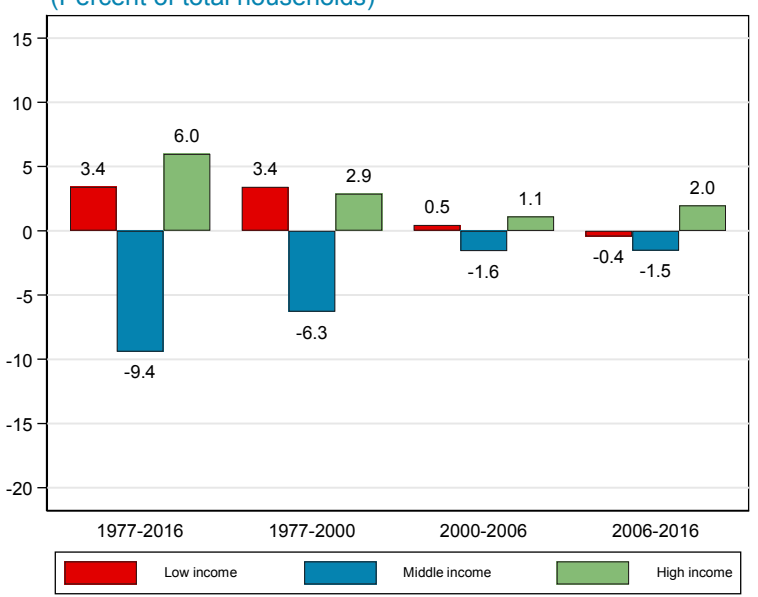

South Dakota: Change in Number of Households (Percent of total households)

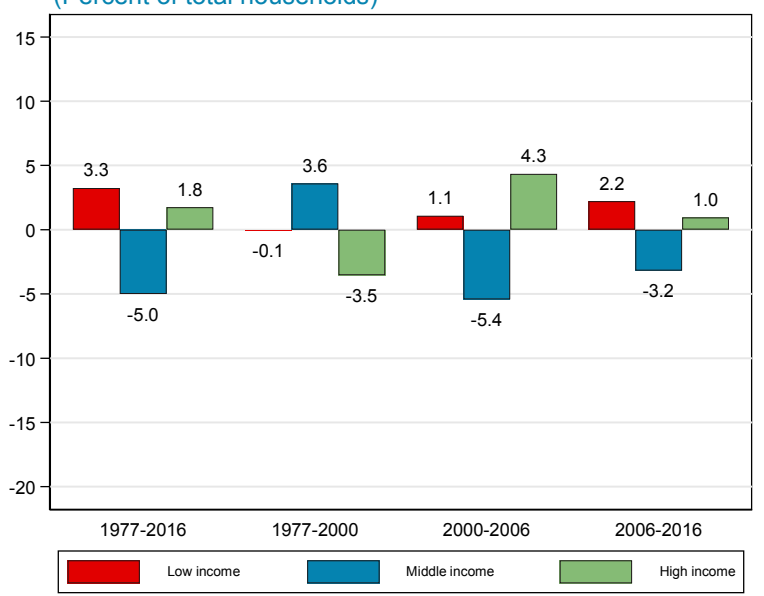



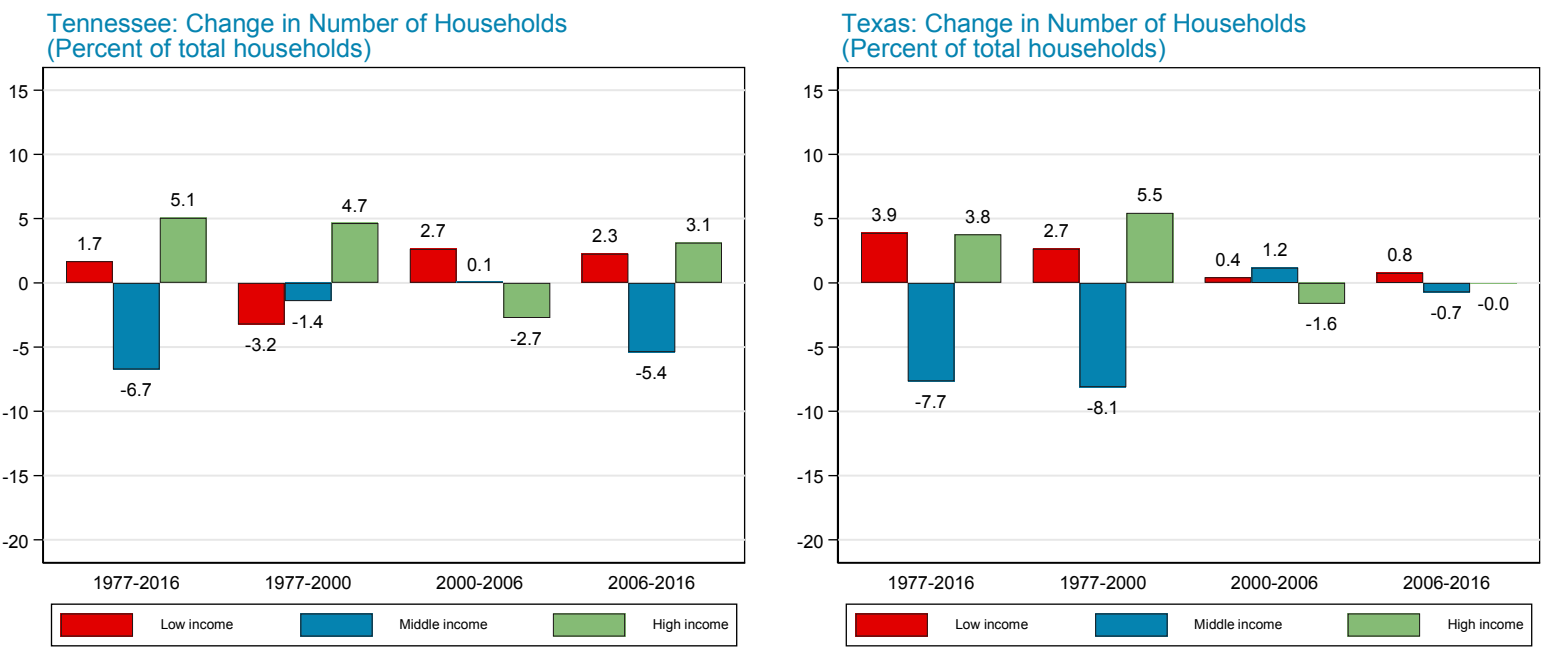

Utah: Change in Number of Households

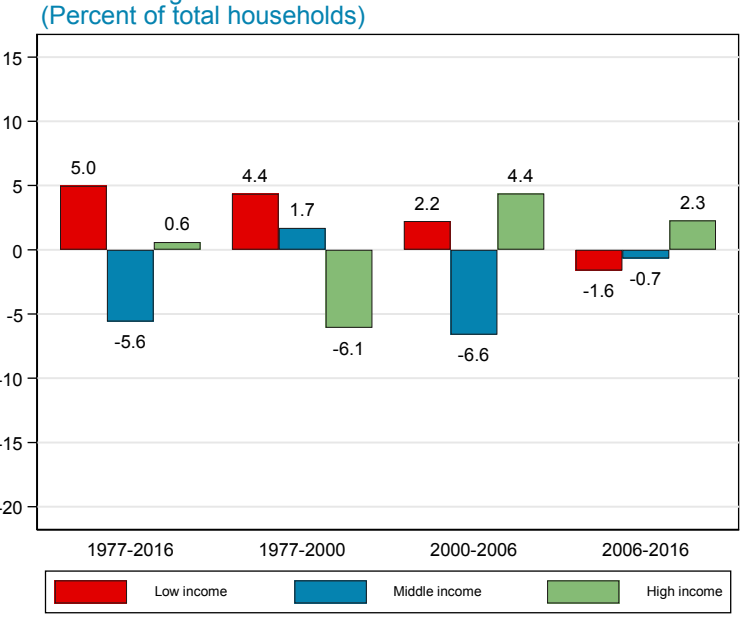

Vermont: Change in Number of Households (Percent of total households)

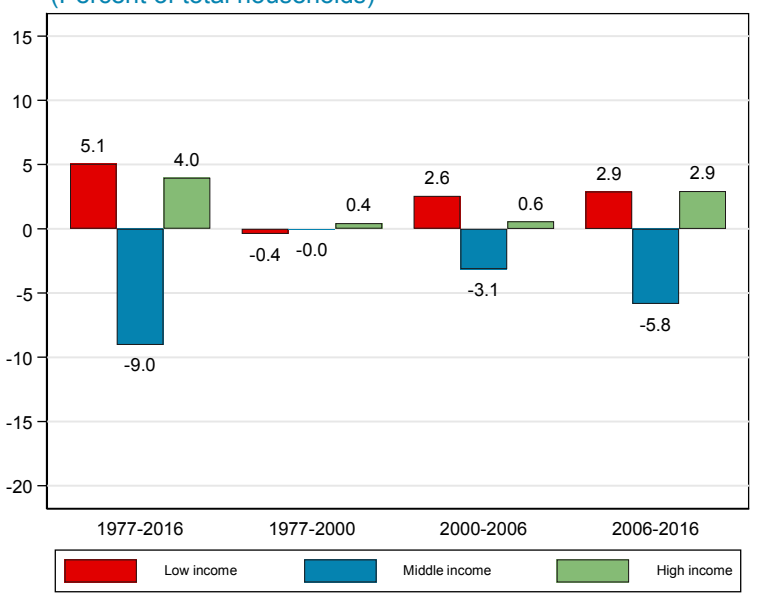

Virginia: Change in Number of Households

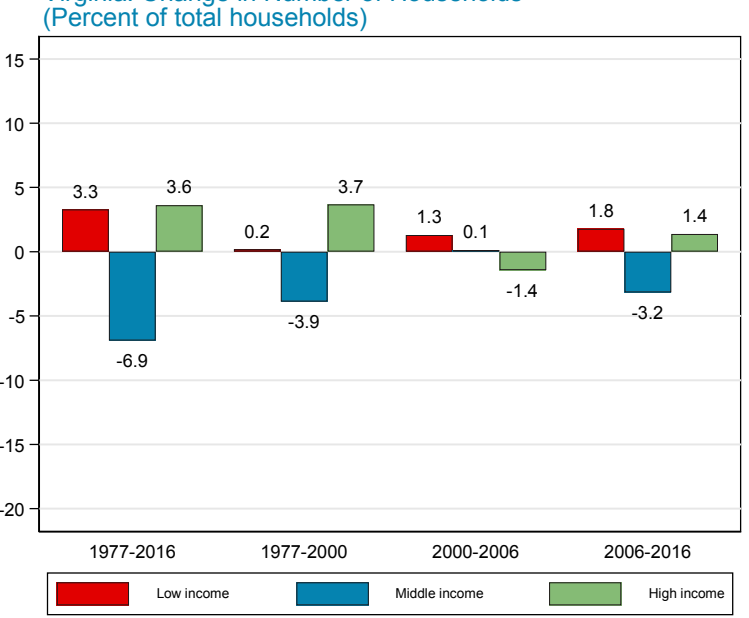

Washington: Change in Number of Households (Percent of total households)

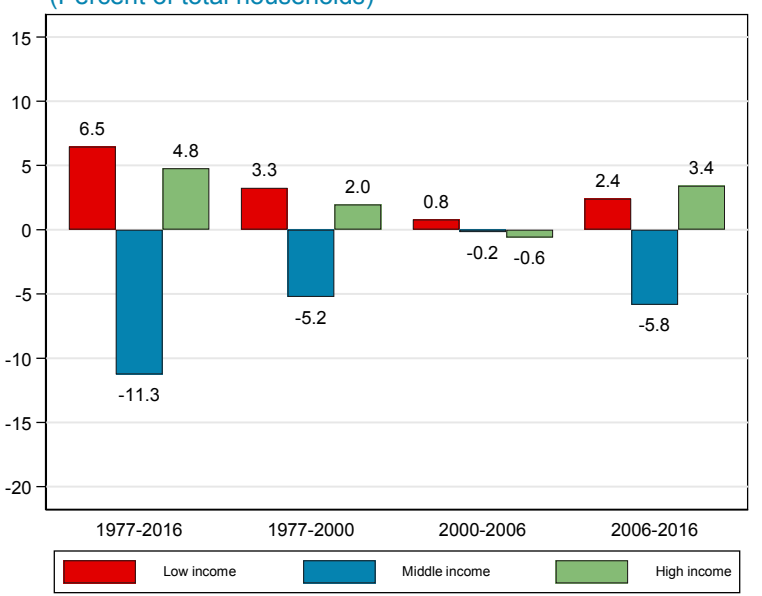



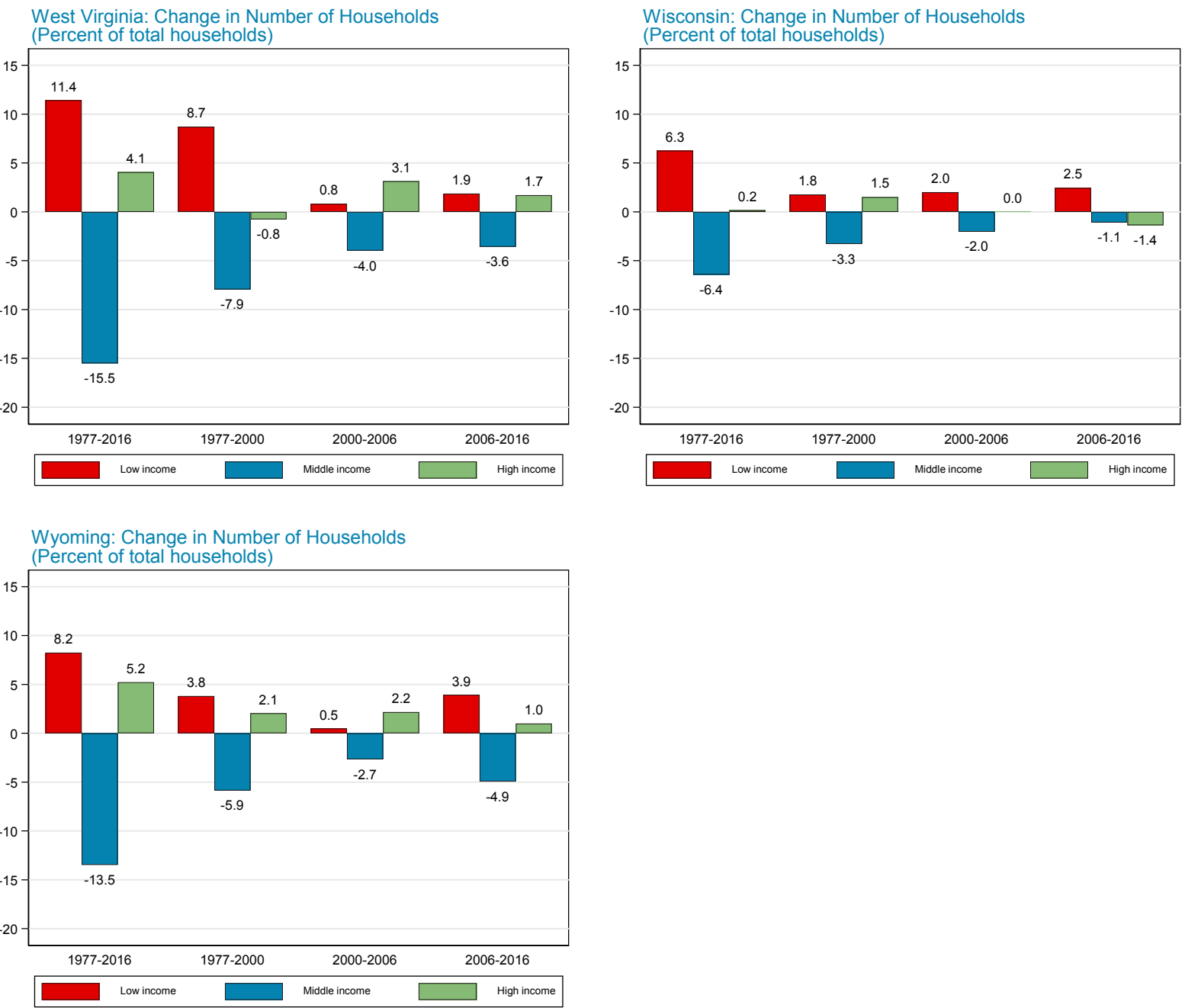

Sources: Current Population Survey and author's calculations. 


\section{Appendix III. Wolfson's Index of Income Polarization}

Wolfson constructs this index ${ }^{1}$ from the area under what he calls the "polarization curve," which is a rotation and rescaling of the Lorenz curve by median income. This area is between the Lorenz curve and a tangent line at the $50^{\text {th }}$ percentile of the population as shown in Appendix Figure 2.

Appendix Figure 2. Polarization Index and Gini Coefficent

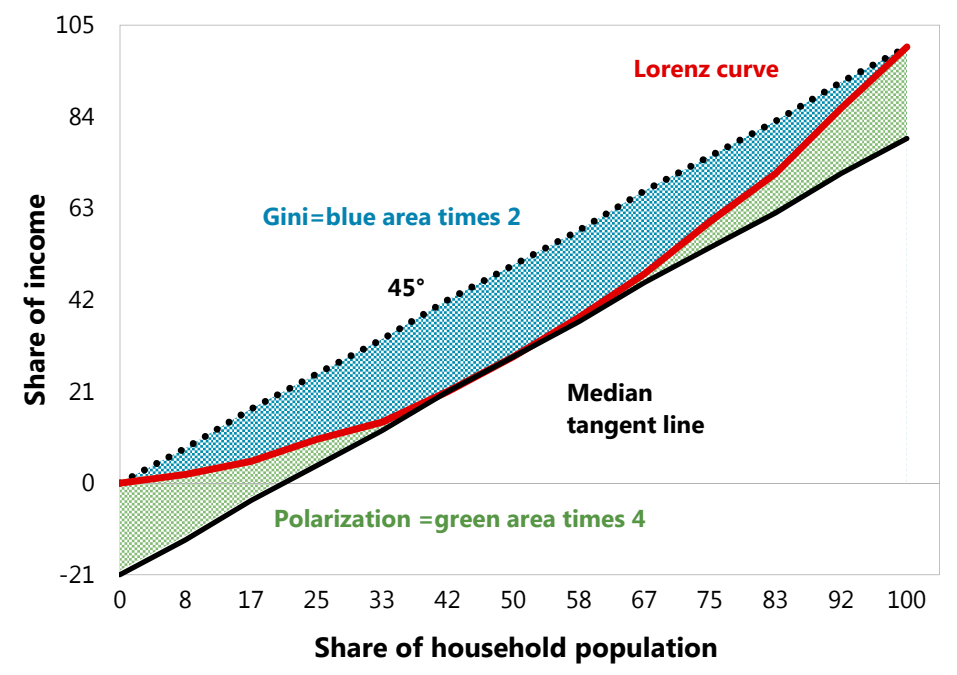

Source: Authors, based on Wolfson (1994).

In Appendix Figure 2, the 45-degree line represents zero polarity and perfect equality, and the median tangent is the line of concentration around median income. The median tangent is parallel to the line of zero polarity and perfect equality, because zero polarization and zero inequality both correspond to everyone having the same income. The distance from the 45-degree line shows the degree of inequality while the distance from the median tangent shows the degree of polarization. Hence, the green and blue areas provide metrics for measuring polarization and inequality, respectively. The curve comes closer to the median tangent if there is a higher concentration of population in the middle of the distribution. The polarization index is constructed to be 4 times this area, so the index ranges from 0 (no polarity) to 1 (bipolarity).

The Wolfson's index of polarization can be analytically written as follows:

$$
P=4 \times\left(0.5-\text { Income Share of Bottom } 50 \%-\frac{\text { Gini Coefficient }}{2}\right) *\left(\frac{\text { mean income }}{\text { median income }}\right)
$$

\footnotetext{
${ }^{1}$ This index of polarization is also used by Esteban and Ray (2007) and Wolfson and Foster (2010). Some literature has looked at polarization from the perspective of the 50/10 and 90/10 percentile ratios, mainly for wages. Examples for the latter measures could be found in Autor et al (2006) and Mishel et al (2013).
} 
Before continuing, it would be helpful to consider two illustrative examples for the extreme cases of no polarity and bipolarity:

- No polarity: consider a distribution of only 2 households, both of whom have income of $\$ 1$. In this case the polarization index is equal to 0 . This is because for this distribution, the income share of the bottom 50 percent is 0.5 ; Gini coefficient is 0 ; and the mean is equal to median $(\mathrm{P}=4 *(0.5-0.5-0 / 2) * 1=0)$.

- Bipolarity: now consider a distribution of only 2 households, one of whom with income of $\$ 0$ and the other one with income of $\$ 1$. In this case the polarization index is equal to 1 . The income share of the bottom 50 percent is equal to 0 ; the Gini coefficient is 0.5 ; and the mean is equal to median $(\mathrm{P}=4 *(0.5-0-0.5 / 2) * 1=1)$.

Figure 4 calculates this index for the United States at the national level since the 1970s using the CPS data.

A drawback of Wolfson's polarization index is that it is hard to break down to downward polarization (from middle- to low-income ranks) and upward polarization (from middle- to high-income ranks). This distinction is very important for policymakers. In addition, we are not aware of an economic interpretation of Wolfson's index, notwithstanding its statistical appeal. 


\section{Appendix IV. State-Level Regression Tables and Contributions}

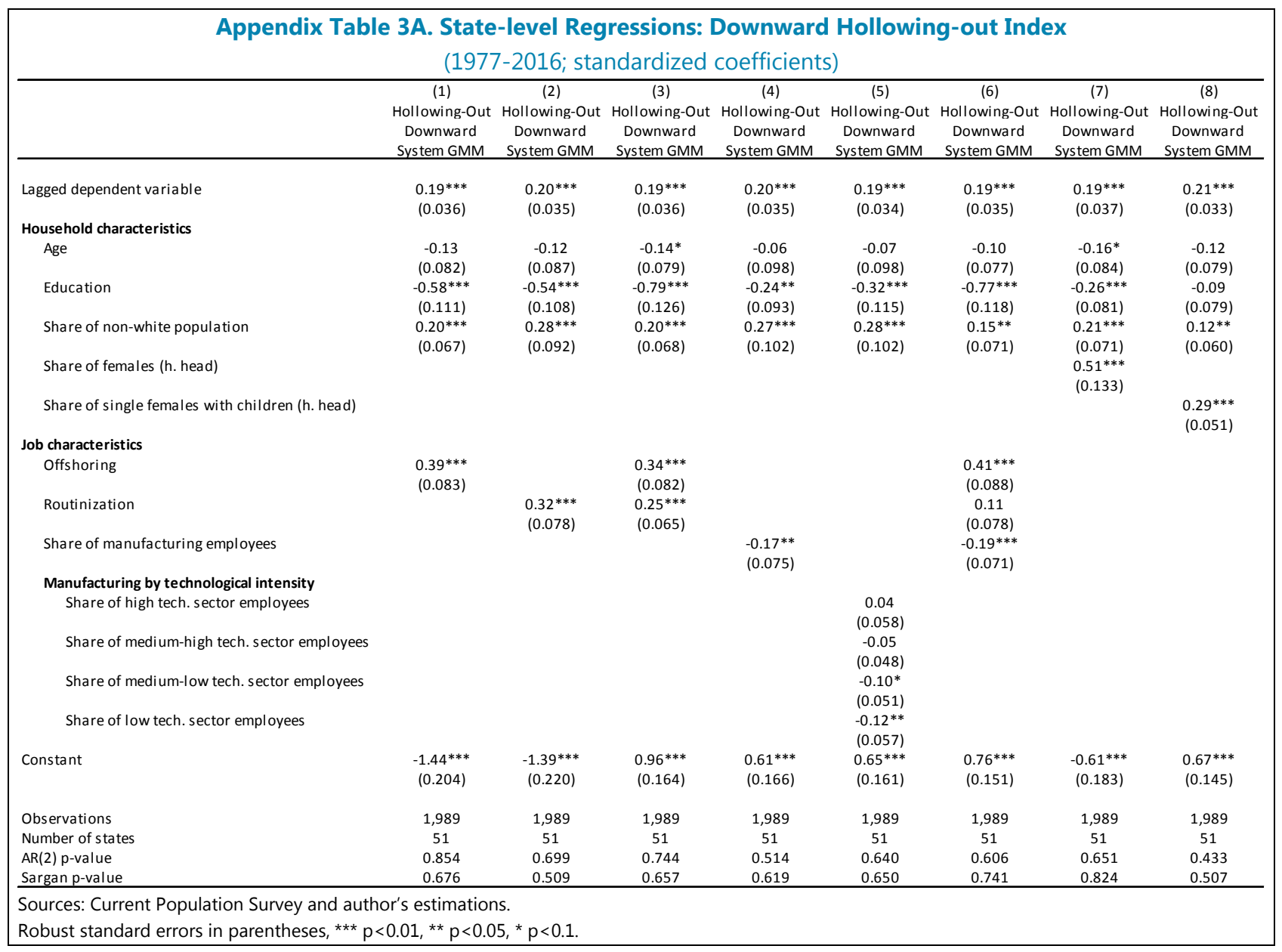


Appendix Figure 3A. Contributions to the Change in Downward Hollowing-Out Index (Percentage points)
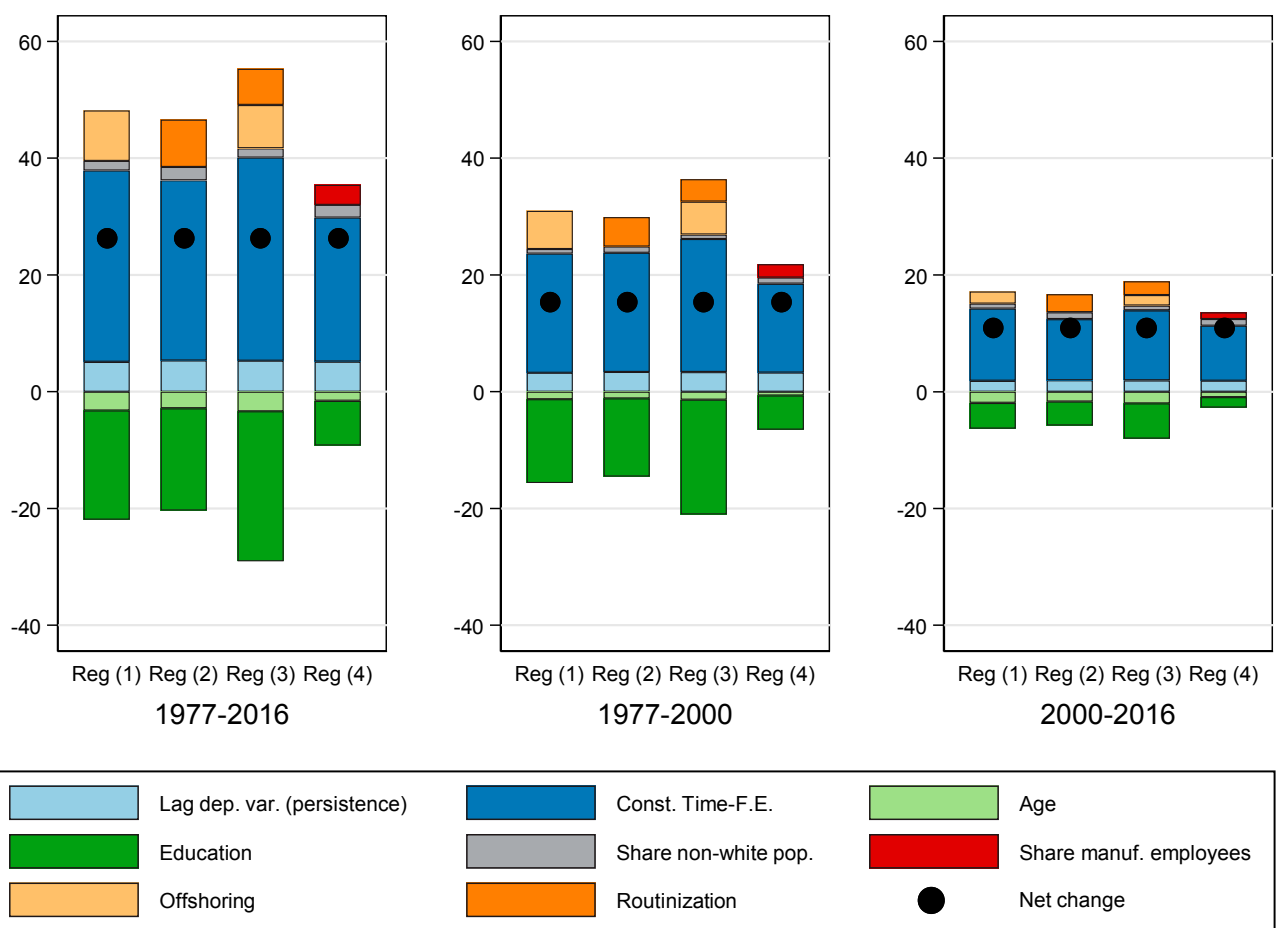

Sources: Current Population Survey and author's estimations.

Notes: coefficients estimation come from Table $6 \mathrm{~A}$ using state averages for the sample period. 


\begin{tabular}{|c|c|c|c|c|c|c|c|c|}
\hline \multicolumn{9}{|c|}{$\begin{array}{c}\text { Appendix Table 3B. State-level Regressions: Downward Population-Share Index } \\
\text { (1977-2016; standardized coefficients) }\end{array}$} \\
\hline & $\begin{array}{c}\text { (1) } \\
\text { Pop.Share } \\
\text { Downward } \\
\text { System GMM } \\
\end{array}$ & $\begin{array}{c}\text { (2) } \\
\text { Pop.Share } \\
\text { Downward } \\
\text { System GMM } \\
\end{array}$ & $\begin{array}{c}\text { (3) } \\
\text { Pop.Share } \\
\text { Downward } \\
\text { System GMM } \\
\end{array}$ & $\begin{array}{c}\text { (4) } \\
\text { Pop.Share } \\
\text { Downward } \\
\text { System GMM } \\
\end{array}$ & $\begin{array}{c}\text { (5) } \\
\text { Pop.Share } \\
\text { Downward } \\
\text { System GMM } \\
\end{array}$ & $\begin{array}{c}6) \\
\text { Pop.Share } \\
\text { Downward } \\
\text { System GMM }\end{array}$ & $\begin{array}{c}(7) \\
\text { Pop.Share } \\
\text { Downward } \\
\text { System GMM } \\
\end{array}$ & $\begin{array}{c}(8) \\
\text { Pop.Share } \\
\text { Downward } \\
\text { System GMM }\end{array}$ \\
\hline Lagged dependent variable & $\begin{array}{l}0.14^{* * * *} \\
(0.032)\end{array}$ & $\begin{array}{l}0.15^{* * *} \\
(0.032)\end{array}$ & $\begin{array}{c}0.14^{* * * *} \\
(0.033)\end{array}$ & $\begin{array}{l}0.15^{* * *} \\
(0.031)\end{array}$ & $\begin{array}{l}0.14^{* * * *} \\
(0.030)\end{array}$ & $\begin{array}{l}0.14^{* * *} \\
(0.032)\end{array}$ & $\begin{array}{l}0.14^{* * *} \\
(0.031)\end{array}$ & $\begin{array}{l}0.15^{* * *} \\
(0.029)\end{array}$ \\
\hline \multicolumn{9}{|l|}{ Household characteristics } \\
\hline Age & $\begin{array}{c}-0.12 \\
(0.097)\end{array}$ & $\begin{array}{c}-0.10 \\
(0.101)\end{array}$ & $\begin{array}{c}-0.12 \\
(0.094)\end{array}$ & $\begin{array}{c}-0.05 \\
(0.109)\end{array}$ & $\begin{array}{c}-0.05 \\
(0.109)\end{array}$ & $\begin{array}{c}-0.08 \\
(0.093)\end{array}$ & $\begin{array}{c}-0.14 \\
(0.096)\end{array}$ & $\begin{array}{c}-0.11 \\
(0.094)\end{array}$ \\
\hline Education & $\begin{array}{c}-0.65 * * * \\
(0.115)\end{array}$ & $\begin{array}{c}-0.60^{* * * *} \\
(0.119)\end{array}$ & $\begin{array}{c}-0.84 * * * \\
(0.132)\end{array}$ & $\begin{array}{c}-0.33^{* * *} \\
(0.101)\end{array}$ & $\begin{array}{c}-0.39 * * * \\
(0.123)\end{array}$ & $\begin{array}{c}-0.82 * * * \\
(0.124)\end{array}$ & $\begin{array}{c}-0.36 * * * \\
(0.088)\end{array}$ & $\begin{array}{l}-0.18 * * \\
(0.084)\end{array}$ \\
\hline Share of non-white population & $\begin{array}{l}0.23^{* * *} \\
(0.067)\end{array}$ & $\begin{array}{l}0.31^{* * *} \\
(0.091)\end{array}$ & $\begin{array}{c}0.23^{* * *} \\
(0.068)\end{array}$ & $\begin{array}{l}0.30^{* * *} \\
(0.099)\end{array}$ & $\begin{array}{l}0.31^{* * *} \\
(0.098)\end{array}$ & $\begin{array}{l}0.18^{* * *} \\
(0.070)\end{array}$ & $\begin{array}{l}0.23^{* * *} \\
(0.068)\end{array}$ & $\begin{array}{l}0.15^{* * *} \\
(0.055)\end{array}$ \\
\hline Share of females (h. head) & & & & & & & $\begin{array}{c}0.52^{* * *} \\
(0.120)\end{array}$ & \\
\hline Share of single females with children (h. head) & & & & & & & & $\begin{array}{l}0.30^{* * *} \\
(0.045)\end{array}$ \\
\hline \multicolumn{9}{|l|}{ Job characteristics } \\
\hline Offshoring & $\begin{array}{l}0.37 * * * \\
(0.081)\end{array}$ & & $\begin{array}{l}0.32^{* * *} \\
(0.082)\end{array}$ & & & $\begin{array}{l}0.39 * * * \\
(0.088)\end{array}$ & & \\
\hline Routinization & & $\begin{array}{l}0.29 * * * \\
(0.083)\end{array}$ & $\begin{array}{l}0.22^{* * * *} \\
(0.071)\end{array}$ & & & $\begin{array}{c}0.09 \\
(0.094)\end{array}$ & & \\
\hline Share of manufacturing employees & & & & $\begin{array}{l}-0.16 * * \\
(0.077)\end{array}$ & & $\begin{array}{l}-0.18 * * \\
(0.082)\end{array}$ & & \\
\hline \multicolumn{9}{|l|}{ Manufacturing by technological intensity } \\
\hline Share of high tech. sector employees & & & & & $\begin{array}{c}0.03 \\
(0.060)\end{array}$ & & & \\
\hline Share of medium-high tech. sector employees & & & & & $\begin{array}{c}-0.03 \\
(0.047)\end{array}$ & & & \\
\hline Share of medium-low tech. sector employees & & & & & $\begin{array}{l}-0.10^{*} \\
(0.051)\end{array}$ & & & \\
\hline Share of low tech. sector employees & & & & & $\begin{array}{l}-0.10^{*} \\
(0.059)\end{array}$ & & & \\
\hline Constant & $\begin{array}{l}0.93 * * * \\
(0.203)\end{array}$ & $\begin{array}{c}-1.40^{* * *} \\
(0.228)\end{array}$ & $\begin{array}{c}-1.56^{* * *} \\
(0.218)\end{array}$ & $\begin{array}{c}-1.14^{* * *} \\
(0.233)\end{array}$ & $\begin{array}{l}0.69 * * * \\
(0.202)\end{array}$ & $\begin{array}{l}0.85^{* * *} \\
(0.210)\end{array}$ & $\begin{array}{c}-0.01 \\
(0.168)\end{array}$ & $\begin{array}{l}0.72^{* * * *} \\
(0.184)\end{array}$ \\
\hline Observations & 1,989 & 1,989 & 1,989 & 1,989 & 1,989 & 1,989 & 1,989 & 1,989 \\
\hline Number of states & 51 & 51 & 51 & 51 & 51 & 51 & 51 & 51 \\
\hline$A R(2) p$-value & 0.644 & 0.324 & 0.561 & 0.399 & 0.495 & 0.691 & 0.492 & 0.325 \\
\hline Sargan $p$-value & 0.710 & 0.526 & 0.728 & 0.567 & 0.586 & 0.819 & 0.685 & 0.430 \\
\hline
\end{tabular}


Appendix Figure 3B. Contributions to the Change in Downward Population-Share Index (Percentage points)
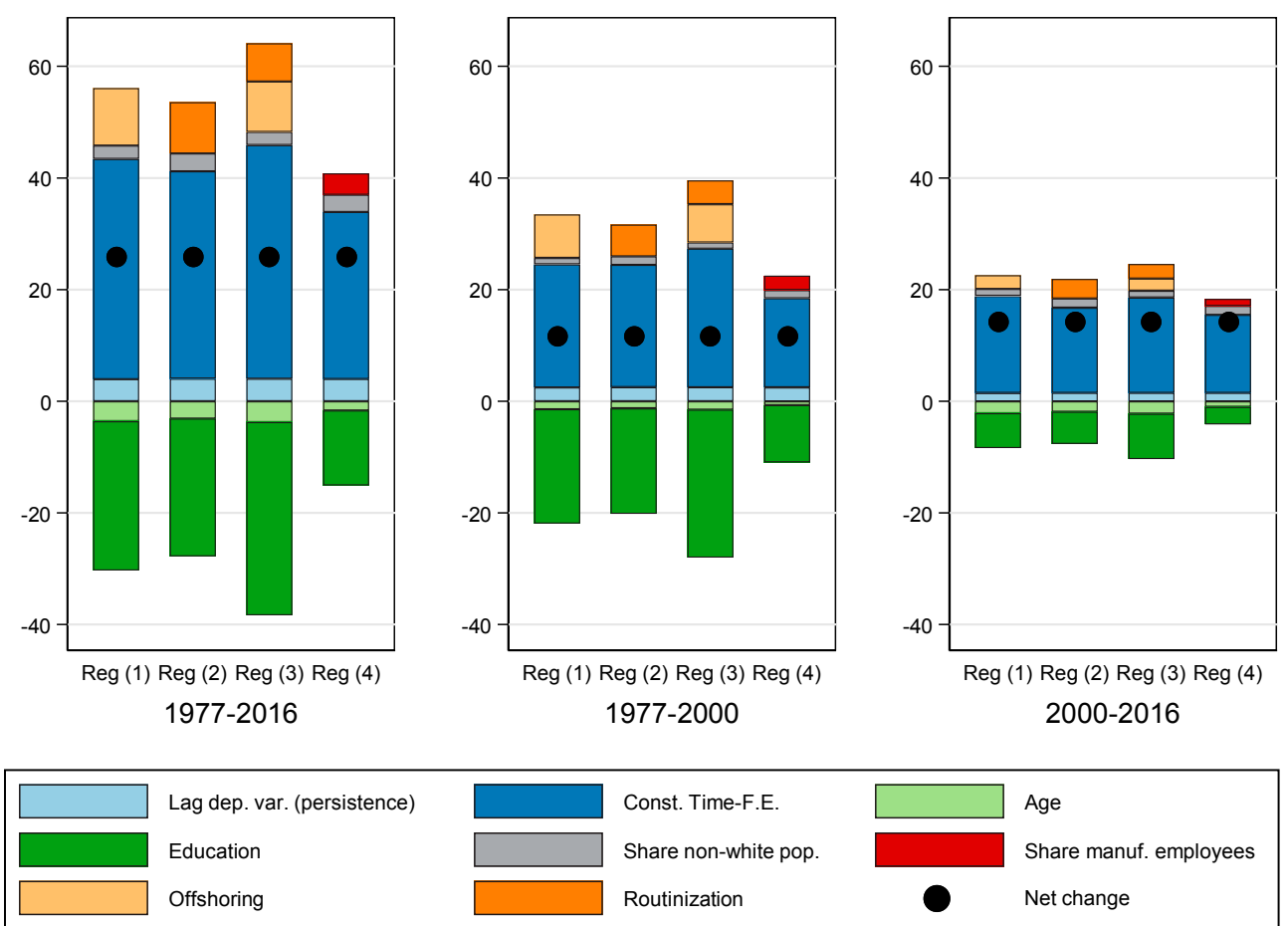

Sources: Current Population Survey and author's estimations.

Notes: coefficients estimation come from Table 6B using state averages for the sample period. 


\begin{tabular}{|c|c|c|c|c|c|c|c|c|}
\hline \multicolumn{9}{|c|}{$\begin{array}{l}\text { Appendix Table 4A. State-level Regressions: Upward Hollowing-out Index } \\
\text { (1977-2016; standardized coefficients) }\end{array}$} \\
\hline & $\begin{array}{c}1) \\
\text { Hollowing-Out } \\
\text { Upward } \\
\text { System GMM } \\
\end{array}$ & $\begin{array}{c}(2) \\
\text { Hollowing-Out } \\
\text { Upward } \\
\text { System GMM } \\
\end{array}$ & $\begin{array}{c}(3) \\
\text { Hollowing-Out } \\
\text { Upward } \\
\text { System GMM } \\
\end{array}$ & $\begin{array}{c}\text { (4) } \\
\text { Hollowing-Out } \\
\text { Upward } \\
\text { System GMM } \\
\end{array}$ & $\begin{array}{c}(5) \\
\text { Hollowing-Out } \\
\text { Upward } \\
\text { System GMM } \\
\end{array}$ & $\begin{array}{c}(6) \\
\text { Hollowing-Out } \\
\text { Upward } \\
\text { System GMM } \\
\end{array}$ & $\begin{array}{c}(7) \\
\text { Hollowing-Out } \\
\text { Upward } \\
\text { System GMM } \\
\end{array}$ & $\begin{array}{c}(8) \\
\text { Hollowing-Out } \\
\text { Upward } \\
\text { System GMM } \\
\end{array}$ \\
\hline Lagged dependent variable & $\begin{array}{l}0.15^{* * *} \\
(0.034)\end{array}$ & $\begin{array}{l}0.16^{* * *} \\
(0.034)\end{array}$ & $\begin{array}{l}0.15^{* * *} \\
(0.034)\end{array}$ & $\begin{array}{l}0.15^{* * *} \\
(0.033)\end{array}$ & $\begin{array}{l}0.15^{* * *} \\
(0.033)\end{array}$ & $\begin{array}{l}0.14^{* * *} \\
(0.033)\end{array}$ & $\begin{array}{l}0.15^{* * *} \\
(0.035)\end{array}$ & $\begin{array}{l}0.15^{* * *} \\
(0.035)\end{array}$ \\
\hline Household characteristics & & & & & & & & \\
\hline Age & $\begin{array}{c}-0.23 * * * \\
(0.064)\end{array}$ & $\begin{array}{c}-0.22 * * * \\
(0.069)\end{array}$ & $\begin{array}{c}-0.24^{* * *} \\
(0.062)\end{array}$ & $\begin{array}{c}-0.16 * * \\
(0.077)\end{array}$ & $\begin{array}{c}-0.17^{* *} \\
(0.074)\end{array}$ & $\begin{array}{c}-0.18^{* * *} \\
(0.057)\end{array}$ & $\begin{array}{c}-0.24^{* * *} \\
(0.067)\end{array}$ & $\begin{array}{c}-0.22 * * * \\
(0.063)\end{array}$ \\
\hline Education & $\begin{array}{c}-0.53^{* * *} \\
(0.109)\end{array}$ & $\begin{array}{c}-0.52^{* * *} \\
(0.107)\end{array}$ & $\begin{array}{c}-0.73 * * * \\
(0.127)\end{array}$ & $\begin{array}{c}-0.26 * * * \\
(0.074)\end{array}$ & $\begin{array}{c}-0.36 * * * \\
(0.094)\end{array}$ & $\begin{array}{c}-0.70^{* * *} \\
(0.118)\end{array}$ & $\begin{array}{c}-0.26^{* * *} \\
(0.073)\end{array}$ & $\begin{array}{c}-0.11^{*} \\
(0.068)\end{array}$ \\
\hline Share of non-white population & $\begin{array}{l}0.17^{* *} \\
(0.067)\end{array}$ & $\begin{array}{c}0.23 * * * \\
(0.087)\end{array}$ & $\begin{array}{l}0.17^{* *} \\
(0.068)\end{array}$ & $\begin{array}{l}0.21^{* *} \\
(0.096)\end{array}$ & $\begin{array}{l}0.23^{* *} \\
(0.099)\end{array}$ & $\begin{array}{c}0.11 \\
(0.071)\end{array}$ & $\begin{array}{l}0.18^{* *} \\
(0.071)\end{array}$ & $\begin{array}{c}0.10 \\
(0.062)\end{array}$ \\
\hline Share of females (h. head) & & & & & & & $\begin{array}{l}0.41^{* * *} \\
(0.133)\end{array}$ & \\
\hline Share of single females with children (h. head) & & & & & & & & $\begin{array}{c}0.26 * * * \\
(0.055)\end{array}$ \\
\hline Job characteristics & & & & & & & & \\
\hline Offshoring & $\begin{array}{l}0.32 * * * \\
(0.083)\end{array}$ & & $\begin{array}{c}0.28^{* * *} \\
(0.087)\end{array}$ & & & $\begin{array}{l}0.37 * * * \\
(0.091)\end{array}$ & & \\
\hline Routinization & & $\begin{array}{l}0.29 * * * \\
(0.076)\end{array}$ & $\begin{array}{c}0.23^{* * *} \\
(0.074)\end{array}$ & & & $\begin{array}{c}0.06 \\
(0.073)\end{array}$ & & \\
\hline Share of manufacturing employees & & & & $\begin{array}{c}-0.21 * * * \\
(0.076)\end{array}$ & & $\begin{array}{c}-0.23^{* * *} \\
(0.066)\end{array}$ & & \\
\hline Manufacturing by technological intensity & & & & & & & & \\
\hline Share of high tech. sector employees & & & & & $\begin{array}{c}0.06 \\
(0.051)\end{array}$ & & & \\
\hline Share of medium-high tech. sector employees & & & & & $\begin{array}{l}-0.10^{*} \\
(0.056)\end{array}$ & & & \\
\hline Share of medium-low tech. sector employees & & & & & $\begin{array}{c}-0.05 \\
(0.052)\end{array}$ & & & \\
\hline Share of low tech. sector employees & & & & & $\begin{array}{c}-0.16^{* * *} \\
(0.056)\end{array}$ & & & \\
\hline Constant & $\begin{array}{l}1.02 * * * \\
(0.153)\end{array}$ & $\begin{array}{l}1.03 * * * \\
(0.164)\end{array}$ & $\begin{array}{c}-1.61^{* * *} \\
(0.191)\end{array}$ & $\begin{array}{c}-1.18^{* * *} \\
(0.212)\end{array}$ & $\begin{array}{c}0.79 * * * \\
(0.161)\end{array}$ & $\begin{array}{c}-1.45^{* * *} \\
(0.192)\end{array}$ & $\begin{array}{c}0.56^{* * *} \\
(0.163)\end{array}$ & $\begin{array}{c}0.84^{* * *} \\
(0.133)\end{array}$ \\
\hline Observations & 1,989 & 1,989 & 1,989 & 1,989 & 1,989 & 1,989 & 1,989 & 1,989 \\
\hline Number of states & 51 & 51 & 51 & 51 & 51 & 51 & 51 & 51 \\
\hline AR(2) p-value & 0.509 & 0.748 & 0.540 & 0.799 & 0.874 & 0.527 & 0.634 & 0.862 \\
\hline Sargan $p$-value & 0.760 & 0.829 & 0.794 & 0.823 & 0.837 & 0.766 & 0.843 & 0.871 \\
\hline
\end{tabular}




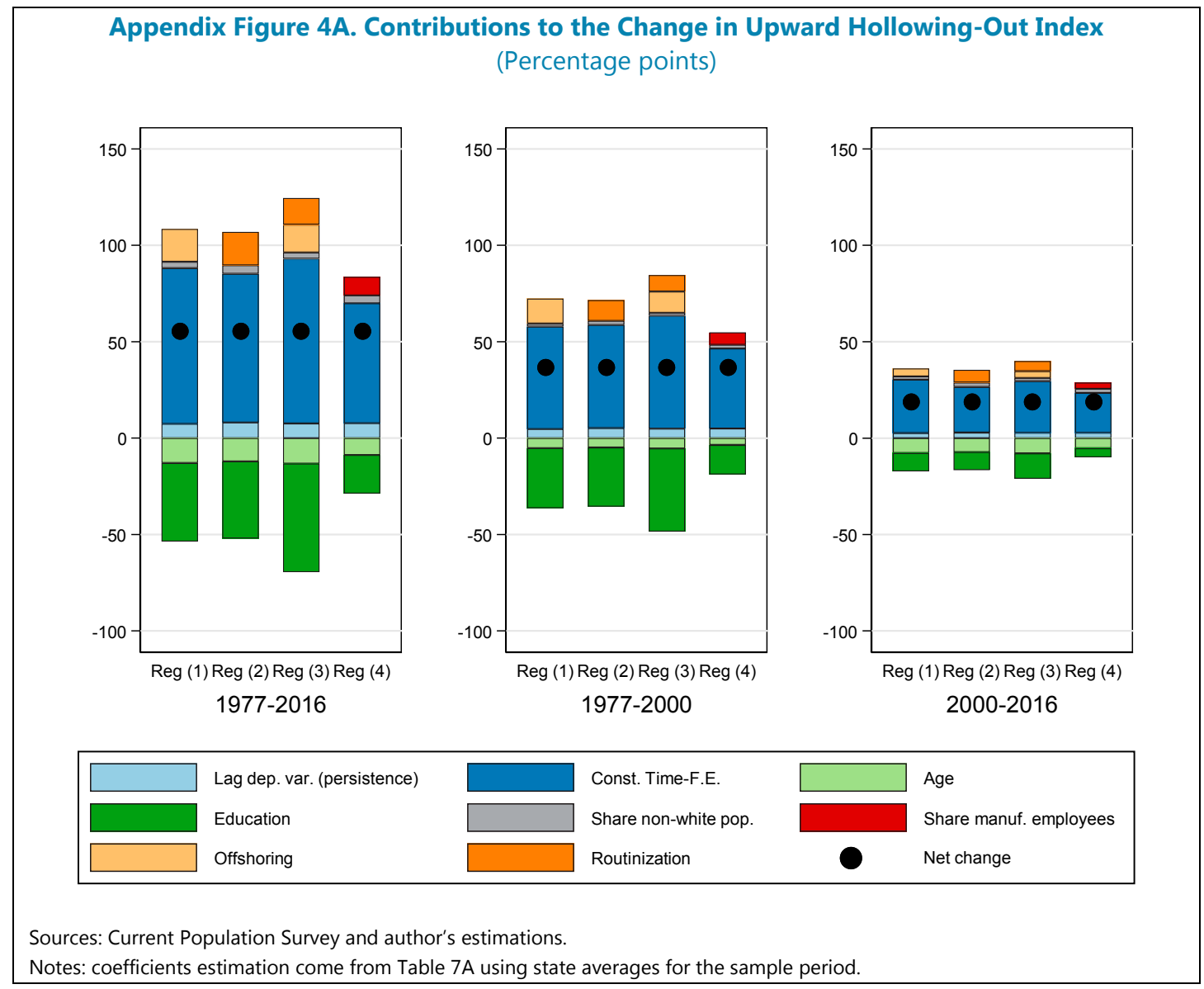

C)International Monetary Fund. Not for Redistribution 


\begin{tabular}{|c|c|c|c|c|c|c|c|c|}
\hline \multicolumn{9}{|c|}{$\begin{array}{c}\text { Appendix Table 4B. State-level Regressions: Upward Population-Share Index } \\
\text { (1977-2016; standardized coefficients) }\end{array}$} \\
\hline & $\begin{array}{c}(1) \\
\text { Pop.Share } \\
\text { Upward } \\
\text { System GMM } \\
\end{array}$ & $\begin{array}{c}(2) \\
\text { Pop.Share } \\
\text { Upward } \\
\text { System GMM } \\
\end{array}$ & $\begin{array}{c}\text { (3) } \\
\text { Pop.Share } \\
\text { Upward } \\
\text { System GMM } \\
\end{array}$ & $\begin{array}{c}(4) \\
\text { Pop.Share } \\
\text { Upward } \\
\text { System GMM } \\
\end{array}$ & $\begin{array}{c}5) \\
\text { Pop.Share } \\
\text { Upward } \\
\text { System GMM } \\
\end{array}$ & $\begin{array}{c}6) \\
\text { Pop.Share } \\
\text { Upward } \\
\text { System GMM } \\
\end{array}$ & $\begin{array}{c}\text { (7) } \\
\text { Pop.Share } \\
\text { Upward } \\
\text { System GMM } \\
\end{array}$ & $\begin{array}{c}\text { (8) } \\
\text { Pop.Share } \\
\text { Upward } \\
\text { System GMM }\end{array}$ \\
\hline Lagged dependent variable & $\begin{array}{l}0.14^{* * *} \\
(0.033)\end{array}$ & $\begin{array}{l}0.16^{* * *} \\
(0.033)\end{array}$ & $\begin{array}{l}0.15 * * * \\
(0.034)\end{array}$ & $\begin{array}{l}0.15^{* * *} \\
(0.032)\end{array}$ & $\begin{array}{l}0.15^{* * *} \\
(0.032)\end{array}$ & $\begin{array}{l}0.14^{* * *} \\
(0.033)\end{array}$ & $\begin{array}{l}0.15^{* * *} \\
(0.033)\end{array}$ & $\begin{array}{l}0.15^{* * *} \\
(0.033)\end{array}$ \\
\hline \multicolumn{9}{|l|}{ Household characteristics } \\
\hline Age & $\begin{array}{c}-0.25 * * * \\
(0.067)\end{array}$ & $\begin{array}{c}-0.24^{* * *} \\
(0.071)\end{array}$ & $\begin{array}{c}-0.26^{* * * *} \\
(0.066)\end{array}$ & $\begin{array}{c}-0.18^{* *} \\
(0.077)\end{array}$ & $\begin{array}{c}-0.19 * * * \\
(0.074)\end{array}$ & $\begin{array}{c}-0.20^{* * *} \\
(0.060)\end{array}$ & $\begin{array}{c}-0.26^{* * *} \\
(0.071)\end{array}$ & $\begin{array}{c}-0.25^{* * * *} \\
(0.066)\end{array}$ \\
\hline Education & $\begin{array}{c}-0.49^{* * *} \\
(0.112)\end{array}$ & $\begin{array}{c}-0.47^{* * *} \\
(0.112)\end{array}$ & $\begin{array}{c}-0.67^{* * *} \\
(0.132)\end{array}$ & $\begin{array}{c}-0.24 * * * \\
(0.076)\end{array}$ & $\begin{array}{c}-0.34 * * * \\
(0.097)\end{array}$ & $\begin{array}{c}-0.64^{* * *} \\
(0.121)\end{array}$ & $\begin{array}{c}-0.24 * * * \\
(0.078)\end{array}$ & $\begin{array}{c}-0.10 \\
(0.072)\end{array}$ \\
\hline Share of non-white population & $\begin{array}{l}0.18^{* * *} \\
(0.068)\end{array}$ & $\begin{array}{l}0.23 * * * \\
(0.086)\end{array}$ & $\begin{array}{l}0.17^{* *} \\
(0.068)\end{array}$ & $\begin{array}{l}0.21^{* *} \\
(0.095)\end{array}$ & $\begin{array}{l}0.23^{* *} \\
(0.097)\end{array}$ & $\begin{array}{c}0.11 \\
(0.071)\end{array}$ & $\begin{array}{l}0.18^{* *} \\
(0.072)\end{array}$ & $\begin{array}{l}0.10^{*} \\
(0.061)\end{array}$ \\
\hline Share of females (h. head) & & & & & & & $\begin{array}{l}0.37 * * * \\
(0.131)\end{array}$ & \\
\hline Share of single females with children (h. head) & & & & & & & & $\begin{array}{l}0.25 * * * \\
(0.053)\end{array}$ \\
\hline Job characteristics & & & & & & & & \\
\hline Offshoring & $\begin{array}{l}0.30 * * * \\
(0.082)\end{array}$ & & $\begin{array}{c}0.26 * * * \\
(0.087)\end{array}$ & & & $\begin{array}{l}0.35 * * * \\
(0.089)\end{array}$ & & \\
\hline Routinization & & $\begin{array}{l}0.26 * * * \\
(0.078)\end{array}$ & $\begin{array}{c}0.21 * * * \\
(0.077)\end{array}$ & & & $\begin{array}{c}0.03 \\
(0.074)\end{array}$ & & \\
\hline Share of manufacturing employees & & & & $\begin{array}{c}-0.21^{* * *} \\
(0.074)\end{array}$ & & $\begin{array}{c}-0.24 * * * \\
(0.064)\end{array}$ & & \\
\hline Manufacturing by technological intensity & & & & & & & & \\
\hline Share of high tech. sector employees & & & & & $\begin{array}{c}0.05 \\
(0.048)\end{array}$ & & & \\
\hline Share of medium-high tech. sector employees & & & & & $\begin{array}{c}-0.11^{* *} \\
(0.052)\end{array}$ & & & \\
\hline Share of medium-low tech. sector employees & & & & & $\begin{array}{c}-0.03 \\
(0.052)\end{array}$ & & & \\
\hline Share of low tech. sector employees & & & & & $\begin{array}{c}-0.16^{* * *} \\
(0.055)\end{array}$ & & & \\
\hline Constant & $\begin{array}{c}-1.29 * * * \\
(0.196)\end{array}$ & $\begin{array}{c}-1.26^{* * *} \\
(0.201)\end{array}$ & $\begin{array}{c}-1.39 * * * \\
(0.195)\end{array}$ & $\begin{array}{c}-0.99^{* * *} \\
(0.216)\end{array}$ & $\begin{array}{l}0.81^{* * *} \\
(0.168)\end{array}$ & $\begin{array}{l}0.80^{* * *} \\
(0.173)\end{array}$ & $\begin{array}{c}-0.66^{* * *} \\
(0.207)\end{array}$ & $\begin{array}{c}-0.84^{* * *} \\
(0.169)\end{array}$ \\
\hline Observations & 1,989 & 1,989 & 1,989 & 1,989 & 1,989 & 1,989 & 1,989 & 1,989 \\
\hline Number of states & 51 & 51 & 51 & 51 & 51 & 51 & 51 & 51 \\
\hline AR(2) p-value & 0.578 & 0.805 & 0.658 & 0.779 & 0.804 & 0.626 & 0.654 & 0.752 \\
\hline Sargan $p$-value & 0.569 & 0.635 & 0.582 & 0.637 & 0.621 & 0.546 & 0.581 & 0.707 \\
\hline
\end{tabular}


Appendix Figure 4B. Contributions to the Change in Upward Population-Share Index (Percentage points)
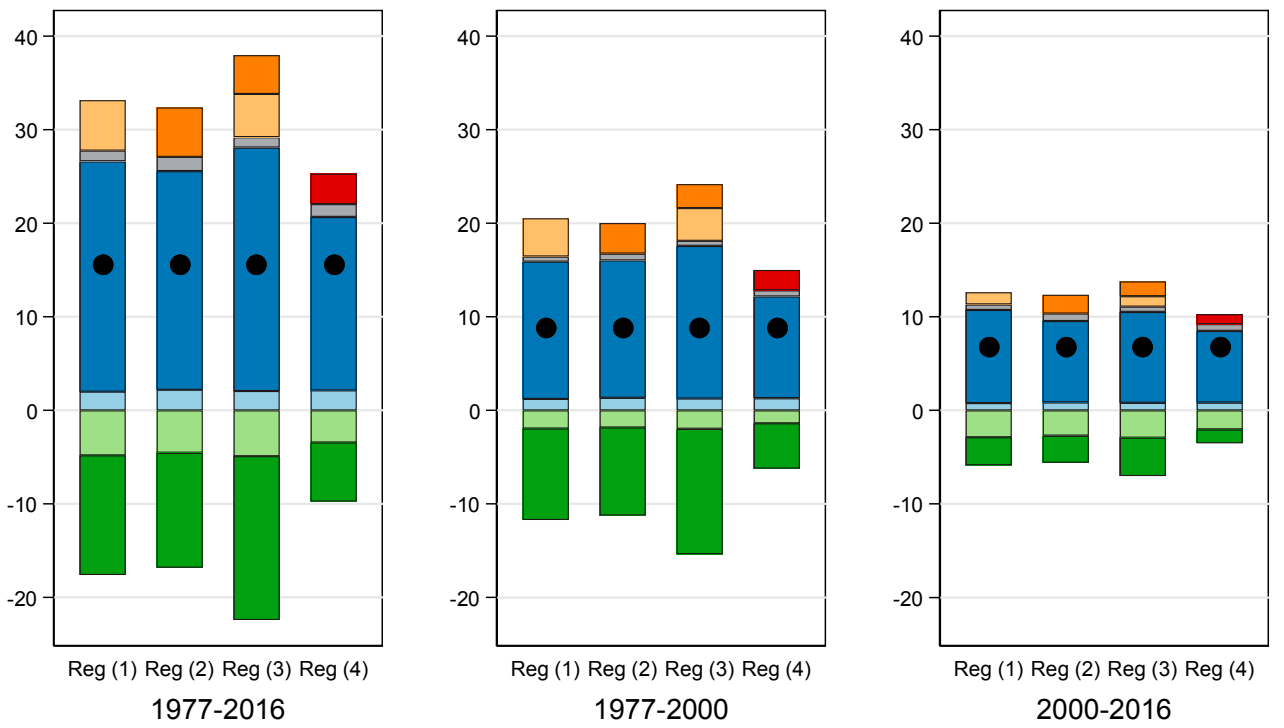

\begin{tabular}{|c|c|c|}
\hline Hag dep. var. (persistence) & Const. Time-F.E. & Age \\
\hline Education & Share non-white pop. & Share manuf. employees \\
\hline Offshoring & Routinization & Net change \\
\hline
\end{tabular}

Sources: Current Population Survey and author's estimations.

Notes: coefficients estimation come from Table 7B using state averages for the sample period. 


\section{Appendix V. Household-level Regression Tables}

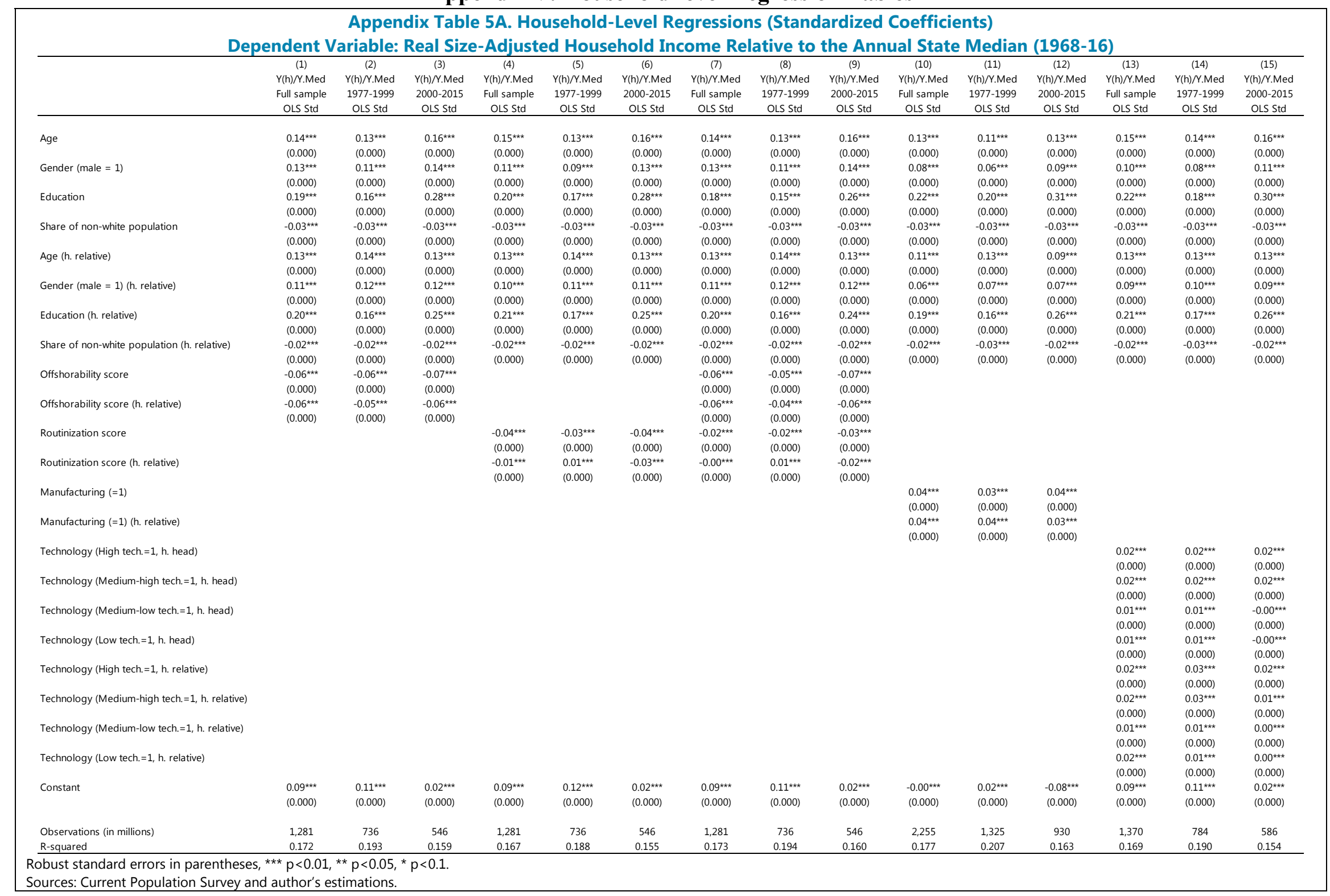




\begin{tabular}{|c|c|c|c|c|c|c|c|c|c|c|c|c|c|c|c|}
\hline \multicolumn{16}{|c|}{$\begin{array}{l}\text { Appendix Table 5B. Household-Level Quantile Regressions on the Median (Standardized Coefficients) } \\
\text { Dependent Variable: Real Size-Adjusted Household Income Relative to the Annual State Median (1968-16) }\end{array}$} \\
\hline & $(1)$ & (2) & 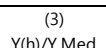 & (4) & $\begin{array}{c}(5) \\
Y(h) \gamma \operatorname{med}\end{array}$ & ${ }^{(6)}$ & $\stackrel{(7)}{(7)}$ & $(8)$ & $\frac{(9)}{y(h)}$ & $\begin{array}{c}(10) \\
y(h) \gamma(\operatorname{lod}\end{array}$ & $\begin{array}{c}(11) \\
Y(1) \gamma(n) d\end{array}$ & $\begin{array}{c}(12) \\
y(2)(2)\end{array}$ & $\begin{array}{c}(13) \\
\text { Y(b) } 13 \text { Med }\end{array}$ & 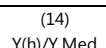 & $\begin{array}{c}(15) \\
Y(15) Y \operatorname{Med}\end{array}$ \\
\hline & $\begin{array}{l}Y(h) / Y \text {.Med } \\
\text { Full sample }\end{array}$ & $\begin{array}{l}Y(h) / Y . M e d \\
1977-1999\end{array}$ & $\begin{array}{l}\text { Y(h)/Y.Med } \\
2000-2015\end{array}$ & $\begin{array}{l}Y(h) / Y . M e d \\
\text { Full sample }\end{array}$ & $\begin{array}{l}Y(h) / Y . M e d \\
1977-1999\end{array}$ & $\begin{array}{l}Y(h) / Y . M e d \\
2000-2015\end{array}$ & $\begin{array}{l}Y(h) / \text { M.Med } \\
\text { Full sample }\end{array}$ & $\begin{array}{l}\text { (r) } 1 \text { (1)/.Med } \\
1977-1999\end{array}$ & $\begin{array}{l}\text { Yhn/r.Med } \\
2000-2015\end{array}$ & $\begin{array}{l}\text { Yhal/s.Med } \\
\text { Full sample }\end{array}$ & $\begin{array}{l}\text { (Yh)/PMed } \\
1977-1999\end{array}$ & $\begin{array}{l}\text { Yhh//.Med } \\
2000-2015\end{array}$ & $\begin{array}{l}\text { Yhil/ s.Med } \\
\text { Full sample }\end{array}$ & $\begin{array}{l}\text { Yhh//.Med } \\
\text { 1977-1999 }\end{array}$ & $\begin{array}{l}Y(h / / . M \text { Med } \\
2000-2015\end{array}$ \\
\hline & $\mathrm{Q}(0.50)$ & $\mathrm{Q}(0.50)$ & $\mathrm{Q}(0.50)$ & $\mathrm{Q}(0.50)$ & $\mathrm{Q}(0.50)$ & $\mathrm{Q}(0.50)$ & $\mathrm{Q}(0.50)$ & $\mathrm{Q}(0.50)$ & $\mathrm{Q}(0.50)$ & & $\mathrm{Q}(0.50)$ & $\mathrm{Q}(0.50)$ & $\mathrm{Q}(0.50)$ & $\mathrm{Q}(0.50)$ & $\mathrm{Q}(0.50)$ \\
\hline \multirow[t]{2}{*}{ Age } & $0.12^{* * *}$ & $0.11^{* * *}$ & $0.12^{* * *}$ & $0.12^{* * *}$ & $0.11^{* * *}$ & $0.12^{*+*}$ & $0.12^{* * *}$ & $0.11^{* * *}$ & $0.12^{* * *}$ & $0.10^{\star \star \star *}$ & $0.10^{\star \star * *}$ & $0.10^{\star \star * \star}$ & $0.12^{* \star *}$ & $0.12^{2 * *}$ & $0.12^{* \star * *}$ \\
\hline & $(0.000)$ & $(0.000)$ & $(0.000)$ & $(0.000)$ & $(0.000)$ & $(0.000)$ & $(0.000)$ & $(0.000)$ & $(0.000)$ & $(0.000)$ & $(0.000)$ & $(0.000)$ & $(0.000)$ & $(0.000)$ & $(0.000)$ \\
\hline \multirow{2}{*}{ Gender (male = 1) } & $0.10^{\star \star \star *}$ & $0.09 * \star x$ & $0.09 * \star x$ & $0.09 * \star *$ & $0.07^{* \star \star}$ & $0.08^{* \star \star}$ & $0.10^{\star \star \star \star}$ & $0.09 * \star *$ & $0.09 t * k$ & $0.07^{7 \star \star \star}$ & $0.05^{\star \star \star *}$ & $0.06^{\star \star * *}$ & $0.08^{* \star \star}$ & $0.06^{\star \star \star}$ & $0.07 * \star x$ \\
\hline & $(0.000)$ & $(0.000)$ & $(0.000)$ & $(0.000)$ & $(0.000)$ & $(0.000)$ & $(0.000)$ & $(0.000)$ & $(0.000)$ & $(0.000)$ & $(0.000)$ & $(0.000)$ & $(0.000)$ & $(0.000)$ & $(0.000)$ \\
\hline \multirow[t]{2}{*}{ Education } & $0.14^{\star \star \star}$ & $0.12^{\star \star \star \star}$ & $0.21^{* * *}$ & $0.15^{* \star *}$ & $0.13^{* * *}$ & $0.21^{\star \star \star \star}$ & $0.14^{* * *}$ & $0.12^{\star \star * *}$ & $0.20^{* * *}$ & $0.16^{* * *}$ & $0.15^{* \star *}$ & $0.24^{* * *}$ & $0.16^{* \star *}$ & $0.14^{* \star *}$ & $0.22^{\star \star *}$ \\
\hline & $(0.000)$ & $(0.000)$ & $(0.000)$ & $(0.000)$ & $(0.000)$ & $(0.000)$ & $(0.000)$ & $(0.000)$ & $(0.000)$ & $(0.000)$ & $(0.000)$ & $(0.000)$ & $(0.000)$ & $(0.000)$ & $(0.000)$ \\
\hline \multirow{2}{*}{ Share of non-white population } & $-0.03^{* \star \star}$ & $-0.03^{* k+k}$ & $-0.02^{2 * \star x}$ & $-0.03^{\star \star \star *}$ & $-0.03^{\star \star \star}$ & $-0.02^{2 * t}$ & $-0.03^{* \star * t}$ & $-0.03^{* t *}$ & $-0.02^{* \star *}$ & $-0.03^{* \star \star *}$ & $-0.03^{* \star \star x}$ & $-0.03^{\star \star \star *}$ & $-0.03^{\star \star \star x}$ & $-0.03^{\star \star \star \star}$ & $-0.03^{* \star \star x}$ \\
\hline & $(0.000)$ & $(0.000)$ & $(0.000)$ & $(0.000)$ & $(0.000)$ & $(0.000)$ & $(0.000)$ & $(0.000)$ & $(0.000)$ & $(0.000)$ & $(0.000)$ & $(0.000)$ & $(0.000)$ & $(0.000)$ & $(0.000)$ \\
\hline \multirow[t]{2}{*}{ Age (h. relative) } & $0.11^{\star \star \star}$ & $0.12^{\star \star \star *}$ & $0.11^{\star \star \star *}$ & $0.10^{* \star *}$ & $0.12^{\star \star \star \star}$ & $0.11^{1 * *}$ & $0.11^{\star \star *}$ & $0.12^{* * *}$ & $0.11^{* * *}$ & $0.09^{* * *}$ & $0.11^{* * *}$ & $0.08^{* * *}$ & $0.10^{* * *}$ & $0.11^{1 \star \star *}$ & $0.11^{\star \star \star *}$ \\
\hline & $(0.000)$ & $(0.000)$ & $(0.000)$ & $(0.000)$ & $(0.000)$ & $(0.000)$ & $(0.000)$ & $(0.000)$ & $(0.000)$ & $(0.000)$ & $(0.000)$ & $(0.000)$ & $(0.000)$ & $(0.000)$ & $(0.000)$ \\
\hline \multirow{2}{*}{ Gender $($ male $=1)($ h. relative $)$} & $0.07^{\star * *}$ & $0.08^{* \star *}$ & $0.07^{* \star *}$ & $0.05^{* \star *}$ & $0.06^{* \star \star}$ & $0.06^{* \star *}$ & $0.07^{\star \star \star *}$ & $0.07^{7 * * *}$ & $0.07^{7 * *}$ & $0.03^{* * *}$ & $0.04^{* * *}$ & $0.04^{* * *}$ & $0.05^{* \star \star}$ & $0.06^{* * *}$ & $0.05^{* * t}$ \\
\hline & $(0.000)$ & $(0.000)$ & $(0.000)$ & $(0.000)$ & $(0.000)$ & $(0.000)$ & $(0.000)$ & $(0.000)$ & $(0.000)$ & $(0.000)$ & $(0.000)$ & $(0.000)$ & $(0.000)$ & $(0.000)$ & $(0.000)$ \\
\hline \multirow{2}{*}{ Education (h. relative) } & $0.15^{\star \star *}$ & $0.14^{\star \star \star}$ & $0.19^{\star \star \star \star}$ & $0.16^{* \star *}$ & $0.15^{\star \star \star \star}$ & $0.19^{* \star \star *}$ & $0.15^{\star \star \star *}$ & $0.14^{\star \star \star \star}$ & $0.18^{* \star *}$ & $0.15^{\star \star \star}$ & $0.13^{\star \star \star *}$ & $0.20^{* \star \star *}$ & $0.16^{* \star *}$ & $0.15^{\star \star \star}$ & $0.20^{* \star \star *}$ \\
\hline & $(0.000)$ & $\begin{array}{l}(0.000) \\
(144\end{array}$ & $(0.000)$ & $(0.000)$ & $(0.000)$ & $(0.000)$ & $(0.000)$ & $\begin{array}{l}(0.000) \\
(1.49\end{array}$ & $\begin{array}{l}(0.000) \\
(0.000\end{array}$ & $(0.000)$ & $(0.000)$ & $(0.000)$ & $(0.000)$ & $(0.000)$ & $(0.000)$ \\
\hline \multirow[t]{2}{*}{ Share of non-white population (h. relative) } & $\begin{array}{l}-0.02 * * t \\
y\end{array}$ & 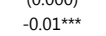 & $-0.02^{2 *+\pi}$ & $-0.02^{2 * * *}$ & $-0.02^{2 * * *}$ & $-0.01^{* * *}$ & $-0.02^{2 * *}$ & $-0.02^{* \star *+}$ & $-0.02^{* * *}$ & 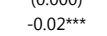 & $-0.02^{2 * \star}$ & $-0.02^{2 *+}$ & $-0.02^{* \star * \pi}$ & 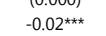 & $-0.00^{* \star *}$ \\
\hline & $(0.000)$ & $(0.000)$ & $(0.000)$ & $(0.000)$ & $(0.000)$ & $(0.000)$ & $(0.000)$ & $(0.000)$ & $(0.000)$ & $(0.000)$ & $(0.000)$ & $(0.000)$ & $(0.000)$ & $(0.000)$ & $(0.000)$ \\
\hline \multirow[t]{2}{*}{ Offshorability score } & $-0.05^{* \star *}$ & $-0.04^{4 * x}$ & $-0.04^{* * *}$ & & & & $-0.04 * *$ & $-0.04 * \star x$ & $-0.04^{* *+}$ & & & & & & \\
\hline & $(0.000)$ & $(0.000)$ & $(0.000)$ & & & & $(0.000)$ & $(0.000)$ & $(0.000)$ & & & & & & \\
\hline \multirow{2}{*}{ Offshorability score (h. relative) } & $-0.04 * \star \star x$ & $-0.04 * \star x$ & $-0.04^{4 * x}$ & & & & $-0.04 * *$ & $-0.04^{* t *}$ & $-0.04 * \star *$ & & & & & & \\
\hline & $(0.000)$ & $(0.000)$ & $(0.000)$ & & & & $(0.000)$ & $(0.000)$ & $(0.000)$ & & & & & & \\
\hline \multirow[t]{2}{*}{ Routinization score } & & & & $-0.02^{* \star *}$ & $-0.02^{* * *}$ & $-0.02^{* * *}$ & $-0.01^{* * *}$ & $-0.00^{* * *}$ & $-0.00^{* * *}$ & & & & & & \\
\hline & & & & $(0.000)$ & $(0.000)$ & $(0.000)$ & $(0.000)$ & $(0.000)$ & $(0.000)$ & & & & & & \\
\hline \multirow[t]{2}{*}{ Routinization score (h. relative) } & & & & $0.01^{* \star *}$ & $0.02^{* \star *}$ & $-0.00^{* * *}$ & $0.01^{* * *}$ & $0.02^{* * *}$ & $-0.01^{* * *}$ & & & & & & \\
\hline & & & & $(0.000)$ & $(0.000)$ & $(0.000)$ & $(0.000)$ & $(0.000)$ & $(0.000)$ & & & & & & \\
\hline Manufacturing (=1) & & & & & & & & & & $\begin{array}{l}0.04^{* \star *} \\
0.000\end{array}$ & $\begin{array}{l}0.03^{* * *} \\
0.000\end{array}$ & $\begin{array}{l}0.04^{4 * *} \\
(0.000\end{array}$ & & & \\
\hline \multirow[t]{2}{*}{ Manufacturing $(=1)$ (h. relative) } & & & & & & & & & & $0.04^{4 * *}$ & $0.04^{* * *}$ & $0.03^{* * *}$ & & & \\
\hline & & & & & & & & & & $(0.000)$ & $(0.000)$ & $(0.000)$ & & & \\
\hline \multirow[t]{2}{*}{ Technology (High tech. $=1$, h. head) } & & & & & & & & & & & & & $0.02^{2 * *}$ & $0.02^{2 * *}$ & $0.02^{* \star *}$ \\
\hline & & & & & & & & & & & & & $(0.000)$ & $(0.000)$ & $(0.000)$ \\
\hline \multirow[t]{2}{*}{ Technology (Medium-high tech. $=1$, h. head) } & & & & & & & & & & & & & $0.02^{2 * *}$ & $0.02^{2 * *}$ & $0.02^{* \star *}$ \\
\hline & & & & & & & & & & & & & $(0.000)$ & $(0.000)$ & $(0.000)$ \\
\hline Technology (Medium-low tech. $=1$, h. head) & & & & & & & & & & & & & $0.00^{* \star *}$ & $0.01^{\star \star \star *}$ & $-0.00 * \star *$ \\
\hline & & & & & & & & & & & & & $(0.000)$ & $(0.000)$ & $(0.000)$ \\
\hline Technology (Low tech. $=1$, h. head) & & & & & & & & & & & & & $0.00^{\star * *}$ & $0.01^{\star \star \star *}$ & $0.00^{* * *}$ \\
\hline Technology (High tech $=1, \mathrm{~h}$, relative) & & & & & & & & & & & & & $\begin{array}{l}(0.000) \\
0.02 * *\end{array}$ & $\begin{array}{l}(0.000) \\
0.02 * \star\end{array}$ & $\begin{array}{l}(0.000) \\
0.02^{* * *}\end{array}$ \\
\hline & & & & & & & & & & & & & $(0.000)$ & $(0.000)$ & $(0.000)$ \\
\hline Technology (Medium-high tech. $=1$, h. relative) & & & & & & & & & & & & & $0.03^{* \star *}$ & $0.03^{* \star *}$ & $0.02^{* * *}$ \\
\hline & & & & & & & & & & & & & $(0.000)$ & $(0.000)$ & $(0.000)$ \\
\hline Technology (Medium-low tech. $=1$, h. relative) & & & & & & & & & & & & & $0.00^{\star * *}$ & $0.01^{\star \star \star}$ & $0.00^{* * *+}$ \\
\hline & & & & & & & & & & & & & $(0.000)$ & $(0.000)$ & $(0.000)$ \\
\hline Technology (Low tech. $=1$, h. relative) & & & & & & & & & & & & & $0.02^{2 \star \star *}$ & $0.01^{* \star *}$ & $0.00^{* * *}$ \\
\hline Constant & $-0.05^{* * *}$ & $-0.02^{*+* *}$ & $-0.12^{2 \star * *}$ & $-0.05^{* * *}$ & $-0.02^{* * *}$ & $-0.13^{* * *}$ & $-0.05^{* * *}$ & $-0.02^{* * *}$ & $-0.12^{* * *}$ & $-0.16^{* \star *}$ & $-0.13^{* * *}$ & $-0.23^{* * *}$ & $-0.05^{* * *}$ & $-0.02^{* * *}$ & $-0.12^{* * *}$ \\
\hline & $(0.000)$ & $(0.000)$ & $(0.000)$ & $(0.000)$ & $(0.000)$ & $(0.000)$ & $(0.000)$ & $(0.000)$ & $(0.000)$ & $(0.000)$ & $(0.000)$ & $(0.000)$ & $(0.000)$ & $(0.000)$ & $(0.000)$ \\
\hline Observations (in millions) & 1,281 & 736 & 546 & 1,281 & 736 & 546 & 1,281 & 736 & 546 & 2.255 & 1.325 & 930 & 1,370 & 784 & 586 \\
\hline
\end{tabular}




\begin{tabular}{|c|c|c|c|c|c|c|c|c|c|c|c|c|c|c|c|}
\hline \multicolumn{16}{|c|}{$\begin{array}{l}\text { Appendix Table 6A. Household-Level Quantile Regressions on the Median (Standardized Coefficients) } \\
\text { Dependent Variable: Real Size-Adjusted Household Income Relative to the Annual State Median (1968-16) }\end{array}$} \\
\hline & $\begin{array}{c}(1) \\
\text { Y(h) } Y \text {.Med } \\
\text { Full sample } \\
\text { Q(0.25) } \\
\end{array}$ & $\begin{array}{c}(2) \\
Y(h) / Y . M e d \\
1977-1999 \\
Q(0.25) \\
\end{array}$ & $\begin{array}{c}(3) \\
Y(h) / . M e d \\
2000-2015 \\
Q(0.25)\end{array}$ & $\begin{array}{c}(4) \\
Y(h) / Y . M e d \\
\text { Full sample } \\
\text { Q(0.25) }\end{array}$ & $\begin{array}{c}\text { (5) } \\
Y(h) / N \cdot M e d \\
1977-1999 \\
Q(0.25) \\
\end{array}$ & $\begin{array}{c}(6) \\
Y(h) / / . M e d \\
2000-2015 \\
Q(0.25) \\
\end{array}$ & $\begin{array}{c}\text { (7) } \\
\text { Y(h)/Y.Med } \\
\text { Full sample } \\
\text { Q(0.25) }\end{array}$ & $\begin{array}{c}(8) \\
Y(h) / Y . M e d \\
1977-1999 \\
Q(0.25) \\
\end{array}$ & $\begin{array}{c}\text { (9) } \\
\text { Y(h) N.Med } \\
2000-2015 \\
\text { Q(0.25) }\end{array}$ & $\begin{array}{c}(10) \\
\text { Y(h)/.Med } \\
\text { Full sample } \\
\text { Q(0.25) }\end{array}$ & $\begin{array}{c}(11) \\
Y(h) / Y . M e d \\
1977-1999 \\
Q(0.25) \\
\end{array}$ & $\begin{array}{c}(12) \\
\text { Y(h)/Y.Med } \\
2000-2015 \\
Q(0.25)\end{array}$ & $\begin{array}{c}\text { (13) } \\
\text { Y(h) } N \text {.Med } \\
\text { Full sample } \\
\text { Q(0.25) }\end{array}$ & $\begin{array}{c}(14) \\
Y(h) / Y . M e d \\
1977-1999 \\
Q(0.25)\end{array}$ & $\begin{array}{c}(15) \\
Y(h) / . M \text {. } \\
2000-2015 \\
Q(0.25) \\
\end{array}$ \\
\hline Age & $0.08^{+*+*}$ & $0.08^{\star \star \star *}$ & $0.08^{* \star *}$ & $0.08^{* * *}$ & $0.08^{* * *}$ & $0.08^{* \star *}$ & $0.08^{* * *}$ & $0.08^{\star \star \star *}$ & $0.08^{* \star *}$ & $0.06^{* \star \star *}$ & $0.07^{* \star * *}$ & $0.06^{* * *}$ & $0.09^{* \star *}$ & $0.09^{* \star *}$ & $0.08^{*+*+1}$ \\
\hline Gender $($ male $=1)$ & $\begin{array}{l}(0.000) \\
0.07 * \star\end{array}$ & $\begin{array}{l}(0.000) \\
0.06^{* \star *}\end{array}$ & $\begin{array}{l}(0.000) \\
0.06^{* \star *}\end{array}$ & $\begin{array}{l}(0.000) \\
0.06^{* \star \star}\end{array}$ & $\begin{array}{l}(0.000) \\
0.05^{\star \star \star}\end{array}$ & $\begin{array}{l}(0.000) \\
0.05^{* * \star}\end{array}$ & $\begin{array}{l}(0.000) \\
0.07 \star \star \star\end{array}$ & $\begin{array}{l}(0.000) \\
0.06^{* * t}\end{array}$ & $\begin{array}{l}(0.000) \\
0.06^{* \star *}\end{array}$ & $\begin{array}{l}(0.000) \\
0.05^{* \star *}\end{array}$ & $\begin{array}{l}(0.000) \\
0.04^{\star \star \star}\end{array}$ & $\begin{array}{l}(0.000) \\
0.04^{* * *}\end{array}$ & $\begin{array}{l}(0.000) \\
0.05 * \star \star\end{array}$ & $\begin{array}{l}(0.000) \\
0.04^{* * *}\end{array}$ & $\begin{array}{l}(0.000) \\
0.05 * *+\end{array}$ \\
\hline & $(0.000)$ & $(0.000)$ & $(0.000)$ & $(0.000)$ & $(0.000)$ & $(0.000)$ & $(0.000)$ & $(0.000)$ & $(0.000)$ & $(0.000)$ & $(0.000)$ & $(0.000)$ & $(0.000)$ & $(0.000)$ & $(0.000)$ \\
\hline Education & $0.11^{\star \star \star}$ & $0.09^{\star \star *}$ & $0.15^{\star \star \star}$ & $0.11^{\star \star \star}$ & $0.10^{\star \star \star \star}$ & $0.15^{\star \star \star}$ & $0.11^{\star \star \star}$ & $0.09^{\star \star \star *}$ & $0.14^{\star \star \star *}$ & $0.12^{\star \star \star}$ & $0.11^{\star \star \star}$ & $0.17^{\star \star \star *}$ & $0.12^{\star \star \star}$ & $0.11^{\star \star \star}$ & $0.16^{* \star * *}$ \\
\hline & $(0.000)$ & $(0.000)$ & $(0.000)$ & $(0.000)$ & $(0.000)$ & $(0.000)$ & $(0.000)$ & $(0.000)$ & $(0.000)$ & $(0.000)$ & $(0.000)$ & $(0.000)$ & $(0.000)$ & $(0.000)$ & $(0.000)$ \\
\hline Share of non-white population & $\begin{array}{c}-0.03^{* * *} \\
(0.000)\end{array}$ & $\begin{array}{c}-0.02 * * * \\
(0.000)\end{array}$ & $\begin{array}{l}-0.02^{* * *} \\
(0.000)\end{array}$ & $\begin{array}{c}-0.02 * \star * * \\
(0.000)\end{array}$ & $\begin{array}{c}-0.00^{2 * * *} \\
(0.000)\end{array}$ & $\begin{array}{c}-0.02^{2 * *} \\
(0.000)\end{array}$ & $\begin{array}{c}-0.03^{*+* x} \\
(0.000)\end{array}$ & $\begin{array}{c}-0.03^{* \star * *} \\
(0.000)\end{array}$ & $\begin{array}{l}-0.02 * * * \\
(0.000)\end{array}$ & $\begin{array}{c}-0.02 * * * \\
(0.000)\end{array}$ & $\begin{array}{l}-0.03^{* \star *} \\
(0.000)\end{array}$ & $\begin{array}{l}-0.02 * \star * * \\
(0.000)\end{array}$ & $\begin{array}{c}-0.02^{* * *} \\
(0.000)\end{array}$ & $\begin{array}{c}-0.02 * \star * * \\
(0.000)\end{array}$ & $\begin{array}{c}-0.02^{* * *} \\
(0.000)\end{array}$ \\
\hline Age (h. relative) & $0.09^{* t * *}$ & $0.10^{* * *}$ & $0.09+* t$ & $0.09 * *$ & $0.09 * * \star x$ & $0.09 * *$ & $0.09^{* * *}$ & $0.10^{* * *}$ & $0.09 * * \star x$ & $0.06^{* * *}$ & $0.08^{* * *}$ & $0.06^{* *+}$ & $0.08^{* \star *}$ & $0.09 * \star \star$ & $0.09 * * t$ \\
\hline & $(0.000)$ & $(0.000)$ & $(0.000)$ & $(0.000)$ & $(0.000)$ & $(0.000)$ & $(0.000)$ & $(0.000)$ & $(0.000)$ & $(0.000)$ & $(0.000)$ & $(0.000)$ & $(0.000)$ & $(0.000)$ & $(0.000)$ \\
\hline Gender $($ male $=1)($ h. relative $)$ & $0.04^{\star \star \star *}$ & $0.05^{\star * *}$ & $0.04^{\star \star \star}$ & $0.03^{\star \star \star *}$ & $0.04^{\star \star \star}$ & $0.04^{\star \star \star *}$ & $0.04^{\star \star \star *}$ & $0.05^{\star \star *}$ & $0.04^{\star \star \star *}$ & $0.02^{\star \star \star}$ & $0.02^{\star \star \star}$ & $0.02^{\star \star \star}$ & $0.03^{\star \star \star}$ & $0.03^{\star \star \star *}$ & $0.03^{* \star *}$ \\
\hline & $(0.000)$ & $(0.000)$ & $(0.000)$ & $(0.000)$ & $(0.000)$ & $(0.000)$ & $(0.000)$ & $(0.000)$ & $(0.000)$ & $(0.000)$ & $(0.000)$ & $(0.000)$ & $(0.000)$ & $(0.000)$ & $(0.000)$ \\
\hline Education (h. relative) & $0.11^{\star \star \star *}$ & $0.10^{* * *}$ & $0.14^{* * *}$ & $0.12^{* * *}$ & $0.11^{\star \star \star}$ & $0.14^{* * *}$ & $0.12^{* \star *}$ & $0.11^{\star \star \star *}$ & $0.14^{* * *}$ & $0.11^{\star \star \star}$ & $0.10^{\star \star \star *}$ & $0.14^{* \star *}$ & $0.12^{\star \star \star \star}$ & $0.11^{\star \star \star}$ & $0.15^{*+* t}$ \\
\hline & $(0.000)$ & $(0.000)$ & $(0.000)$ & $(0.000)$ & $(0.000)$ & $(0.000)$ & $(0.000)$ & $(0.000)$ & $(0.000)$ & $(0.000)$ & $(0.000)$ & $(0.000)$ & $(0.000)$ & $(0.000)$ & $(0.000)$ \\
\hline Share of non-white population (h. relative) & $\begin{array}{l}-0.00^{1 * * x} \\
(0.000)\end{array}$ & $\begin{array}{l}-0.02 * * x \\
(0.000)\end{array}$ & $\begin{array}{l}-0.01^{*+*+x} \\
(0.000)\end{array}$ & $\begin{array}{l}-0.02 * \star \star \\
(0.000)\end{array}$ & $\begin{array}{l}-0.02 * \star x \\
(0.000)\end{array}$ & $\begin{array}{l}-0.01 * \star * \\
(0.000)\end{array}$ & $\begin{array}{l}-0.02 * * x \\
(0.000)\end{array}$ & $\begin{array}{c}-0.02 * \star x \\
(0.000)\end{array}$ & $\begin{array}{c}-0.01 * * * \\
(0.000)\end{array}$ & $\begin{array}{l}-0.02 * \star x \\
(0.000)\end{array}$ & $\begin{aligned}-0.02 * \star \star \\
(0.000)\end{aligned}$ & $\begin{array}{c}-0.02 * \star \\
(0.000)\end{array}$ & $\begin{array}{c}-0.02 * \star \\
(0.000)\end{array}$ & $\begin{array}{c}-0.02 * \star \\
(0.000)\end{array}$ & $\begin{array}{c}-0.01^{* \star *} \\
(0.000)\end{array}$ \\
\hline Offshorability score & $\begin{array}{l}(0.000) \\
-0.03^{* * *}\end{array}$ & $-0.03^{*+*}$ & $-0.03^{* * *}$ & & & & $-0.03^{* * *}$ & $-0.03^{* * *}$ & $-0.03^{* * *}$ & & & & & & \\
\hline & $(0.000)$ & $(0.000)$ & $(0.000)$ & & & & $(0.000)$ & $(0.000)$ & $(0.000)$ & & & & & & \\
\hline Offshorability score (h. relative) & $-0.03^{* * *}$ & $-0.03^{*+* *}$ & $-0.03^{* * * *}$ & & & & $-0.03^{* * * *}$ & $-0.03^{* * * *}$ & $-0.03^{* * *+}$ & & & & & & \\
\hline & $(0.000)$ & $(0.000)$ & $(0.000)$ & & & & $(0.000)$ & $(0.000)$ & $(0.000)$ & & & & & & \\
\hline Routinization score & & & & $\begin{array}{l}-0.00^{1 * \star} \\
(0.000)\end{array}$ & $\begin{array}{l}-0.00 * t * x \\
(0.000)\end{array}$ & $\begin{array}{c}-0.01^{\star \star *} \\
(0.000)\end{array}$ & $\begin{array}{l}0.00^{* * *} \\
(0.000)\end{array}$ & $\begin{array}{l}0.01^{\star \star \star} \\
(0.000)\end{array}$ & $\begin{array}{c}-0.00 * * * \\
(0.000)\end{array}$ & & & & & & \\
\hline Routinization score (h. relative) & & & & $0.01^{* * *}$ & $\begin{array}{l}0.00^{+t+k} \\
(0.000)\end{array}$ & $\begin{array}{c}-0.00^{+t+k} \\
(0.000)\end{array}$ & $\begin{array}{l}0.010+t+1 \\
(0.000)\end{array}$ & $0.01 * *$ & $-0.00 *+2$ & & & & & & \\
\hline Manufacturing (=1) & & & & (0.000) & & & & & & $0.04^{* \star \star *}$ & $0.04^{\star \star *}$ & $0.04^{* * *}$ & & & \\
\hline Manufacturing (=1) (h. relative) & & & & & & & & & & $\begin{array}{l}(0.000) \\
0.04^{* *+*}\end{array}$ & $\begin{array}{l}(0.000) \\
0.03^{* * *}\end{array}$ & $\begin{array}{l}(0.000) \\
0.03^{*+*+*}\end{array}$ & & & \\
\hline & & & & & & & & & & $(0.000)$ & $(0.000)$ & $(0.000)$ & & & \\
\hline Technology (High tech. $=1$, h. head) & & & & & & & & & & & & & $\begin{array}{l}0.02^{\star * \star} \\
(0.000)\end{array}$ & $\begin{array}{l}0.02^{\star * *} \\
(0.000)\end{array}$ & $\begin{array}{l}0.02^{* * *} \\
(0.0000)\end{array}$ \\
\hline Technology (Medium-high tech. $=1, \mathrm{~h}$. head) & & & & & & & & & & & & & $0.03^{\star \star \star}$ & $0.03^{\star \star \star *}$ & $0.02^{\star \star \star *}$ \\
\hline & & & & & & & & & & & & & $(0.000)$ & $(0.000)$ & $(0.000)$ \\
\hline Technology (Medium-low tech. $=1$, h. head) & & & & & & & & & & & & & $\begin{array}{l}0.01^{\star \star \star} \\
(0.000)\end{array}$ & $\begin{array}{l}0.01^{\star \star \star} \\
(0.000)\end{array}$ & $\begin{array}{l}0.01 * * \pi \\
0.000)\end{array}$ \\
\hline Technology (Low tech.=1, h. head) & & & & & & & & & & & & & $\begin{array}{l}(0.000) \\
0.01^{* * *}\end{array}$ & $\begin{array}{l}(0.000) \\
0.01^{\star \star *}\end{array}$ & $\begin{array}{l}(0.000) \\
0.01^{* *+}\end{array}$ \\
\hline Technology (Low tech. $=1$, h. head) & & & & & & & & & & & & & $\begin{array}{l}0.010 .000) \\
(0.000)\end{array}$ & $\begin{array}{l}0.01^{* 0 \times x} \\
(0.000)\end{array}$ & $\begin{array}{l}0.01^{* \pi \times} \\
(0.000)\end{array}$ \\
\hline Technology (High tech. $=1$, h. relative) & & & & & & & & & & & & & $0.02^{* \star * *}$ & $0.02^{\star \star \star *}$ & $0.02^{\star \star * \star}$ \\
\hline & & & & & & & & & & & & & $(0.000)$ & $(0.000)$ & $(0.000)$ \\
\hline Technology (Medium-high tech. $=1, \mathrm{~h}$. relative) & & & & & & & & & & & & & $0.02^{\star \star \star}$ & $0.02^{\star \star \star *}$ & $0.02^{*+*}$ \\
\hline & & & & & & & & & & & & & $(0.000)$ & $(0.000)$ & $(0.000)$ \\
\hline Technology (Medium-low tech. $=1$, h. relative) & & & & & & & & & & & & & $0.01^{\star \star *}$ & $0.01^{* \star \star}$ & $0.01^{* * * *}$ \\
\hline Technology (Low tech. $=1$, h. relative) & & & & & & & & & & & & & $\begin{array}{l}(0.000) \\
0.01^{\star \star \star}\end{array}$ & $\begin{array}{l}(0.000) \\
0.01^{\star \star \star}\end{array}$ & $\begin{array}{l}(0.000) \\
0.01^{\star \star \star}\end{array}$ \\
\hline & & & & & & & & & & & & & $(0.000)$ & $(0.000)$ & $(0.000)$ \\
\hline Constant & & & & $-0.37 * \star *$ & $-0.34^{4 * * x}$ & $-0.42^{2 * *}$ & & & & $-0.47^{\star \star *}$ & $-0.44^{\star \star \star}$ & $-0.53^{* \star *}$ & 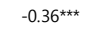 & $-0.34^{* \star *}$ & $-0.41^{\star \star \star *}$ \\
\hline & $(0.000)$ & $(0.000)$ & $(0.000)$ & $(0.000)$ & $(0.000)$ & $(0.000)$ & $(0.000)$ & $(0.000)$ & $(0.000)$ & $(0.000)$ & $(0.000)$ & $(0.000)$ & $(0.000)$ & $(0.000)$ & $(0.000)$ \\
\hline Observations (in millions) & 1,281 & 736 & 546 & 1,281 & 736 & 546 & 1,281 & 736 & 546 & 2,255 & 1,325 & 930 & 1,370 & 784 & 586 \\
\hline
\end{tabular}




\begin{tabular}{|c|c|c|c|c|c|c|c|c|c|c|c|c|c|c|c|}
\hline \multicolumn{16}{|c|}{$\begin{array}{l}\text { Appendix Table 6B. Household-Level Quantile Regressions on the Median (Standardized Coefficients) } \\
\text { Dependent Variable: Real Size-Adjusted Household Income Relative to the Annual State Median (1968-16) }\end{array}$} \\
\hline & $\begin{array}{c}(1) \\
\mathrm{Y}(\mathrm{h}) / \mathrm{Y} . \mathrm{Med} \\
\text { Full sample } \\
\mathrm{Q}(0.72) \\
\end{array}$ & $\begin{array}{c}(2) \\
Y(h) / \text { Y.Med } \\
1977-1999 \\
\text { Q(0.72) } \\
\end{array}$ & $\begin{array}{c}(3) \\
Y(h) / . M e d \\
2000-2015 \\
Q(0.72) \\
\end{array}$ & $\begin{array}{c}(4) \\
Y(\mathrm{~h}) / \mathrm{Y} . \text { Med } \\
\text { Full sample } \\
\mathrm{Q}(0.72) \\
\end{array}$ & $\begin{array}{c}\text { (5) } \\
Y(h) / . M e d \\
1977-1999 \\
Q(0.72) \\
\end{array}$ & $\begin{array}{c}(6) \\
Y(h) / Y . M e d \\
2000-2015 \\
Q(0.72) \\
\end{array}$ & $\begin{array}{c}(7) \\
Y(h) / . M e d \\
\text { Full sample } \\
Q(0.72) \\
\end{array}$ & $\begin{array}{c}(8) \\
Y(\mathrm{~h}) / \text { M.Med } \\
1977-1999 \\
Q(0.72) \\
\end{array}$ & $\begin{array}{c}9) \\
Y(h) / Y . M e d \\
2000-2015 \\
Q(0.72) \\
\end{array}$ & $\begin{array}{c}(10) \\
Y(h) / Y . M e d \\
\text { Full sample } \\
\text { Q(0.72) } \\
\end{array}$ & $\begin{array}{c}(11) \\
Y(h) / . M e d \\
1977-1999 \\
Q(0.72) \\
\end{array}$ & $\begin{array}{c}(12) \\
Y(h) / \text { Med } \\
2000-2015 \\
Q(0.72) \\
\end{array}$ & $\begin{array}{c}(13) \\
\mathrm{Y}(\mathrm{h}) / Y . M e d \\
\text { Full sample } \\
\mathrm{Q}(0.72) \\
\end{array}$ & $\begin{array}{c}(14) \\
Y(\text { h)/Y.Med } \\
1977-1999 \\
Q(0.72) \\
\end{array}$ & $\begin{array}{c}(15) \\
Y(h) / Y . M e d \\
2000-2015 \\
Q(0.72) \\
\end{array}$ \\
\hline Age & $\begin{array}{l}0.15^{*+* t} \\
(0.000)\end{array}$ & $\begin{array}{l}0.14^{*+*+1} \\
(0.000)\end{array}$ & $\begin{array}{l}0.16^{*+*+} \\
(0.000)\end{array}$ & $\begin{array}{l}0.16^{*+*+*} \\
(0.000)\end{array}$ & $\begin{array}{l}0.14^{*+*+*} \\
(0.000)\end{array}$ & $\begin{array}{l}0.17^{*+* *} \\
(0.000)\end{array}$ & $\begin{array}{l}0.15^{\text {t*t+ }} \\
(0.000)\end{array}$ & $\begin{array}{l}0.14^{* * *+} \\
(0.000)\end{array}$ & $\begin{array}{l}0.16^{*+*+} \\
(0.000)\end{array}$ & $\begin{array}{l}0.15^{* *+*} \\
(0.000)\end{array}$ & $\begin{array}{l}0.13^{*+* t} \\
(0.000)\end{array}$ & $\begin{array}{l}0.15^{\text {t**t}} \\
(0.000)\end{array}$ & $\begin{array}{l}0.16^{*+* *} \\
(0.000)\end{array}$ & $\begin{array}{l}0.15^{*+* t} \\
(0.000)\end{array}$ & $\begin{array}{l}0.17^{*+*+1} \\
(0.000)\end{array}$ \\
\hline Gender $($ male $=1)$ & $\begin{array}{l}0.14^{\star \star \star *} \\
(0.000)\end{array}$ & $\begin{array}{l}0.12^{\star \star \star *} \\
(0.000)\end{array}$ & $\begin{array}{l}0.13^{* * *} \\
(0.000)\end{array}$ & $\begin{array}{l}0.12^{* \star * *} \\
(0.000)\end{array}$ & $\begin{array}{l}0.10^{* * * *} \\
(0.000)\end{array}$ & $\begin{array}{l}0.12^{* * *} \\
(0.000)\end{array}$ & $\begin{array}{l}0.14^{\star \star \star *} \\
(0.000)\end{array}$ & $\begin{array}{l}0.12^{\star \star \star} \\
(0.000)\end{array}$ & $\begin{array}{l}0.13^{\star \star \star} \\
(0.000)\end{array}$ & $\begin{array}{l}0.09 * \star * \\
(0.000)\end{array}$ & $\begin{array}{l}0.07^{\star \star \star \star} \\
(0.000)\end{array}$ & $\begin{array}{l}0.09 * \star \star \\
(0.000)\end{array}$ & $\begin{array}{l}0.11^{\star \star \star} \\
(0.000)\end{array}$ & $\begin{array}{l}0.09^{\star \star \star} \\
(0.000)\end{array}$ & $\begin{array}{l}0.11^{\star \star \star *} \\
(0.000)\end{array}$ \\
\hline Education & $\begin{array}{l}0.19^{\star \star \star *} \\
(0.000)\end{array}$ & $\begin{array}{l}0.16^{* * *} \\
(0.000)\end{array}$ & $\begin{array}{l}0.31^{\star \star *} \\
(0.000)\end{array}$ & $\begin{array}{l}0.20^{* * *} \\
(0.000)\end{array}$ & $\begin{array}{l}0.17^{* * *} \\
(0.000)\end{array}$ & $\begin{array}{l}0.31^{\star \star *} \\
(0.000)\end{array}$ & $\begin{array}{l}0.18^{\star \star \star *} \\
(0.000)\end{array}$ & $\begin{array}{l}0.16^{\star \star *} \\
(0.000)\end{array}$ & $\begin{array}{l}0.29 * \star * \\
(0.000)\end{array}$ & $\begin{array}{l}0.22^{* * *} \\
(0.000)\end{array}$ & $\begin{array}{l}0.20^{\star * *} \\
(0.000)\end{array}$ & $\begin{array}{l}0.34^{\star \star *} \\
(0.000)\end{array}$ & $\begin{array}{l}0.22^{\star \star \star *} \\
(0.000)\end{array}$ & $\begin{array}{l}0.19 \star \star \star \\
(0.000)\end{array}$ & $\begin{array}{l}0.33^{*+*} \\
(0.000)\end{array}$ \\
\hline Share of non-white population & $\begin{array}{c}-0.03^{* * * *} \\
(0.000)\end{array}$ & $\begin{array}{c}-0.04^{* * *} \\
(0.000)\end{array}$ & $\begin{array}{c}-0.03^{* * * *} \\
(0.000)\end{array}$ & $\begin{array}{c}-0.03^{* * * *} \\
(0.000)\end{array}$ & $\begin{array}{c}-0.04^{* \star * \star} \\
(0.000)\end{array}$ & $\begin{array}{l}-0.03^{* \star *} \\
(0.000)\end{array}$ & $\begin{array}{l}-0.03^{* \star *} \\
(0.000)\end{array}$ & $\begin{array}{l}-0.04^{* \star *} \\
(0.000)\end{array}$ & $\begin{array}{l}-0.03^{* \star *} \\
(0.000)\end{array}$ & $\begin{array}{l}-0.04^{\star \star \star} \\
(0.000)\end{array}$ & $\begin{array}{c}-0.03^{* \star *} \\
(0.000)\end{array}$ & $\begin{array}{l}-0.04^{\star * \star} \\
(0.000)\end{array}$ & $\begin{array}{c}-0.03^{* * *} \\
(0.000)\end{array}$ & $\begin{array}{l}-0.04^{* \star *} \\
(0.000)\end{array}$ & $\begin{array}{l}-0.03^{* * *} \\
(0.000)\end{array}$ \\
\hline Age (h. relative) & $\begin{array}{l}0.14^{\star \star \star} \\
(0.000)\end{array}$ & $\begin{array}{l}0.15^{\star \star *} \\
(0.000)\end{array}$ & $\begin{array}{l}0.15^{* \star *} \\
(0.000)\end{array}$ & $\begin{array}{l}0.14^{* * *} \\
(0.000)\end{array}$ & $\begin{array}{l}0.15^{* * *} \\
(0.000)\end{array}$ & $\begin{array}{l}0.14^{\star \star \star} \\
(0.000)\end{array}$ & $\begin{array}{l}0.14^{\star \star \star} \\
(0.000)\end{array}$ & $\begin{array}{l}0.15^{\star \star \star} \\
(0.000)\end{array}$ & $\begin{array}{l}0.14^{\star \star \star} \\
(0.000)\end{array}$ & $\begin{array}{l}0.13^{* \star *} \\
(0.000)\end{array}$ & $\begin{array}{l}0.15^{* \star \star} \\
(0.000)\end{array}$ & $\begin{array}{l}0.11^{\star \star \star} \\
(0.000)\end{array}$ & $\begin{array}{l}0.14^{\star \star \star} \\
(0.000)\end{array}$ & $\begin{array}{l}0.15^{\star \star \star} \\
(0.000)\end{array}$ & $\begin{array}{l}0.14^{\star \star * *} \\
(0.000)\end{array}$ \\
\hline Gender (male = 1) (h. relative) & $\begin{array}{l}0.11^{\star \star \star} \\
(0.000)\end{array}$ & $\begin{array}{l}0.12^{\star \star \star *} \\
(0.000)\end{array}$ & $\begin{array}{l}0.10^{*+*} \\
(0.000)\end{array}$ & $\begin{array}{l}0.09^{* * *} \\
(0.000)\end{array}$ & $\begin{array}{l}0.10^{\star \star \star *} \\
(0.000)\end{array}$ & $\begin{array}{l}0.09^{\star \star \star *} \\
(0.000)\end{array}$ & $\begin{array}{l}0.10^{* \star * *} \\
(0.000)\end{array}$ & $\begin{array}{l}0.11^{\star \star \star} \\
(0.000)\end{array}$ & $\begin{array}{l}0.10^{* \star *} \\
(0.000)\end{array}$ & $\begin{array}{l}0.05^{\star \star \star} \\
(0.000)\end{array}$ & $\begin{array}{l}0.07^{\star \star \star *} \\
(0.000)\end{array}$ & $\begin{array}{l}0.06^{* \star \star *} \\
(0.000)\end{array}$ & $\begin{array}{l}0.08^{\star \star \star \star} \\
(0.000)\end{array}$ & $\begin{array}{l}0.09^{\star \star \star} \\
(0.000)\end{array}$ & $\begin{array}{l}0.08^{* * *} \\
(0.000)\end{array}$ \\
\hline Education (h. relative) & $\begin{array}{l}0.20^{\star * * *} \\
(0.000)\end{array}$ & $\begin{array}{l}0.18^{\star * *} \\
(0.000)\end{array}$ & $\begin{array}{l}0.27^{* \star * *} \\
(0.000)\end{array}$ & $\begin{array}{l}0.21^{* \star * *} \\
(0.000)\end{array}$ & $\begin{array}{l}0.18^{\star \star \star *} \\
(0.000)\end{array}$ & $\begin{array}{l}0.27 * \star \star \\
(0.000)\end{array}$ & $\begin{array}{l}0.20^{\star \star \star *} \\
(0.000)\end{array}$ & $\begin{array}{l}0.18^{\star \star \star \star} \\
(0.000)\end{array}$ & $\begin{array}{l}0.26^{* * *} \\
(0.000)\end{array}$ & $\begin{array}{l}0.19 * \star * \\
(0.000)\end{array}$ & $\begin{array}{l}0.16^{* * *} \\
(0.000)\end{array}$ & $\begin{array}{l}0.27 * \star \star \star * t \\
(0.000)\end{array}$ & $\begin{array}{l}0.22^{* \star \star *} \\
(0.000)\end{array}$ & $\begin{array}{l}0.19 \star \star \star \\
(0.000)\end{array}$ & $\begin{array}{l}0.29 * * * \\
(0.000)\end{array}$ \\
\hline Share of non-white population (h. relative) & $\begin{array}{l}-0.02^{2 * *} \\
(0.000)\end{array}$ & $\begin{array}{l}-0.02^{2 *+*} \\
(0.000)\end{array}$ & $\begin{array}{l}-0.00^{2+*+} \\
(0.000)\end{array}$ & $\begin{array}{l}-0.02^{2 * \star *} \\
(0.000)\end{array}$ & $\begin{array}{l}-0.02^{2+* *} \\
(0.000)\end{array}$ & $\begin{array}{l}-0.02^{* \star * \pi} \\
(0.000)\end{array}$ & $\begin{array}{l}-0.02^{2 *+*} \\
(0.000)\end{array}$ & $\begin{array}{l}-0.02^{* \star \star} \\
(0.000)\end{array}$ & $\begin{array}{l}-0.02+* \star \\
(0.000)\end{array}$ & $\begin{array}{l}-0.02^{* \star \star} \\
(0.000)\end{array}$ & $\begin{array}{l}-0.00^{3+k x} \\
(0.000)\end{array}$ & $\begin{array}{l}-0.02+2 * * \\
(0.000)\end{array}$ & $\begin{array}{l}-0.02+* \star \\
(0.000)\end{array}$ & $\begin{array}{l}-0.00^{2 * *} \\
(0.000)\end{array}$ & $\begin{array}{c}-0.02^{2+*} \\
(0.000)\end{array}$ \\
\hline Offshorability score & $\begin{array}{l}-0.07 * * * \\
(0.000)\end{array}$ & $\begin{array}{l}-0.07 * * x \\
(0.000)\end{array}$ & $\begin{array}{l}-0.07 * x+x \\
(0.000)\end{array}$ & & & & $\begin{array}{l}-0.00^{* * *} \\
(0.000)\end{array}$ & $\begin{array}{c}-0.06^{* * *} \\
(0.000)\end{array}$ & $\begin{array}{l}-0.066 * x \\
(0.000)\end{array}$ & & & & & & \\
\hline Offshorability score (h. relative) & $\begin{array}{l}-0.06^{* \star *} \\
(0.000)\end{array}$ & $\begin{array}{l}-0.05^{* * *} \\
(0.000)\end{array}$ & $\begin{array}{l}-0.06^{* \star \star} \\
(0.000)\end{array}$ & & & & $\begin{array}{l}-0.05^{* \star *} \\
(0.000)\end{array}$ & $\begin{array}{l}-0.05^{* \star *} \\
(0.000)\end{array}$ & $\begin{array}{l}-0.05^{* * *} \\
(0.000)\end{array}$ & & & & & & \\
\hline Routinization score & & & & $\begin{array}{c}-0.04 * \star \star \\
(0.000)\end{array}$ & $\begin{array}{c}-0.04 * \star * \\
(0.000)\end{array}$ & $\begin{array}{l}-0.04 \star \star \star \\
(0.000)\end{array}$ & $\begin{array}{l}-0.03^{* \star *} \\
(0.000)\end{array}$ & $\begin{array}{l}-0.03^{* \star *} \\
(0.000)\end{array}$ & $\begin{array}{c}-0.04 *+* \\
(0.000)\end{array}$ & & & & & & \\
\hline Routinization score (h. relative) & & & & $\begin{array}{c}-0.00 * * * \\
(0.000)\end{array}$ & $\begin{array}{l}0.01^{* * *} \\
(0.000)\end{array}$ & $\begin{array}{c}-0.03^{\star \star * *} \\
(0.000)\end{array}$ & $\begin{array}{c}-0.00 * \star * \\
(0.000)\end{array}$ & $\begin{array}{l}0.01^{1 * \star} \\
(0.000)\end{array}$ & $\begin{array}{c}-0.03^{* * *} \\
(0.000)\end{array}$ & & & & & & \\
\hline Manufacturing (=1) & & & & & & & & & & $\begin{array}{l}0.03^{* * *} \\
(0.000)\end{array}$ & $\begin{array}{l}0.02^{*+*} \\
(0.000)\end{array}$ & $\begin{array}{l}0.03^{*+*} \\
(0.000)\end{array}$ & & & \\
\hline Manufacturing $(=1)$ (h. relative) & & & & & & & & & & $\begin{array}{l}0.05^{* * *} \\
(0.000)\end{array}$ & $\begin{array}{l}0.05^{* \star * *} \\
(0.000)\end{array}$ & $\begin{array}{l}0.03^{* \star \star} \\
(0.000)\end{array}$ & & & \\
\hline Technology (High tech. $=1$, h. head) & & & & & & & & & & & & & $\begin{array}{l}0.02^{\star \star \star *} \\
(0.000)\end{array}$ & $\begin{array}{l}0.02^{\star \star \star *} \\
(0.000)\end{array}$ & $\begin{array}{l}0.03^{* * *} \\
(0.000)\end{array}$ \\
\hline Technology (Medium-high tech. $=1, \mathrm{~h}$. head) & & & & & & & & & & & & & $\begin{array}{l}0.02^{\star \star \star *} \\
(0.000)\end{array}$ & $\begin{array}{l}0.02^{\star \star \star} \\
(0.000)\end{array}$ & $\begin{array}{l}0.02^{* * *} \\
(0.000)\end{array}$ \\
\hline Technology (Medium-low tech.=1, h. head) & & & & & & & & & & & & & $\begin{array}{l}0.00^{* * *} \\
(0.000\end{array}$ & $\begin{array}{l}0.01^{\star \star \star} \\
(0.000\end{array}$ & $\begin{array}{l}-0.00^{*+*} \\
(0.000)\end{array}$ \\
\hline Technology (Low tech. $=1$, h. head) & & & & & & & & & & & & & $\begin{array}{l}(0.000) \\
0.01 * \star \\
(0.000)\end{array}$ & $\begin{array}{l}(0.000) \\
0.01^{\star \star \star} \\
(0.000)\end{array}$ & $\begin{array}{l}(0.000) \\
-0.01^{* \star *} \\
(0.000)\end{array}$ \\
\hline Technology (High tech. $=1$, h. relative) & & & & & & & & & & & & & $\begin{array}{l}0.00^{+* t *} \\
(0.000)\end{array}$ & $\begin{array}{l}0.03^{\text {t*t* }} \\
(0.000)\end{array}$ & $\begin{array}{l}0.02^{+*+1} \\
(0.000)\end{array}$ \\
\hline Technology (Medium-high tech. $=1$, h. relative) & & & & & & & & & & & & & $0.03^{* \star *}$ & $0.03^{\star \star \star}$ & $0.01^{\star \star * *}$ \\
\hline Technology (Medium-low tech. $=1$, h. relative) & & & & & & & & & & & & & $\begin{array}{l}(0.000) \\
0.01^{\text {t** }}\end{array}$ & $\begin{array}{l}(0.000) \\
0.01^{\star \star \star}\end{array}$ & $\begin{array}{l}(0.000) \\
0.00\end{array}$ \\
\hline & & & & & & & & & & & & & $(0.000)$ & $(0.000)$ & $(0.000)$ \\
\hline Technology (Low tech.=1, h. relative) & & & & & & & & & & & & & $\begin{array}{l}0.02^{\star \star \star} \\
(0.000)\end{array}$ & $\begin{array}{l}0.02^{\star \star \star} \\
(0.000)\end{array}$ & $\begin{array}{l}0.00^{* * *} \\
(0.000)\end{array}$ \\
\hline Constant & $\begin{array}{l}0.37^{\star \star * *} \\
(0.000)\end{array}$ & $\begin{array}{l}0.39 \star \star \star \\
(0.000)\end{array}$ & $\begin{array}{l}0.27 * * * \\
(0.000)\end{array}$ & $\begin{array}{l}0.37^{\star \star * *} \\
(0.000)\end{array}$ & $\begin{array}{l}0.40^{\star \star \star \star} \\
(0.000)\end{array}$ & $\begin{array}{l}0.27^{\star \star \star} \\
(0.000)\end{array}$ & $\begin{array}{l}0.37^{* * *} \\
(0.000)\end{array}$ & $\begin{array}{l}0.40^{*+*+*} \\
(0.000)\end{array}$ & $\begin{array}{l}0.27 * *+* \\
(0.000)\end{array}$ & $\begin{array}{l}0.26^{* * * *} \\
(0.000)\end{array}$ & $\begin{array}{l}0.28^{*+* t} \\
(0.000)\end{array}$ & $\begin{array}{l}0.17+* * * \\
(0.000)\end{array}$ & $\begin{array}{l}0.37^{+40 * t} \\
(0.000)\end{array}$ & $\begin{array}{l}0.39+* * * \\
(0.000)\end{array}$ & $\begin{array}{l}0.27^{*+*+} \\
(0.000)\end{array}$ \\
\hline Observations (in millions) & 1,281 & 736 & 546 & 1,281 & 736 & 546 & 1,281 & 736 & 546 & 2,255 & 1,325 & 930 & 1,370 & 784 & 586 \\
\hline
\end{tabular}

